\title{
National Emission Standards for Hazardous Air Pollutants Application for Approval to Stabilize the $105 \mathrm{~N}$ Basin
}

Prepared for the U.S. Department of Energy Office of Environmental Restoration and Waste Management

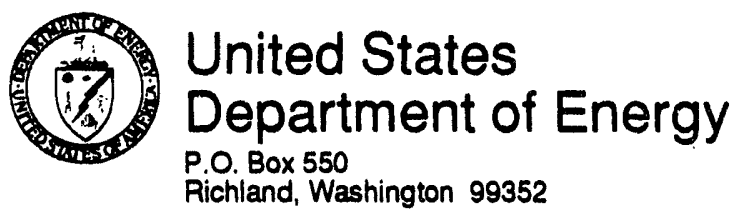

Approved for Public Release 
1.0 INTRODUCTION ...................... . . . . . . . . . .

1.1 DESCRIPTION OF FACILITY . . . . . . . . . . . 1-1

2.0 NATURE OF SOURCE . . . . . . . . . . . . 2-1

2.1 DESCRIPTION OF ACTIVITIES ............. 2-1

2.1.1 Underwater Activities . . . . . . . . . . 2-8

2.1.2 Above Water Activities ........... 2-12

2.2 DESCRIPTION OF THE 105N BASIN INVENTORY .......

2.2.1 Radionuclide Sources............ 2-15

2.2.2 Radionuclide Inventory of 105N Basin....... 2-15

3.0 EMISSIONS CONTROL SYSTEM . . . . . . . . . . . . . . 3-1

3.1 EFFLUENT SYSTEM LAYOUT . . . . . . . . . . . . . . 3-1

3.2 EMISSIONS RELEASE RATES .............. 3-4

3.2.1 Chemical and Physical Forms of Releases ...... 3-4

3.2.2 Good Engineering Judgement Emissions Estimate : . 3-4

3.2.3 40 CFR 61, Appendix D, Methodology ......... 3-11

3.3 OFFSITE DOSES . . . . . . . . . . . . . 3-15

3.3.1 Input Data Used . . . . . . . . . . . . . 3-15

3.3 .2 Results ................. 3-15

4.0 REFERENCES ..................... . . . . .

\section{APPENDICES}

A-1 CORRESPONDENCE - $N$ REACTOR EFFLUENT PROJECTION . . . . . A APP A-1-i

A-2 CORRESPONDENCE - UNDERWATER PLASMA CUTTING . . . . . . APP A-2-i

A-3 CORRESPONDENCE - 10ON FUEL CANISTER ASSAYS . . . . . APP A-3-i

A-4 EFFECTS OF HYDROSCRUBBING ...................... APP A-4-i

B THERMAL EVALUATION OF PLASMA TORCH CUTTING ......... APP B-i

C CAP-88 RESULTS 105N BASIN STABILIZATION .......... APP $\mathrm{C}-\mathrm{i}$ 


\section{LIST OF FIGURES}

1-1 Location of 100N Area . . . . . . . . . . . . . . 1-3

1-2 Regional Location of the $100 \mathrm{~N}$ Area ............. 1-4

1-3 Map of the 105N Basin Complex ............. . 1-5

2-1 Sand Filter and Remotely Operated Sediment Extraction

Equipment System Configuration............ 2-3

2-2 Location of 105N Basin Air Sampling Instrumentation . . . . . 2-4

2-3 Remotely Operated Sediment Extraction Equipment System Configuration .................. 2-10

2-4 High Level Radioactive Material Flow Diagram . . . . . . . . 2-13

3-1 Simplified Sketch 105N Basin/Transfer Area Air Space . . . . . . 3-2

3-2 Airflow Configuration Through the 117N High-Efficiency Particulate Air Filter Building ........... 3-3

\section{LIST OF TABLES}

2-1 105N Basin Radionuclide Inventory ........... 2-17

2-2 Hardware Inventory to be Removed from 105N Basin ....... 2-18

3-1 Emissions from Debris Handling and Removal . . . . . . . . . . 3-7

3-2 Emissions from Plasma Torch Cutting . . . . . . . . . . 3-10

3-3 Emissions from Hydroscrubbing ............. 3-12

3-4 Emissions Results Based on Good Engineering Judgement . . . . . 3-13

3-5 Projected Annual Emissions Results Based on 40 CFR 61 Methodology ............... 3-14

3-6 Effective Dose Equivalent to Individual Receiving Maximum Exposure to Radiological Emissions Based on Good Engineering Judgement ............... 3-16

3-7 Effective Dose Equivalent to Individual Receiving Maximum Exposure to Radiological Emissions ............. 3-18 
DOE/RL-94-15, Rev. 0

\section{ACRONYMS}

ALARA

bas in

CAM

CAP-88

CFR

DAC

DOE

DOT

EDE

EPA

GEJ

HEPA

IXM

MEI

PAPR

PNL

ROSEE

SNM

As Low As Reasonably Achievable

$1 C$..1 Basin

continuous air monitors

Clean Air Assessment Package 1988

Code of Federal Regulations

derived air concentration

U.S. Department of Energy

U.S. Department of Transportation

effective dose equivalent

U.S. Environmental Protection Agency

good engineering judgement

high-efficiency particulate air

Ion Exchange Modules

maximally exposed individual

powered air purifying respirator

Pacific Northwest Laboratory

Remotely Operated Sediment Extraction Equipment

Special Nuclear Material 


\section{METRIC CONVERSION CHART}

The following conversion chart is provided to the reader to aid in conversion.

Into metric units

Out of metric units

\begin{tabular}{|c|c|c|c|c|c|}
\hline If you know & $\begin{array}{c}\text { Multiply } \\
\text { by }\end{array}$ & To get & If you know & $\begin{array}{l}\text { Multiply } \\
\text { by }\end{array}$ & To get \\
\hline \multicolumn{3}{|c|}{ Length } & \multicolumn{3}{|c|}{ Length } \\
\hline inches & 25.40 & millimeters & millimeters & 0.0393 & inches \\
\hline inches & 2.54 & centimeters & centimeters & 0.393 & inches \\
\hline feet & 0.3048 & meters & meters & 3.2808 & feet \\
\hline yards & 0.914 & meters & meters & 1.09 & yards \\
\hline miles & 1.609 & kilometers & kilometers & 0.62 & miles \\
\hline \multicolumn{3}{|c|}{ Area } & \multicolumn{3}{|c|}{ Area } \\
\hline $\begin{array}{l}\text { square } \\
\text { inches }\end{array}$ & 6.4516 & $\begin{array}{l}\text { square } \\
\text { centimeters }\end{array}$ & $\begin{array}{l}\text { square } \\
\text { cent imeters }\end{array}$ & 0.155 & $\begin{array}{l}\text { square } \\
\text { inches }\end{array}$ \\
\hline square feet & 0.092 & $\begin{array}{l}\text { square } \\
\text { meters }\end{array}$ & $\begin{array}{l}\text { square } \\
\text { meters }\end{array}$ & 10.7639 & $\begin{array}{l}\text { square } \\
\text { feet }\end{array}$ \\
\hline $\begin{array}{l}\text { square } \\
\text { yards }\end{array}$ & 0.836 & $\begin{array}{l}\text { square } \\
\text { meters }\end{array}$ & $\begin{array}{l}\text { square } \\
\text { meters }\end{array}$ & 1.20 & $\begin{array}{l}\text { square } \\
\text { yards }\end{array}$ \\
\hline $\begin{array}{l}\text { square } \\
\text { miles }\end{array}$ & 2.59 & $\begin{array}{l}\text { square } \\
\text { kilometers }\end{array}$ & $\begin{array}{l}\text { square } \\
\text { kilometers }\end{array}$ & 0.39 & $\begin{array}{l}\text { square } \\
\text { miles }\end{array}$ \\
\hline acres & 0.404 & hectares & hectares & 2.471 & acres \\
\hline \multicolumn{3}{|c|}{ Mass (weight) } & \multicolumn{3}{|c|}{ Mass (weight) } \\
\hline ounces & 28.35 & grams & grams & 0.0352 & ounces \\
\hline pounds & 0.453 & kilograms & kilograms & 2.2046 & pounds \\
\hline short ton & 0.907 & metric ton & metric ton & 1.10 & short ton \\
\hline \multicolumn{3}{|c|}{ Volume } & \multicolumn{3}{|c|}{ Volume } \\
\hline $\begin{array}{l}\text { fluid } \\
\text { ounces } \\
\end{array}$ & 29.57 & milliliters & milliliters & 0.03 & $\begin{array}{l}\text { fluid } \\
\text { ounces }\end{array}$ \\
\hline quarts & 0.95 & Titers & Titers & 1.057 & quarts \\
\hline gallons & 3.79 & Titers & Titers & 0.26 & gallons \\
\hline cubic feet & 0.03 & $\begin{array}{l}\text { cubic } \\
\text { meters }\end{array}$ & $\begin{array}{l}\text { cubic } \\
\text { meters }\end{array}$ & 35.3147 & cubic feet \\
\hline cubic yards & 0.76 & $\begin{array}{l}\text { cubic } \\
\text { meters }\end{array}$ & $\begin{array}{l}\text { cubic } \\
\text { meters }\end{array}$ & 1.308 & $\begin{array}{l}\text { cubic } \\
\text { yards }\end{array}$ \\
\hline \multicolumn{3}{|c|}{ Temperature } & \multicolumn{3}{|c|}{ Temperature } \\
\hline Fahrenheit & $\begin{array}{l}\text { subtract } \\
32 \text { then } \\
\text { multiply } \\
\text { by } 5 / 9 \text { ths }\end{array}$ & Celsius & Celsius & $\begin{array}{l}\text { multiply } \\
\text { by } \\
9 / 5 \text { ths, } \\
\text { then add } \\
32\end{array}$ & Fahrenheit \\
\hline
\end{tabular}

Source: Engineering Unit Conversions, M. R. Lindeburg, PE., Second Ed., 1990, Professional Publications, Inc., Belmont, California. 
MATIONAL EMISSION STANDARDS FOR HAZARDOUS AIR POLLUTANTS APPLICATION FOR APPROVAL TO STABILIZE THE 105N BASIN

\subsection{INTRODUCTION}

The 105N Basin (basin) Stabilization will place the basin in a radiologically and environmentally safe condition so that it can be decommissioned at a later date. The basin stabilization objectives are to inspect for Special Nuclear Material (SNM) (i.e., fuel assemblies and fuel pieces), remove the water from the basin and associated pits, and stabilize the basin surface. The stabilization will involve removal of bas in hardware, removal of basin sediments, draining of basin water, and cleaning and stabilizing basin surfaces to prevent resuspension of radioactive emissions to the air. These activities will be conducted in accordance with all applicable regulations.

\subsection{DESCRIPTION OF FACILITY}

The basin is in the $105 \mathrm{~N}$ Building, which is located in the $100 \mathrm{~N}$ Area (Figure 1-1). The $100 \mathrm{~N}$ Area is located in the Northern portion of the Hanford Site approximately 35 miles northwest of the city of Richland, Washington (Figure 1-2).

The basin is a reinforced unlined concrete structure 150 feet long, 50 feet wide, and 24 feet deep. The basin is segregated into seven areas sharing a common pool of water; the Discharge/Viewing ("D") Pit, the fuel segregation pit (including a water tunnel that connects the "D" pit and segregation pit), two storage basins designated as North Basin and South Basin, two cask load-out pits, and a fuel examination area. Figure 1-3 shows a map of the basin complex. The North Basin floor is entirely covered and the South Basin is partly covered by a modular array of cubicles formed by boron concrete posts and boron concrete panels. Normal water depth for the bas in is 23 feet, 5 inches.

Two ancillary facilities, the charge "C" Elevator Pit, and a water Lift Station are associated with the basin but are separate from the fuel storage water pool (Figure 1-3). Currently, approximately 12 feet of water exists in the "C" Elevator Pit. The Lift Station is located underground and north of the North Basin. The Lift Station pump well serves as a collection and segregation point for waste water from the $105 \mathrm{~N}$ Reactor building equipment and interior space drain system. During stabilization activities, water from piping, sumps, and the "C" Elevator Pit will be routed to the Lift Station. Water in the lift Station and the basin will be removed for processing and disposition el sewhere on the Hanford Site. Hardware and sediment from the "C" Elevator Pit will not be removed as part of stabilization activities because of As Low As Reasonably Achievable (ALARA) concerns. The $C$ Pit is contained within that part of the $105 \mathrm{~N}$ Building that houses the reactor core and will be part of future decommissioning activities. Additionally, no other stabilization activities associated with the Lift Station will be performed because of ALARA concerns. 
DOE/RL-94-15, Rev. 0

This page intentionally left blank. 


\section{N Reactor Facilities}

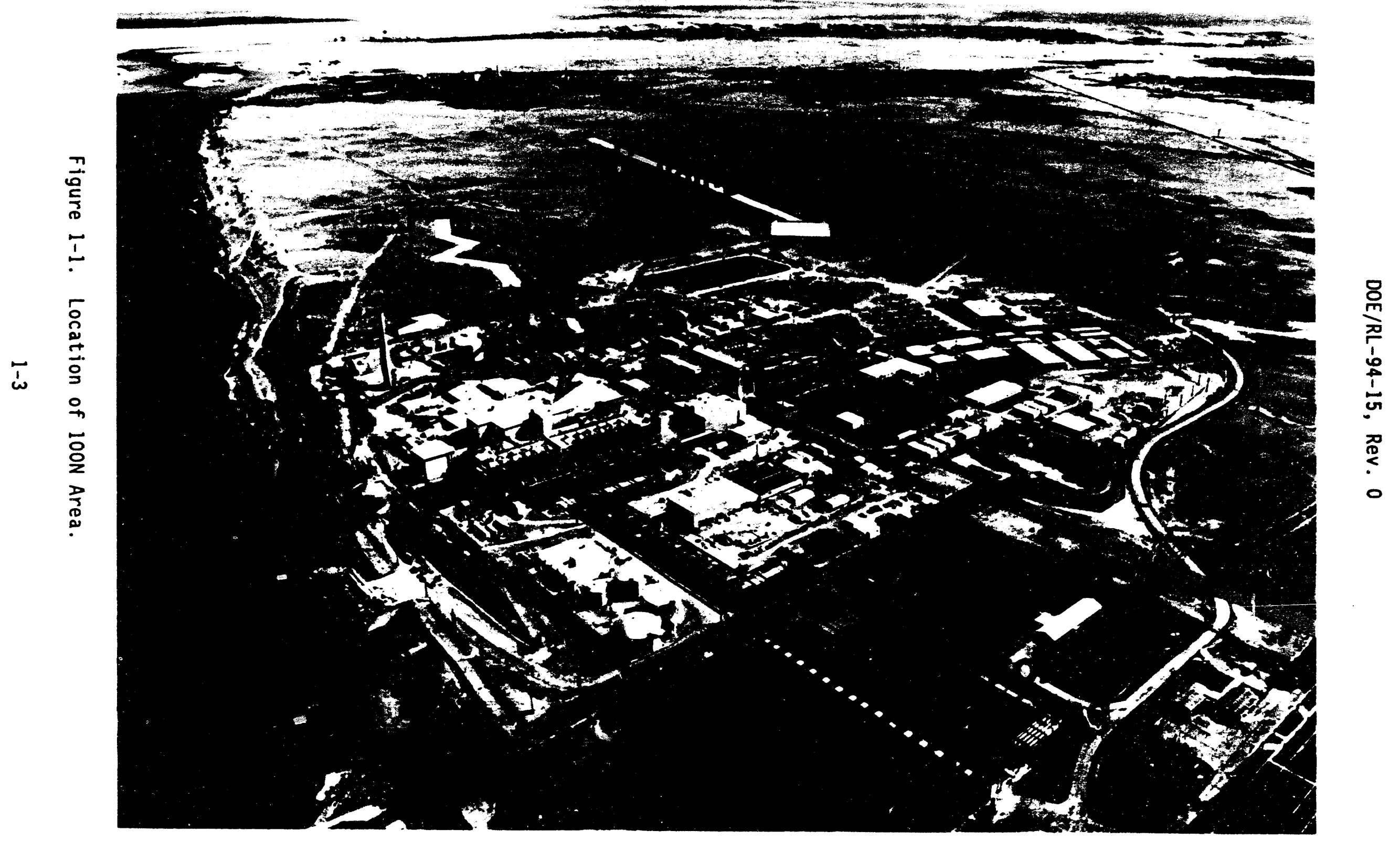


DOE/RL-94-15, Rev. 0

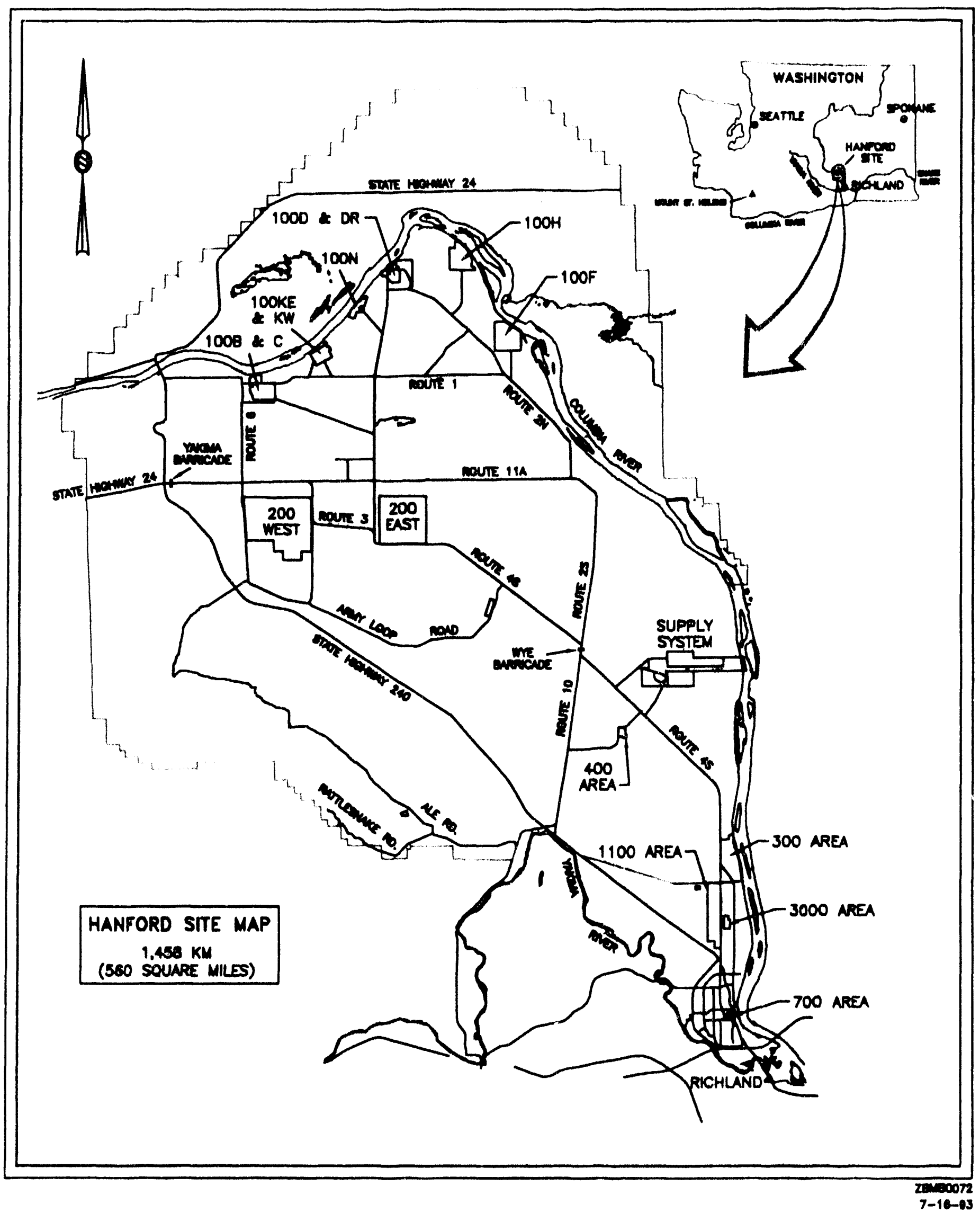

Figure 1-2. Regional Location of the 100N Area. 


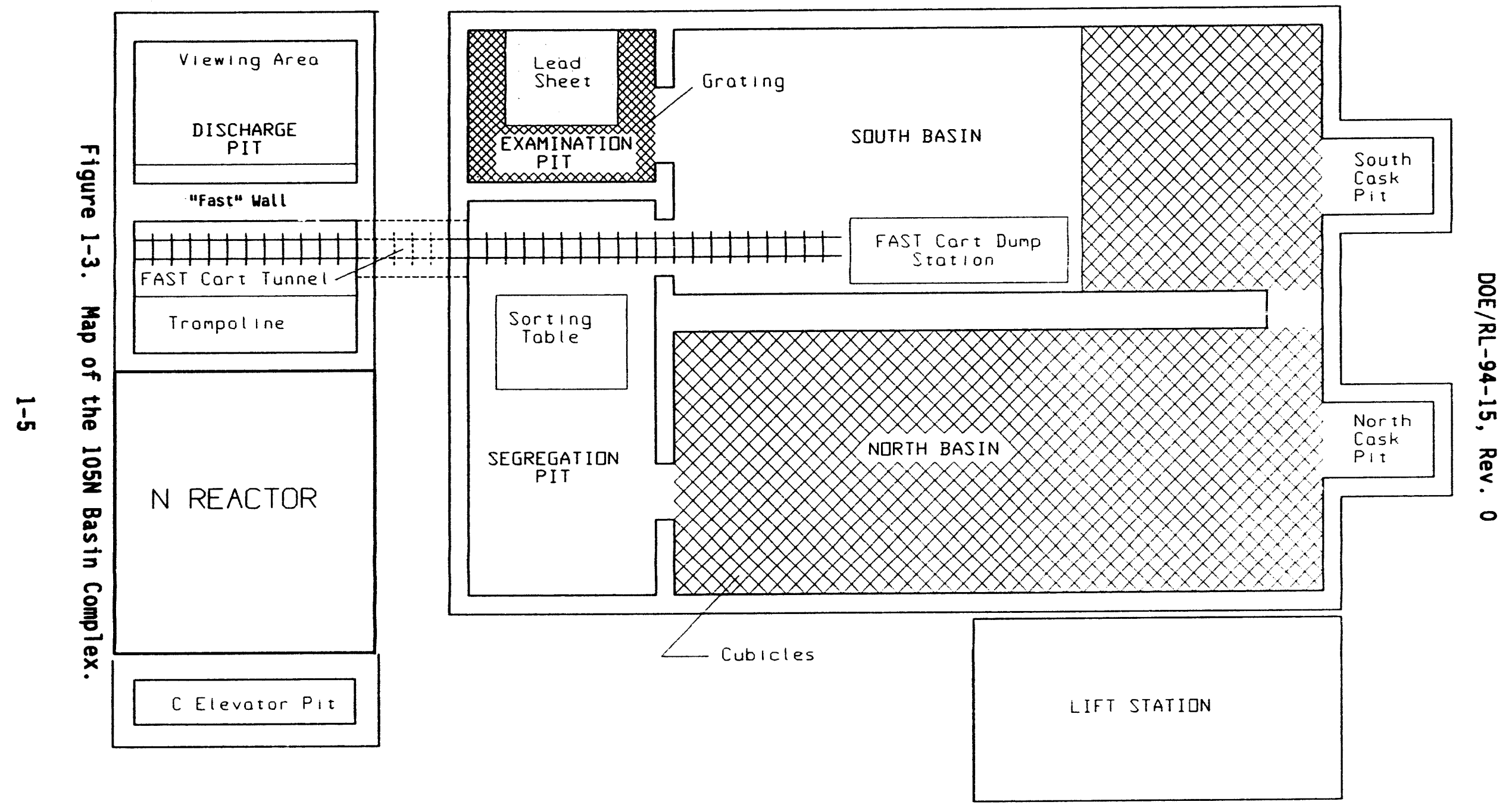




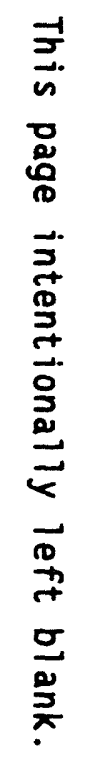




\subsection{MATURE OF SOURCE}

\subsection{DESCRIPTION OF ACTIVITIES} follows:

The basin stabilization has been divided into seven tasks listed as

- Task 1 - North Cast Pit

- Task 2 - South Cask Pit

- Task 3 - North Basin

- Task 4 - South Basin

- Task 5 - Examination Pit

- Task 6 - Segregation Pit

- Task 7 - Discharge Pit.

Each task will be completed by performing specific activities that are described in general below. All or portions of several activities may be conducted simultaneously. Sections 2.1 .1 and 2.1 .2 provide available detalls regarding the activities required to stabilize the basin.

The general approach under each task is to first hydroscrub the basin walls along the water line. The purpose of this activity is to reduce personnel exposure in the work area. When this activity is complete, personnel will start sediment removal with the Remotely Operated Sediment Extraction Equipment (ROSEE) system in conjunction with hardware and debris removal. ROSEE is a system that will vacuum the sediment through a cyclone separator for discharge into the North Cask Pit. Objects that cannot be removed with the ROSEE system (i.e., size limitations) will be sorted by dose rate. This sorting will be accomplished using a submerged radiation detection instrument.

Most of the waste generated during the basin cleanup activities is expected to be low-level radioactive waste. This waste includes cubicle lids, canisters, and fuel baskeis. Two alternatives have been identified for disposal of low-level radioactive waste. The alternatives are to bury the low level waste in approved burial containers on the Hanford Site, or transport the waste to a U.S. Department of Energy (DOE)-approved smelter for volume reduction. Volume reduction for the burial option will include crushing the canisters and possible cutting of the fuel baskets.

The preferred alternative is to ship the large quantity of contaminated metal to a DOE-approved smelter for volume reduction. In this case, the canisters will not be crushed, nor will the fuel baskets be cut into smaller pieces. Instead, the canisters, baskets, and other metal items will be placed in vendor-supplied containers and shipped to the smelting facility. At the smelting facility, the molten metal will be separated from the slag, which will contain the majority of the contamination. The metal will be retained at the smelting facility and the slag will be returned to the Hanford Site for burial. It is anticipated that for every 100 pounds of metal waste delivered to the smelting facility, 1 pound of slag waste will be returned to the Hanford Site Repository for burial as radioactive waste. 


$$
\text { DOE/RL-94-15, Rev. } 0
$$

Depending upon the task, other activities may be performed concurrently with sediment removal and hardware movement and removal. These activities might be underwater cutting (plasma arc), mechanical shearing, canister cleaning, and canister crushing. When ail material, hardware, and debris are removed from the basin, the basin areas will be vacuumed again by the ROSEE system. Concurrent with vacuum activities, each section of the basin will be inspected with remote radiation detection instrumentation and underwater video equipment to certify that all SNM has been removed from the basin. When SNM certification is complete, the basin will be ready for stabilization (i.e., water removal and surface sealing).

A sand filter will be installed in the basin with Ion Exchange Module(s) (IXM) on the outlet. The purpose of this system is to recirculate the basin water to maintain water clarity and reduce occupational radiation exposure. This will be a continuously running system with a flow of 700 gallons per minute. Capabilities for back-flushing the sand filter will be valved into the system. A line coming off the outlet of the IXMs will be used to supply the high-pressure wash station. Figure 2-1 presents a line diagram of the system components. In addition, the overflow from the ROSEE system cyclone separators will be valved into the inlet of the sand filter.

In general, the basin contamination level in the personnel work areas will be kept below 10,000 disintegrations per minute/100 square centimeters beta/gamma, and below 500 disintegrations per minute/100 square centimeters alpha. While these levels may be exceeded for specific localized activities, each specific job performed during the basin stabilization activities will be evaluated and contamination levels will be established based on the criteria set forth in the WHC-CM-1-6 Radiation Control Manual requirements. All activities are held to ALARA. Upon completion of each job or as conditions dictate, the basin area will be cleaned to below the contamination levels established prior to the job.

Full mask protection will be worn at $1 / 10$ of a derived air concentration (DAC) based on Pu-239 and Sr-90, the most limiting isotope of concern. It is anticipated that some activities may require this type of protection. At 5 DAC, based upon the most limiting isotopes, a powered air purifying respirator (PAPR) is required for respiratory protection. It is not expected that any stabilization activities will require a PAPR. Fixed head continuous air samplers are currently installed at specific locations in the basin (Figure 2-2) and will be kept in service for the duration of the basin deactivation project. In addition, a portable fixed head sampler will be set up in each work location in accordance with WHC-CM-1-6 (WHC 1993C). Grab air samples will be taken when respiratory protection is worn to verify the adequacy of protection. Alpha and beta continuous air monitors (CAM) will be running in the basin at all times while work is being performed in the basin area. Figure 2-2 shows the locations of air sampling and monitoring devices.

The following section provides specific descriptions of the tasks in sequential order. 


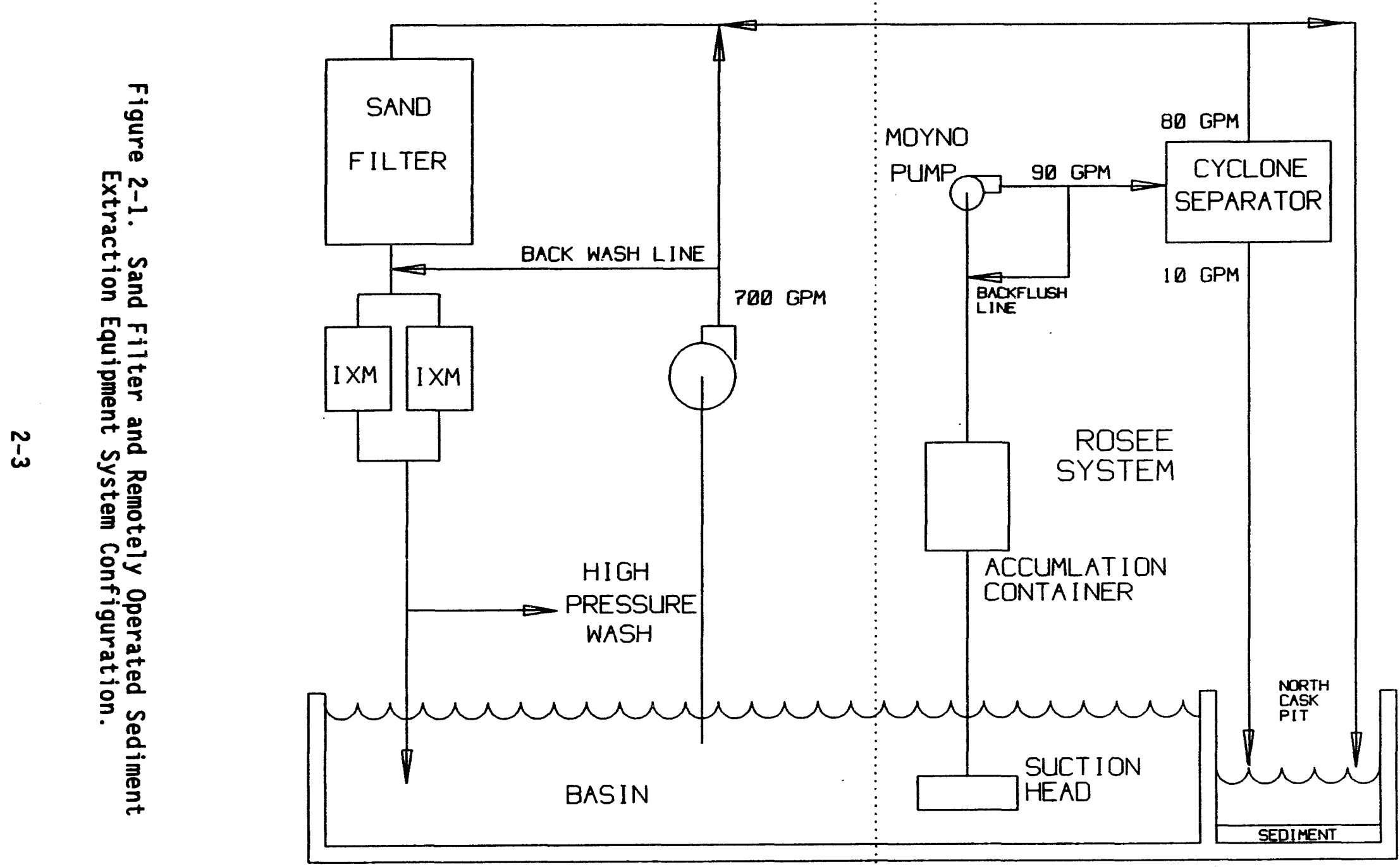




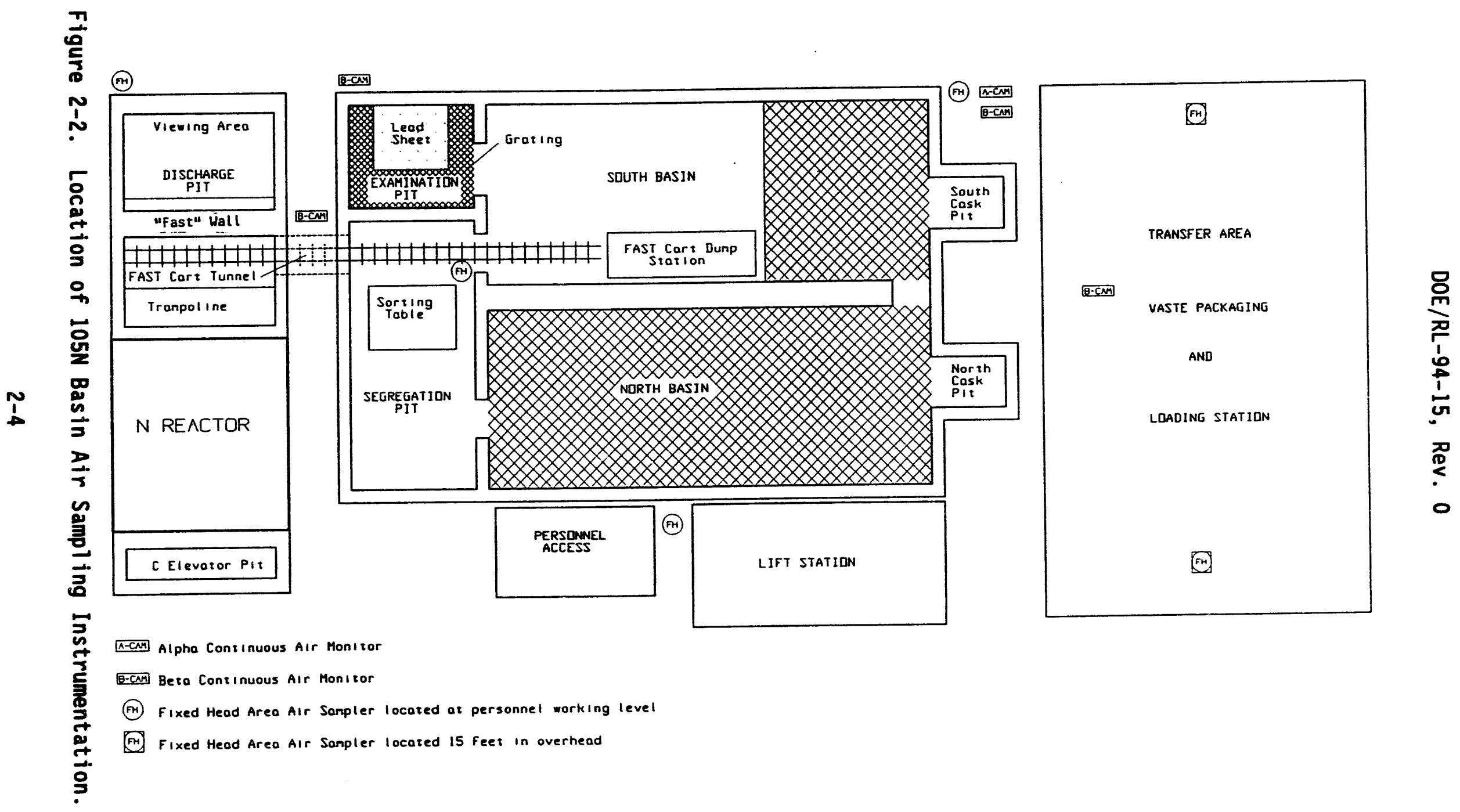




\section{Task 1 - North Cask Pit}

105N Basin stabilization activities will begin in the North Cask Pit. In conjunction with the hardware removal from the North Cask Pit, hydroscrubbing of the exposed basin surface just above the water line (commonly referred to as the "bathtub ring") will be initiated in the Viewing Area of the Discharge Pit area. Hydroscrubbing will be accomplished by the use of either a hand-held wand, or a fixed apparatus attached to one of the overhead cranes.

Removal activities will consist of relocating the debris and hardware to the North Basin. This will be accomplished by personnel standing on the platform above the pit using remote handling tools, such as the existing tongs and hooks used during routine operations. After all items have been removed from the pit, sludge will be transferred to the North Basin using the ROSEE system so that inspection for SNM can be performed. The ROSEE system will be operated by personnel above the basin using remote controls and an overhead cranes. Inspection for SNM will be accomplished using remotely operated video equipment and radiation detection instrumentation operated from a position above the pit.

The opening from the North Cask Pit to the North Basin will be closed and sealed by the installation of a pre-fabricated coffer dam to contain sediment inside the pit. The North Cask Pit will be used thereafter as a repository for all sediments moved from other areas of the basin. Once the North Cask Pit has been thoroughly cleaned, a cover will be placec over the pit. The cover is intended to provide a platform for the ROSEE system cyclone separators that will discharge into the North Cask Pit, as well as to provide a radiation shielding barrier between the sediment accumulation in the North Cask Pit and the work area around the pit.

When sediment removal activities begin, the water level in the covered North Cask Pit will be lowered approximately 8 feet by pumping water from the pit to the North Basin. Lowering the water level in the pit will provide room for the water discharged from the cyclone separators and for the accumulation of sediment. The water level in the North Cask Pit will be lowered periodically to accommodate the increase in volume created during sediment relocation activities.

\section{Task 2 - South Cask Pit}

Concurrently with installation of the North Cask Pit coffer dam, stabilization activities will also occur in the South Cask Pit. The walls of the pit will be hydroscrubbed to reduce the dose rate contribution from the "bath tub" ring for personnel working around the pit. All debris and hardware found in the pit will be relocated to the South Basin for removal with South Basin activities. Once the coffer dam is installed in the North Cask Pit, sludge and sediment will be transferred to the North Cask Pit using the ROSEE system. The South Cask Pit will then be inspected to certify that no SNM is present. The South Cask Pit will henceforth be used exclusively for loading high-dose-rate items into submerged shipping casks. 


\section{Task 3 - North Basin}

The walls of the North Basin will be hydroscrubbed to reduce the dose rate contribution from the "bath tub" ring for personnel working around the perimeter of the basin. Before removing hardware and debris, the canister cleaning and crushing equipment will be installed in the North Basin. On completing installation of the canister cleaning equipment, all loose hardware and debris located on top of the cubicle lids will be removed from the basin to gain access to the cubicle lids. Fuel baskets will either be placed in the burial or shipping containers intact or cut into smal1 pieces underwater for purposes of volume reduction. All materials will be sorted under water by radiation dose rate and only items showing acceptable radiation levels will be raised out of the basin water.

Canisters will be removed from the cubicles and cleaned as described in Section 2.1.1 to reduce the levels of radioactive contamination. The canisters then may be crushed to minimize burial volume, or left intact for shipment to an authorized DOE facility for smelting and volume reduction. The canisters will be raised out of the water, rinsed, and allowed to drain over the bas in before loading into designated burial/shipping containers.

Sediment will be removed from the cubicles using the ROSEE system and relocated to the North Cask Pit. After the sediment activities are complete, the North Basin will be inspected to certify that no SNM is present.

\section{Task 4 - Segregation Pit}

Prior to the start of cleaning activities in the Segregation Pit, the wall surfaces in the pit along the water 1 ine will be hydroscrubbed to reduce the dose rate contribution in this area. After hydroscrubbing, equipment and debris will be removed. Major pieces of equipment located in the Segregation Pit include the fuel basket dumper, sections of process tubes, the sorting table, and the fuel canister loading equipment. These large items will be disassembled or cut into smaller pieces for volume reduction. All items, debris, equipment, and hardware (excluding high-dose-rate material) will be cleaned using high-pressure water, raised out of the water, rinsed, drained, and placed in designated burial or shipping containers. The "Fast" Cart track, which runs through the Segregation Pit, will be cleaned in place and left to be stabilized with the rest of the basin.

After all loose items, equipment, and hardware are removed from the Segregation Pit, sediment will be relocated using the ROSEE system, then the Segregation Pit will be inspected to certify that no SNM is present.

\section{Task 5 - South Basin}

The walls of the South Basin will be hydroscrubbed to reduce the dose rate contribution from the "bath tub" ring for personnel working around the perimeter of the basin. Upon completion of hydroscrubbing, the canister cleaning and crushing equipment will be relocated to the South Basin. In addition, the basin encapsulation equipment, located in the southwest corner of the basin, will be disassembled to the extent possible using existing basin tools. Components removed from the encapsulation equipment will be disposed of as radioactive waste, however the remainder of the equipment will be left 
in $\mathrm{place}$ and stabilized with the rest of the basin. Canisters will be removed from the cubicles and cleaned to reduce the levels of radioactive contamination.

Sections of process tubes found at other locations in the basin will be relocated to the South Basin where they will be cut with a mechanical tube cutter, which is currently located in the basin. If the tube cutter is not operational, the process tubes will be cut into smaller sections using a guillotine device (slow-speed hydraulic shears). The cut tube sections will be loaded underwater into shielded burial casks as radioactive waste.

Sediment relocation will be initiated in conjunction with hardware and debris removal. Canister cleaning and crushing will be conducted along with disassembly of the "Fast" Cart Dump Station. All materials will be sorted under water by dose rate and only items showing acceptable radiation levels will be raised out of the basin water. When all the canisters are removed from the basin, the canister cleaning and crushing equipment will be lifted out of the basin, rinsed, and disposed of or stored.

Sediment will be relocated to the North Cask Pit from the cubicles using the ROSEE system. The South Basin will then be inspected to certify that no SNM is present.

\section{Task 6 - Examination Pit}

Prior to the start of cleaning activities in the Examination Pit, the wall surfaces in the pit along the water line will be hydroscrubbed to reduce the dose rate contribution in this area. After hydroscrubbing, equipment and debris will be removed. The task of cleaning out the Examination Pit, located east of the South Basin, will begin with dismantling and removing the lead shielding on the grating above the fuel examination station. The lead will be packaged in DOE/U.S. Department of Transportation (DOT)-approved containers for final disposition.

After all loose items, equipment, and hardware are removed from the Examination Pit, and the sediment is relocated using the ROSEE system, the Examination Pit will be inspected to certify that no SNM is present.

\section{Task 7 - Discharge Pit}

Prior to the start of cleaning activities in the Discharge Pit, the wall surfaces in the Viewing Area of the Discharge Pit will be hydroscrubbed along the water line if not already completed during Task 1 . After hydroscrubbing, equipment and debris will be removed. All items, debris, equipment, and hardware (excluding high-dose-rate material) will be cleaned using high-pressure water, raised out of the water, rinsed, and placed in designated burial or shipping containers. High-dose-rate items will be moved under water and placed in the burial cask in the South Cask Pit. The "Fast" Cart track will be cleaned in place and left to be stabilized with the rest of the basin. The "Fast" Carts, located in the tunnel running between the Discharge Pit and the Segregation Pit, will be removed, cleaned with high-pressure water, and cut up for waste volume reduction prior to being placed in burial containers or loaded into shipping containers for smelting. 
The trampoline, which is located in the Reactor Area, will not be removed as part of stabilization activities because of ALARA concerns. Inspection for fuel pieces under the trampoline will be performed with underwater radiation detection instrumentation and underwater video equipment.

A sheet metal cover will be placed over the Viewing Area of the Discharge Pit to seal off the Reactor Area from the fuel storage Area. The "Fast" Cart tunnel will also be sealed after the water is removed to accomplish this separation.

After all loose items, equipment, and hardware are removed from the Discharge Pit, and the sediment is relocated to the North Cask Pit, the Discharge Pit will be inspected to certify that no SNM is present.

\subsubsection{Underwater Activities}

Stabilization of the basin will consist of the following underwater activities.

Cleaning the surface of hardware and debris under water using manual scrubbing, high-pressure water, or a mechanical cleaning station.

Underwater cleaning of equipment, hardware, and debris found in the basin will involve personnel standing on the working platforms above the basin using handheld, remotely operated tools and controls for the overhead cranes. These tools include fuel tongs and hooks. Personnel will grasp small items with the tongs, or attach the item to a hook, so that it can be positioned near the high-pressure water nozzle. Large items will be repositioned with the remotely operated overhead cranes. Personnel will then direct the high-pressure water on the item to be cleaned. In some cases, a wire brush on the end of a pole may be used to scrub items that may be encrusted with loose scale. Fuel canisters will be cleaned at a mechanical cleaning station positioned underwater. The item will then be placed near an underwater radiation detector to determine its associated radiation reading to assess handling requirements.

The canister cleaning station is a specially designed hydraulically actuated automated cleaning device. When canisters are removed from the cubicles, they will be placed on the cleaning station. The canisters are inverted and placed over the rotating brushes. The external surface of the canisters will be washed with high-pressure water. The outside surface of the aluminum canisters will be scraped to remove loose scale at the canister cleaning station. The canisters then will be removed from the canister cleaning station and either moved to the canister crushing station, or removed from the basin for shipment to an offsite DOE facility.

The following table lists the material in the basin that is scheduled to be cleaned and the cleaning method.

The actual quantity of debris in the basin is not known, however the type of material expected to be encountered includes hoses, wire, "buggy springs" (items that were part of the fuel element assembly), and items that accidently fell into the basin, such as, gloves, plastic, and hand tools. 
105N Basin Material Inventory.

\begin{tabular}{|c|c|c|}
\hline Material & Quantity & Cleaning method \\
\hline Cubicle Lids & 536 & High-pressure water. \\
\hline $\begin{array}{l}\text { Fuel Shipping } \\
\text { Capsules }\end{array}$ & 45 & High-pressure water. \\
\hline $\begin{array}{l}\text { Fuel Storage } \\
\text { Canisters }\end{array}$ & 1500 & Mechanical cleaning station. \\
\hline $\begin{array}{l}\text { Canister Covers } \\
\text { (Caps) }\end{array}$ & 140 & High-pressure water. \\
\hline Fuel Baskets & 146 & $\begin{array}{l}\text { High-pressure water and manual } \\
\text { scrubbing. }\end{array}$ \\
\hline Fuel Spacers & 40 & High-pressure water. \\
\hline $\begin{array}{l}\text { "Fast" Cart Dumping } \\
\text { Station }\end{array}$ & 3 & $\begin{array}{l}\text { High-pressure water and manual } \\
\text { scrubbing. }\end{array}$ \\
\hline $\begin{array}{l}\text { Fuel Sorting Table } \\
\text { and Packaging Sta. }\end{array}$ & 1 & $\begin{array}{l}\text { High-pressure water and manual } \\
\text { scrubbing. }\end{array}$ \\
\hline Fuel Dump Baskets & 1 & $\begin{array}{l}\text { High-pressure water and manual } \\
\text { scrubbing. }\end{array}$ \\
\hline Cubicles & 536 & Vacuum using ROSEE system. \\
\hline FAST Carts & 3 & High-pressure water. \\
\hline Debris & unknown & $\begin{array}{l}\text { High-pressure water and manual } \\
\text { scrubbing. }\end{array}$ \\
\hline
\end{tabular}

Using ROSEE to vacuum sediment and small debris, separate out the water and transfor the sediment and debris to the North Cask Pit.

The components of the ROSEE system include a submersible tractor equipped with lights, video camera, robotic arm, radiation detector, and vacuum head; a cubicle-cleaning vacuum head; a trash separator with radiation detector to collect the large debris from the vacuum stream; a positive displacement pump that operates at 90 gallons per minute; and two parallel cyclone separators. Figure 2-3 shows the system configuration and layout.

The cyclone separators will direct a flow, approximately 10 gallons per minute, consisting of sediment particles 10 microns and 1 arger into the North Cask Pit. The remaining flow from the cyclone separators will pass through a backwashable filter unit to remove the particles 10 microns and smaller. The backwash from the filter unit will be discharged into the North Cask Pit. 


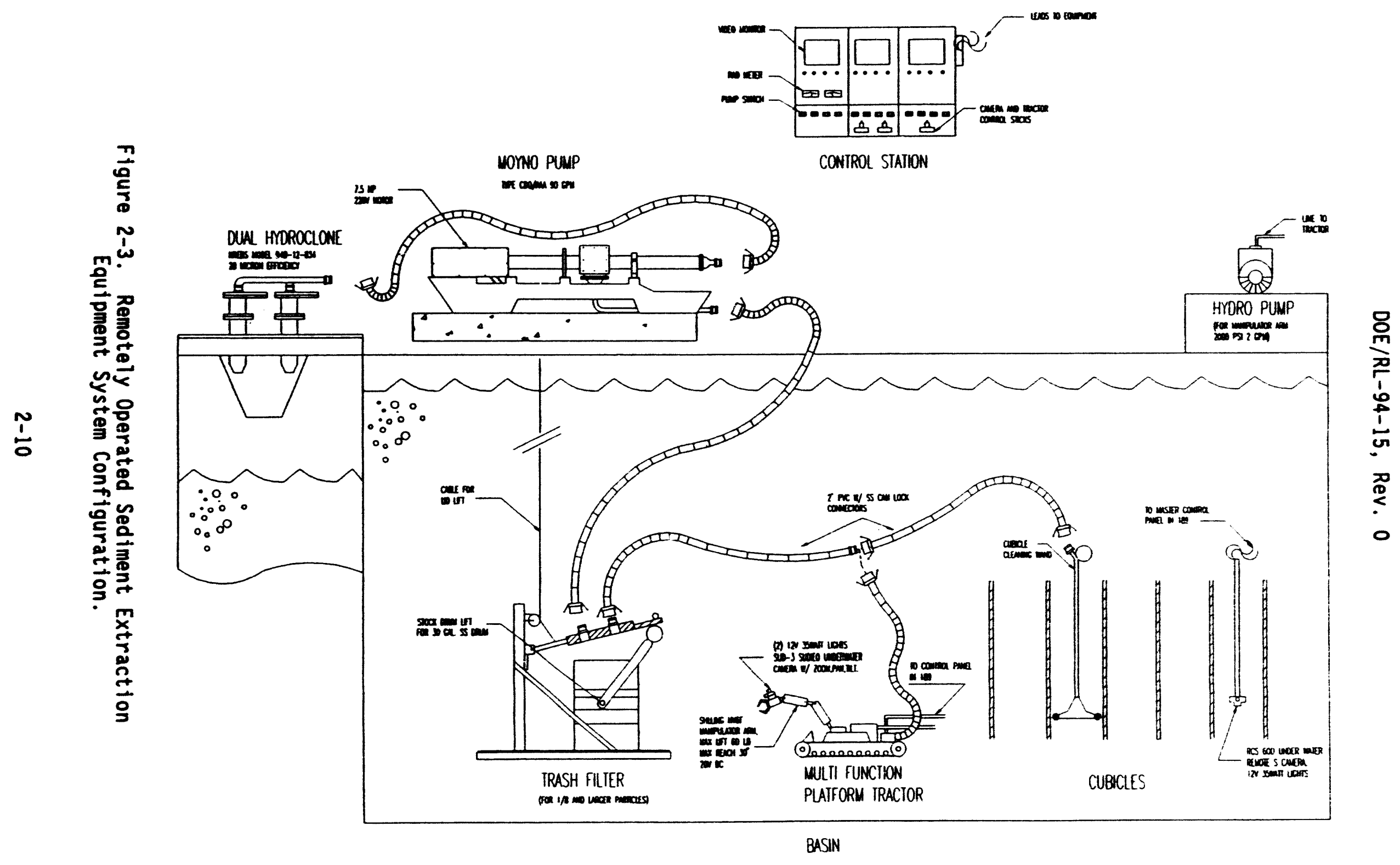


The tractor component will be positioned in the basin with one of the overhead cranes. Operation of the tractor will be performed by personnel using a remote control station. The vacuum attachment on the tractor can be operated through the vacuum head built into the bottom of the tractor, or the robotic arm can remove the vacuum hose and manipulate it in front of the tractor unit. The radiation detector on the robotic arm will be used to identify potential fuel pieces or fragments found in its path. The tractor unit will traverse the tops of the cubicles or basin floor until all visible sediment is removed.

Canister removal and cubicle cleaning will be handled in the following sequence. First, the cubicle lids will be vacuumed with the ROSEE system to remove sediment from the tops of the cubicles. Each cubicle will then be opened to gain access to the canisters. When the canisters are removed from a cubicle, the cubicle lid will be placed back in the closed position. When all the canisters have been removed, the cubicles will be cleaned out with the ROSEE system. This will be accomplished by cleaning and inspecting one row of cubicles at a time. For example, cleaning will start at row 1, cubicle 1. The 1 id $w 111$ be removed and placed in a fuel basket. The ROSEE suction head will be lowered into the cubicle, then withdrawn. Next, the video camera will be lowered into the cubicle to inspect for SNM. This sequence will be repeated until all cubicles in the row, and all cubicles in the basin, have been cleaned and inspected. Once a fuel basket is full of 1 ids, it will be moved under water to the North Basin where the 1 ids will be hydroscrubbed underwater before they are brought out of the basin and placed into designated burial/shipping containers.

\section{Crushing fuel canisters under water at a hydraulic-powered crushing station.}

The approximate number of canisters in both the North and South Basins are estimated to be 1,$500 ; 1,200$ of which are of the stainless steel type and 300 of the aluminum type. The preferred method of canister disposal is to ship them offsite for volume reduction at a DOE-approved smelting facility. If the preferred method is not selected, the canisters will be crushed in the basin and packaged for disposal on the Hanford Site.

The canister crushing station is a specially designed hydraulic ram system that can crush both stainless steel and aluminum canisters. The crushing station will be lowered into the basin and set on top of the cubicles where the canisters are to be removed. One canister at a time will placed in the crushing device. The hydraulic ram will compress the canister to approximately 17 percent of its original volume. The crushed canister will be removed from the device and removed from the basin for disposal.

Cutting large items under water, such as process tubes, sorting table, fuel baskets, into smaller sections for packaging.

All cutting activities will be performed under water. The following table identifies the material to be cut and the method of cutting. 
Volume Reduction Methods.

\begin{tabular}{|l|l|l|}
\hline \multicolumn{1}{|c|}{ Item } & \multicolumn{1}{|c|}{ Method } & \multicolumn{1}{c|}{ Description } \\
\hline Process Tubes & $\begin{array}{l}\text { Tube Cutter/ } \\
\text { Gulllotine }\end{array}$ & $\begin{array}{l}\text { Tube cutter currently in basin. } \\
\text { It is air operated with the } \\
\text { exhaust plumbed to atmosphere. } \\
\text { The Guillotine is a hydraulic } \\
\text { shear and will be used under } \\
\text { water. }\end{array}$ \\
\hline Fuel Baskets & Plasma Arc & $\begin{array}{l}\text { Will be cut into smaller sections } \\
\text { under water. }\end{array}$ \\
\hline $\begin{array}{l}\text { Sorting Table and } \\
\text { "Fast" Carts }\end{array}$ & Plasma Arc & $\begin{array}{l}\text { Will be cut into smaller sections } \\
\text { underwater. }\end{array}$ \\
\hline
\end{tabular}

Process tubes located in the basin are considered high-dose-rate items, and therefore, will not be raised out of the basin water. Instead, they will be placed into the underwater cask and buried as radioactive waste on the Hanford site. Because the process tubes are of various lengths, they will have to be cut to fit in the burial cask. The process tubes will be cut with the existing tube cutter currently located in the basin. The tube cutter is an air-actuated device that operates in the same manner as standard pipe cutters. If the tube cutter in the basin is found to be inoperable, a "gutllotine" device will be placed in the basin to cut the process tubes. This device has a hydraulic-actuated blade that shears off sections of tubing.

Moving high-dose-rate items underwater and packaging in designated under water burial/shipping containers.

All high-dose-rate material and items will be handled, moved, and packaged under water. Current survey data have identified most of the high dose rate items. However, many items or sources of high radiation levels could not be identified because of the conjunction of material in some of the pits. Movement of small items will generally be performed by personnel using remote handling tools and keeping the object under water. Larger items will be attached to a crane hook and moved under water. Figure 2-4 depicts the flow path for movement of high-dose-rate items under water.

\subsubsection{Above Mater Activities}

Stabilization of the basin will consist of the following above water activities. 
DOE/RL-94-15, Rev. 0

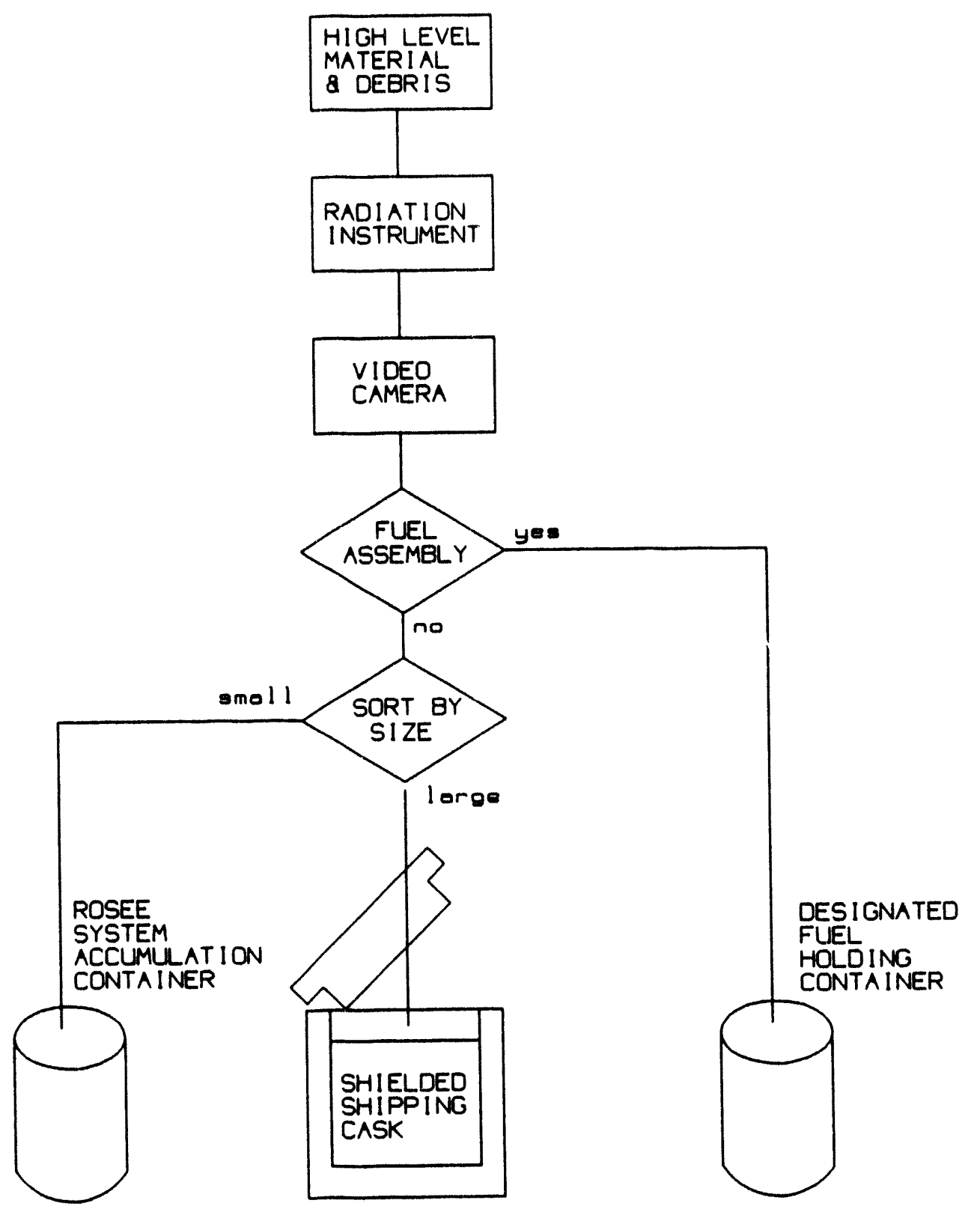

Figure 2-4. High Level Radioactive Material Flow Diagram. 
Lifting hardware and large debris from the basin water and packaging in designated burial/shipping containers.

Low-dose-rate items will first be hydroscrubbed under water to remove loosely attached surface contamination, then raised out of the water and rinsed with filtered basin water. Rinsing activities will not add additional water to the basin. Rinse water for the decontamination activities will use the discharge from the basin filtration system installed for maintaining $1:$ :er clarity.

Smaller items, such as, tools, hoses, cabies, small metal components, and debris, will be placed in an underwater accumulation container. When the accumulation container is full, the contents will be used to fill the voids in the underwater shipping cask located in the South Cask Pit. These shipping casks were specially designed to transport irradiated fuel to various locations within the Hanford Site.

High-dose-rate items will not be raised out of the water. These items will be packaged under water in approved shipping/burial casks for disposal. Smaller objects with high-dose-rates will also be used to fill voids in the underwater casks. When the cask is full, it will be raised out of the basin and washed off with filtered basin water as it is withdrawn. The cask will be drained using built-in drain valves and set down at a designated location just west of the cask pit. After the cask has dried, it will be painted to fix any residual contamination on its surface. The cask will then be relocated to a designated staging area in the basin and covered with plastic until it is loaded onto a flat-bed truck for transportation to an authorized disposal facility.

It is important to note that all material and debris not easily recognizable will be inspected with underwater video equipment to determine its identity. Therefore, all fuel assemblies, if discovered, and fuel chips or fragments will be placed in a designated canister located in the basin. Upon final inspection of the basin, all canisters holding fuel will be loaded into an underwater shipping cask, which will be transported to the $100-K$ fuel storage basin for final disposition.

Mash basin walls with high-pressure water. This activity will be conducted out of and above the water.

The purpose of this activity is to reduce the dose rates created by radioactive material plating out, or leaching into the basin wall surface along the water line, often referred to as the "bathtub ring" effect. This activity will be performed by personnel using a high-pressure lance.

Personnel will stand on the working platform above the edge of the basin and direct the blast of the water lance along the basin wall surface. The nozzle of the lance will be held approximately 6 inches from the wall surface and directed down toward the bas in water at an angle of approximately 33 degrees. The cleaning rate is expected to be approximately 3 feet per minute. 


\subsection{DESCRIPTION OF THE 105N BASIN INVENTORY}

This section provides detailed information regarding the radionuclide inventory affected by the proposed basin stabilization project.

\subsubsection{Radionuclide Sources}

$105 \mathrm{~N}$ Basin was designed as a place to package and temporarily store spent fuel elements and irradiated fuel spacers discharged from the $N$ Reactor. Fuel handling and storage operations were conducted in seven interconnected basins with a common pool of water, one other remote basin ("C" Pit), and a water ilft station. During $N$ Reactor operation, underwater transfer carts moved the spent fuel elements from their discharge point at the rear face of the reactor to the storage basin, where they were sorted by enrichment and placed in storage canisters. The filled canisters were moved by bridge cranes to storage cubicles, formed by a lattice of borated concrete walls. The basin began operation in 1963 and ceased storing spent fuel in 1989, when all fuel was transferred to the $100-K$ fuel storage basins.

A significant amount of radioactive material was deposited in the basin as a result of the fuel handling and storage operations. Sources of radionuclides included the following:

- Irradiated uranium fuel elements with damaged cladding that introduced spent fuel particles (including transuranic isotopes and fission products) into the basin water and sediment

- Irradiated lithium targets with damaged cladding that introduced tritium into the basin water

- Corrosion of irradiated reactor hardware (e.g., spacers, buggy springs)

- Hardware and debris with surficial deposits of contamination.

Fuel elements and tritium targets are no longer stored in the basin. However, small fragments from damaged fuel elements are potentially present. In addition, an observed increase in tritium activity in the basin water indicates that a lithium target or fragments of targets remain in the basin. The current inventory of radionuclides in the basin is presented in Section 2.2.2.

\subsubsection{Radionuclide Inventory of 105N Basin}

Radionuclides are assumed to be present in the basin in four physical forms as follows:

- Solute and suspended solids in basin water

- Basin sediment and wall deposits

- Surface deposits on hardware

- Fragments of irradiated fuel elements and lithium targets. 
The radionuclide inventory associated with each physical form, decay-corrected to February 1994, is presented in Table 2-1. The basis for the inventory is discussed below.

Water. The basin complex contains approximately 4.1 million liters ( 1.08 million gallons) of water (Appendix A-1). A grab sample of the water is collected monthly and analyzed. Suspended solids measured in the water samples typically constitute about 5 parts per million by weight, and the activity in these solids is included in the reported analyses. The water activity presented in Table 2-1 is based on the mean activity of samples collected from August 1992 to August 1993 at the upper 95 percent confidence limit ${ }^{\uparrow}$.

Sediment. A layer of sediment, ranging from 0 to 3 inches thick (Subrahmanyam 1988), covers the bottom of the basin. It is composed of fine silt and dust, insect matter, algae, corrosion products, and small debris. Given the thickness of the sediment layer, the total volume of settled solids in the basin has been estimated at $1.16 \times 10^{4}$ liters ( 410 cubic feet) (Subrahmanyam 1988). Based on laboratory measurements of the density of the settled solids versus centrifuged solids, the total volume of centrifuged solids in the basin has been estimated at $1.74 \times 10^{3}$ liters (61 cubic feet) and the mass of centrifuged solids has been estimated at 2,000 kilograms (Subrahmanyam 1988). For conservatism in calculating the source term, the volume of solids has been assumed to be 70 cubic feet.

In 1987, nineteen samples of the sediment were collected and analyzed from different locations throughout the basin (Subrahmanyam 1988). Sediment activity was reported based on centrifuged solids. Because reactor operations ceased in January of 1987, and all fuel was removed from the bas in by 1989 , the 1987 data (with appropriate decay corrections for the intervening years) are expected to be representative of the current source term in the sediment. The sediment activity presented in Table 2-1 is the mean activity of the centrifuged sediment samples at the upper 95 percent confidence limit ${ }^{1}$.

Hardware. A variety of hardware and debris is present in the basin. The types of hardware and estimated volumes, masses, and surface areas are presented in Table 2-2.

Only a small fraction of the total hardware, primarily process tubes, fuel spacers and buggy springs, was irradiated in the reactor and would be expected to contain activation products. The activation products are an integral part of the metal of the hardware and are not available to the air.

The majority of contamination associated with the hardware is present in the corrosion and other deposits that have accumulated on the surface of the hardware. In 1990, 12 aluminum fuel canisters were removed from the basin.

\footnotetext{
${ }^{1}$ The confidence interval is a range on either side of a sample mean. A statistical evaluation was done based on the mean, the standard deviation of the data, and the number of samples. At the upper 95 percent confidence $l$ imit in a one-sided test, there is a 95 percent probability that the true mean is equal to or less than the limit.
} 


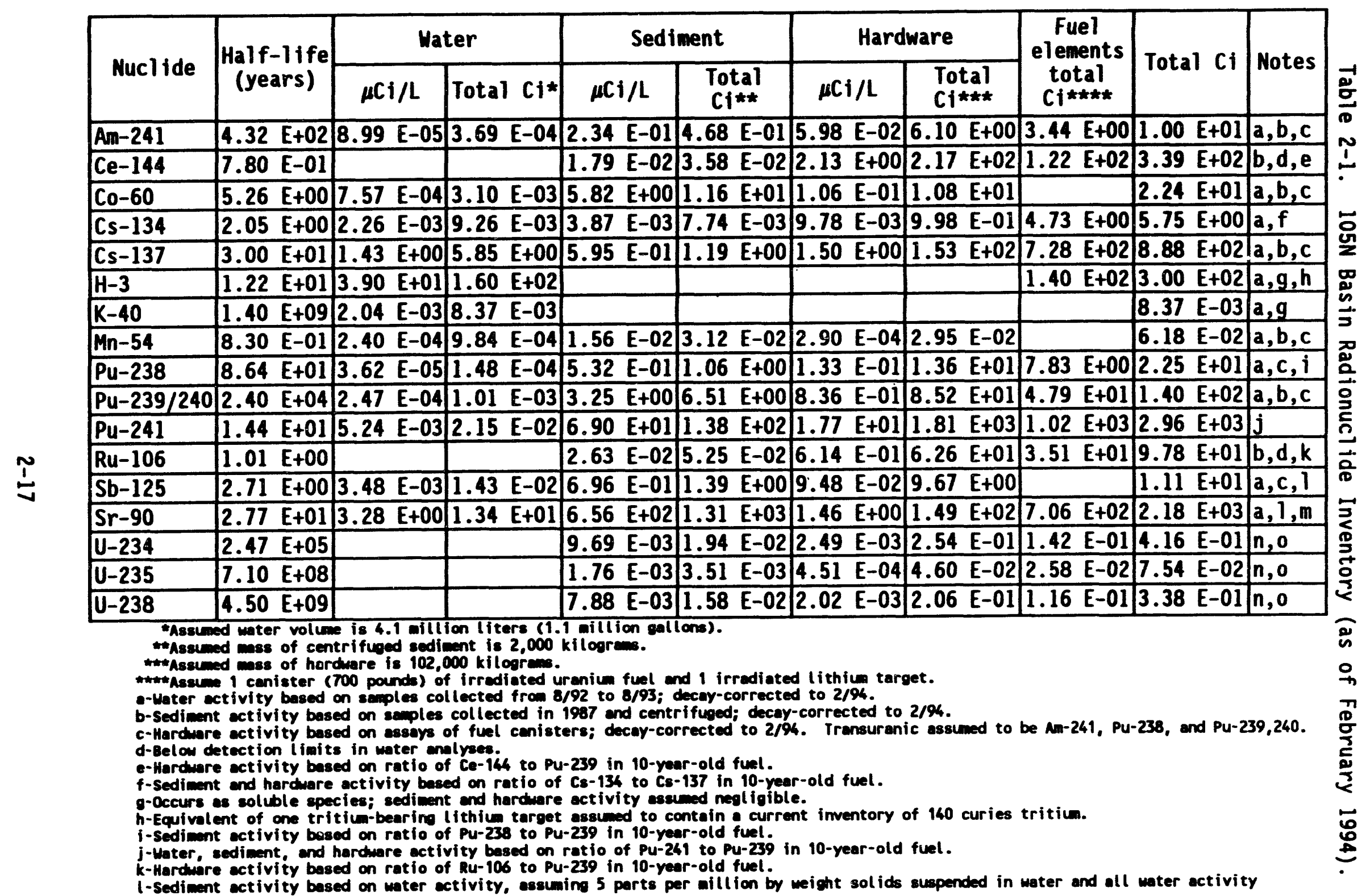
at tributable to suspended sol ids.

m-Marduare ectivity based on ratio of Sr-90 to Cs-137 in 10-year-old fuel.

n-Mot analyzed in water samples; assued negliont and hardware activity besed on ratios to Pu-239 in 10-year-old fuel. 


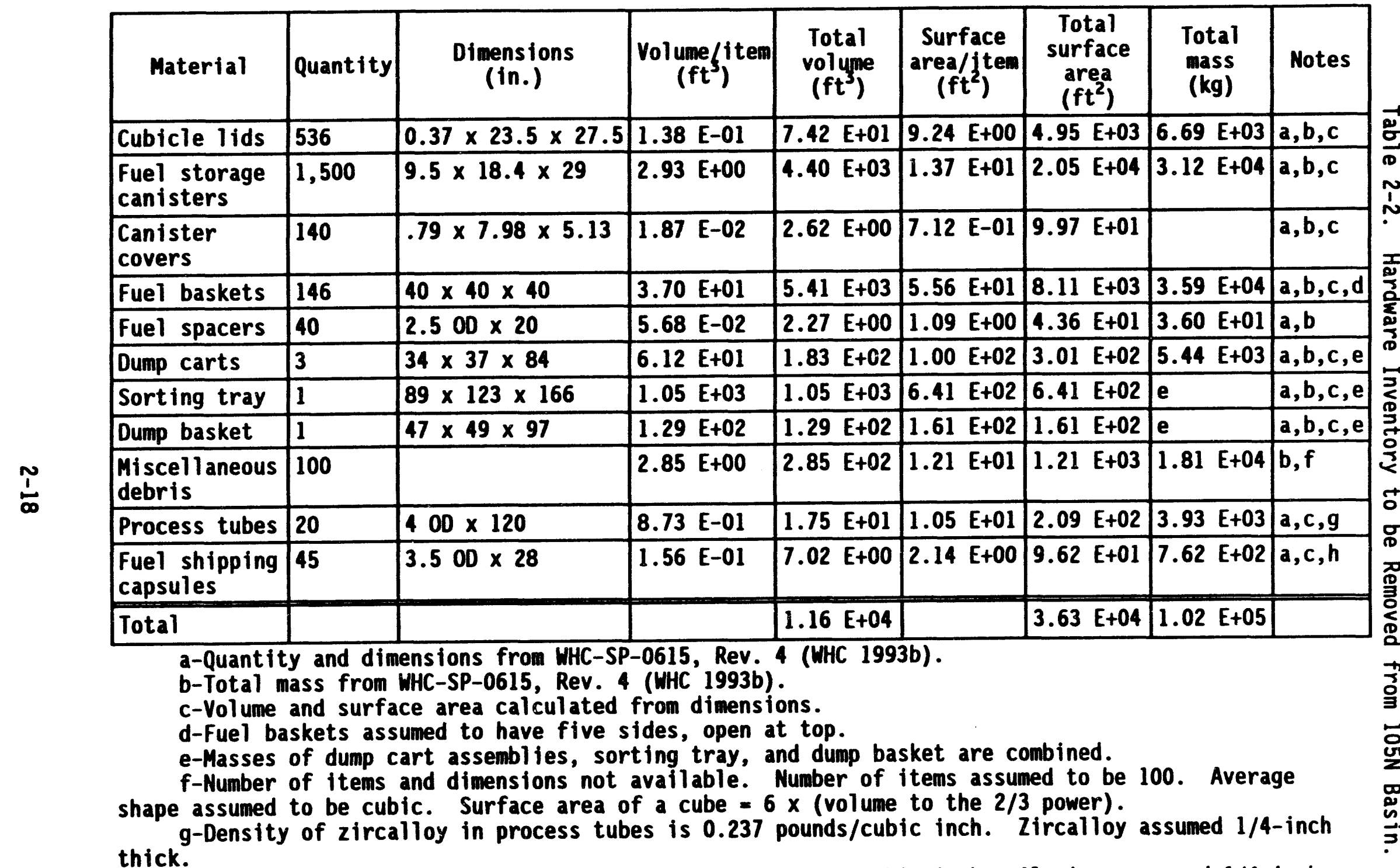
thick.

h-Density of aluminum in shipping capsules is 0.1 pound/cubic inch. Aluminum assumed 1/4-inch OD = outside diameter. 
All 12 were assayed for transuranic isotope activity and two were assayed for gamma radionuclides as part of an evaluation of cleaning techniques. Activity was reported as curies per unit mass of the canisters (Appendix A-3).

The level of contamination associated with the aluminum canisters is expected to be higher than for the stainless steel canisters or other hardware in the basin. The aluminum canisters comprise approximately 300 of the 1,500 canisters in the basin (WHC 1993b). The other 1,200 canisters, which are constructed of stainless steel, and most of the other hardware in the basin, is constructed of either stainless or carbon steel. Aluminum develops a relatively thick, porous corrosion surface that adheres tightly and traps contaminants. The aluminum itself is a relatively porous material. In contrast, stainless steel does not develop a corrosion surface, and film deposits wash off readily. In addition, the aluminum canisters are an older design that includes drainage holes and a mesh screen in the bottom on which material, including fuel fragments and sediment deposits, has collected over the years. The stainless steel canisters have smooth bottoms without holes or screens, so material has not accumulated.

Because other hardware in the bas in has not been assayed, the activity-per-unit-mass data for the aluminum canisters have been assumed to apply to the rest of the hardware as we11. Table 2-1 presents the mean activity of the aluminum canisters at the upper 95 percent confidence interval ${ }^{2}$. The total hardware activity presented is based on the total mass of hardware in the basin. However, for the reasons stated previously, it should be understood that use of the aluminum canister assay data is a conservative case.

Irradiated Uranium Fuel Fragments. Based on visual inspection and past SNM records, the basin has been declared free of any known quantities of irradiated uranium fuel. However, for planning purposes, it has been assumed that some fuel element fragments will be found during basin stabilization activities. The volume of fuel found is assumed to fit into one fuel canister. The assumption is a conservative estimate. It is anticipated that if any fuel fragments are found, the quantity will be less than one canister. However, one canister will be needed to handle any fuel fragments. Therefore, for ease in calculating potential emissions, one canister volume was used. A canister is designed to hold 14 fuel element assemblies, with one fuel element assembly weighing approximately 50 pounds, giving a total approximate fuel weight of 700 pounds.

2The confidence interval is a range on either side of a semple men. A statistical evaluation was done based on the men, the standard deviation of the data, and the muber of semples. At the uppor S5 percent confidence limit in a one-sided test, there is: 95 percent probability that the true meen is equal to or less then the limit. 
The fuel fragments result from fuel that was discharged from $N$ Reactor between 7 and 31 years ago. To calculate the source term associated with the fragments, the following assumptions were made:

- The majority of the $N$ Reactor fuel was 0.95 weight percent enriched with ${ }^{255} \mathrm{U}$ isotope. A small amount of natural uranium fuel was also irradiated. Because more highly enriched fuel results in higher radionuclide levels, the fragments are assumed to result from enriched fuel.

- Fuel can be irradiated to either weapons-grade assay levels ( ${ }^{240} \mathrm{Pu}$ levels of 6 percent) or fuels-grade assay levels ( $(240 \mathrm{Pu}$ levels of 12 percent). Fuels-grade levels are reached through longer irradiation times and result in higher radionuclide levels. Because the source of the fragments is unknown, it is assumed that they are fuels-grade.

- A 10-year average decay time was assumed for the fuel fragment inventory.

The radionuclide inventory associated with the fuel fragments is provided in Table 2-2.

Irradiated Lithiun Targets. Visual inspection has not revealed the presence of tritium-bearing lithium targets. However, basin water samples show a continual increase in tritium activity. The increase has been attributed to the presence of a lithium target or target fragments in quantities approximating one target. Target failures during past operations resulted in the release of approximately 140 curies of tritiun per target. For inventory purposes, it is assumed that a target or fragments of targets contain 140 curies of tritium. 
DOE/RL-94-15, Rev. 0

\subsection{EMISSIONS CONTROL SYSTEM}

\subsection{EFFLUENT SYSTEM LAYOUT}

This section describes the ventilation system for the basin and the removal efficiencies for control devices in the system.

The $N$ Reactor is separated into five confinement zones for radiation control purposes. Confinement Zone I is the innermost zone surrounding the reactor core and its directly associated systems and areas. Because of high radiation levels around the reactor, Zone I is vented through a highefficiency particulate air (HEPA) filtration system located in the $117 \mathrm{~N}$ Filter Building prior to discharge through the $116 \mathrm{~N}$ stack. Zone I is maintained at a negative pressure relative to other zones and the external atmosphere.

Prior to 1993, part of the basin air space (considered part of Zone III) was exhausted directly to the atmosphere via roof exhausters. In October 1993, doorways between Zone I and the basin were opened to allow air to flow from the basin to Zone I. Tests were conducted that demonstrated that the new configuration maintained a negative pressure differential of -0.02 inch to -0.1 inch water gauge between the basin, adjacent air spaces, and the atmosphere (Myott 1993). The new configuration was approved for permanent use, and the $N$ Reactor Zone I ventilation system with its HEPA filtration system now serves as the ventilation system for the basin.

The basin/transfer area airflow configuration is shown in Figure 3-1. Figure 3-2 shows the airflow configuration through the 117N HEPA Filter Building.

The bank of HEPA filters in the 117N Filter Building is the control device used for removal of radioactive particles from the basin ventilation system. In accordance with Hanford Site procedures, an installed HEPA or HEPA-equivalent filter shall have a leakage rate efficiency of 99.95 percent for removal of airborne particulate (WHC 1993a). The basis is The Nuclear Air Cleaning Handbook, Section 8.2, which states that by definition a HEPA system must exhibit an installed decontamination factor of 2,000; an efficiency of 99.95 percent for aerosols having a nominal median diameter less than 1 micrometer (WHC 1993a).

The testing and inspection of the treatment system will be done in accordance with protocols established for the Hanford site. At a minimum, the efficiency of the HEPA filters will be tested annually and must meet the following requirements.

- All filters shall remove at least 99.95 percent of the Hanford Site-approved aerosol particles with particle size ranges and median diameter in accordance with WHC-CM-7-5 (WHC 1993a).

- The HEPA filter cartridges shall be replaced when continuous exposure rates exceed $1 \mathrm{R} /$ hour at 15.3 centimeters ( 6 inches), or when the pressure drop across the filter exceeds 5 inches water gauge. 
DOE/RL-94-15, Rev. 0

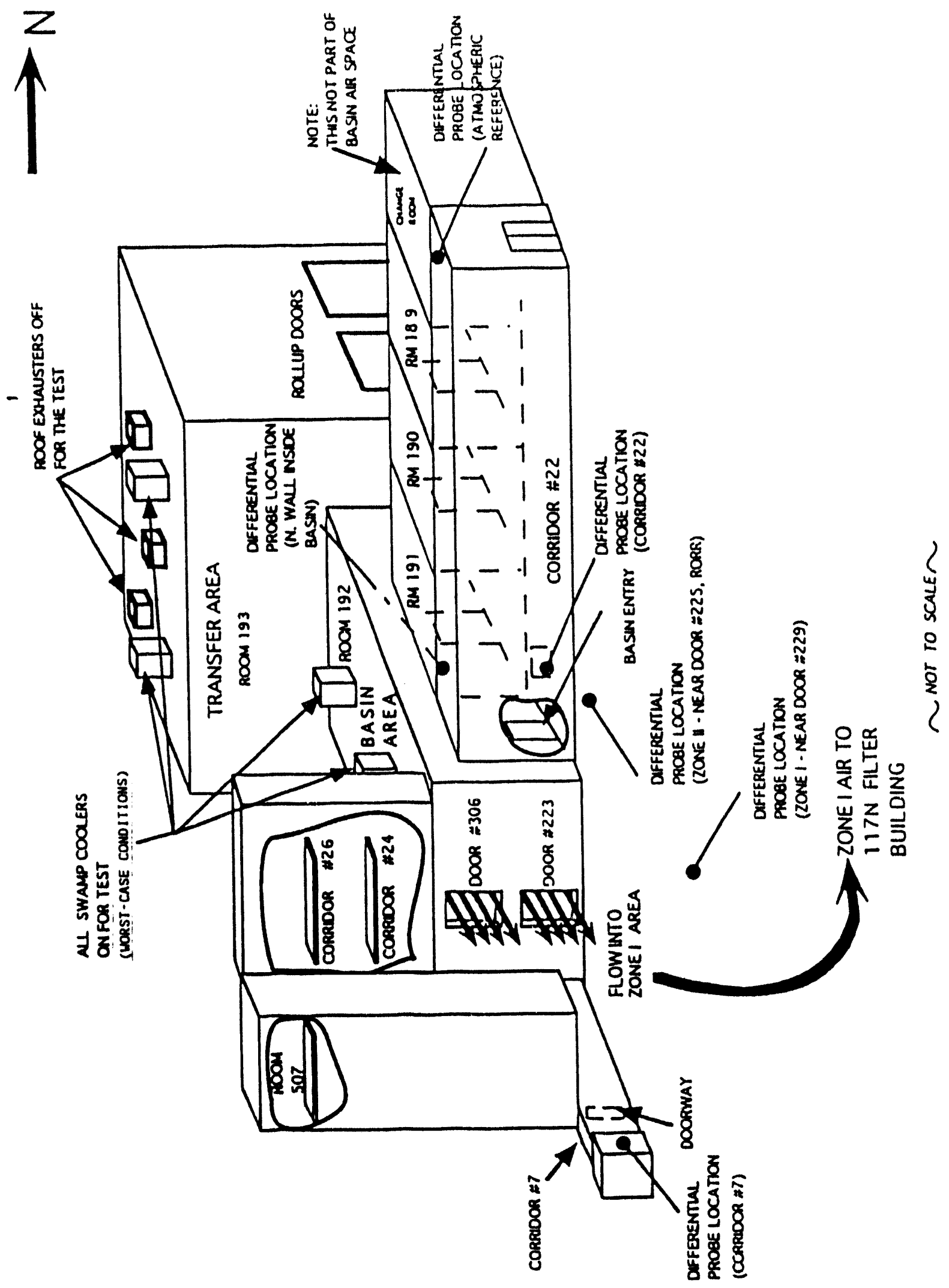

Figure 3-1. Simplified Sketch 105N Basin/Transfer Area Air Space. 


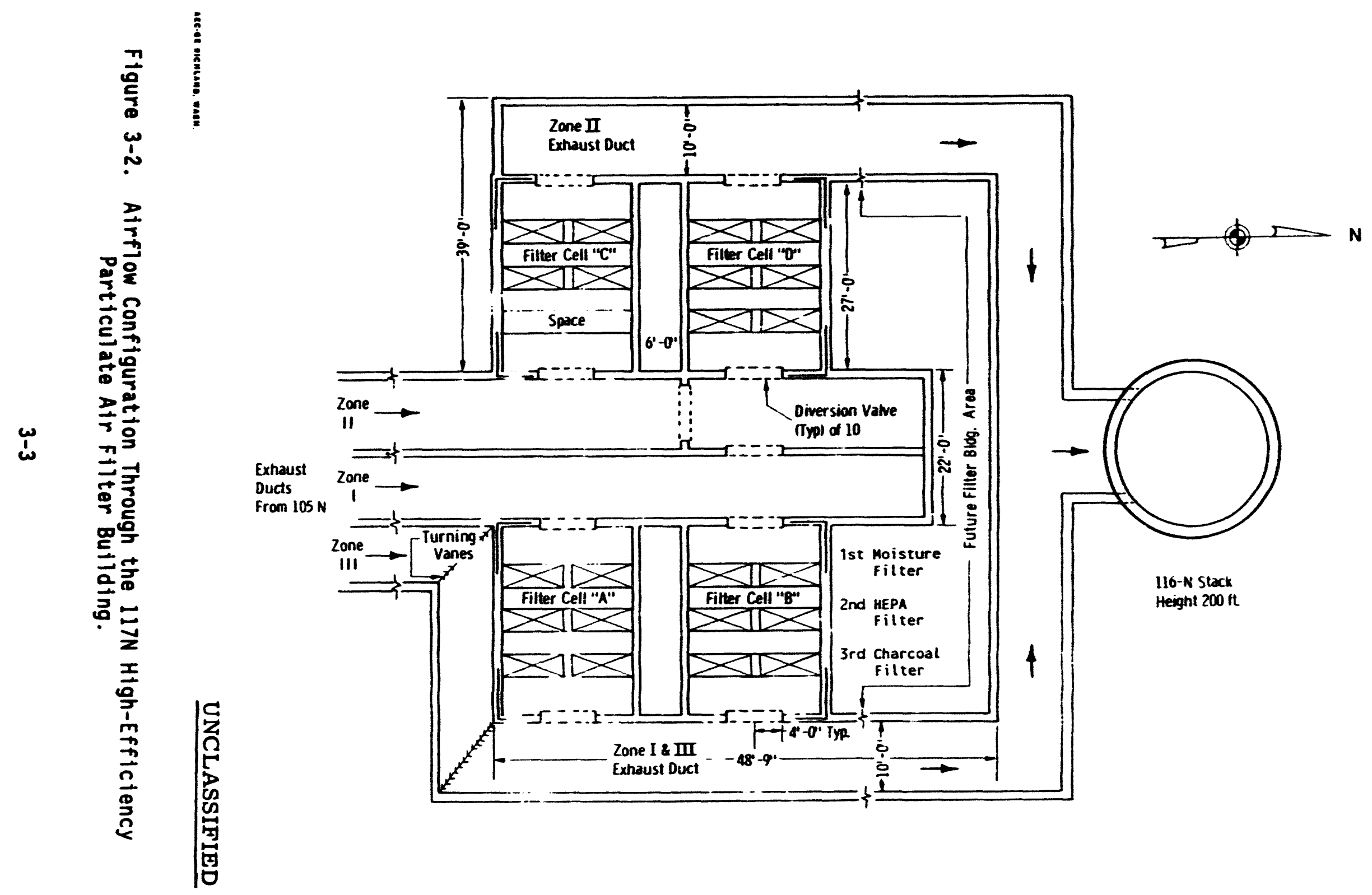


DOE/RL-94-15, Rev. 0

- Remotely installed HEPA filters shall be replaced when the pressure drop across the filter exceeds 5 inches water gauge, or exposure rates exceed Iimits provided by Radiation Protection.

\subsection{EAISSIONS RELEASE RATES}

This section provides detalled information regarding the source and quantity of airborne radionuclide emissions resulting from the proposed basin stabilization activities. Represented are the estimates of the total radionuclide inventory in the basin, the mechanisms whereby radionuclides are transported to the basin air space, the source term in the air space, and the atr emissions. The expected annual average release rates of the radionuclides emitted by the basin were calculated using good engineering judgement (GEJ) which provide a more realistic description of the expected potential omissions than 40 Code of Federal Regulations (CFR) 61, Appendix D Methodology.

\subsubsection{Cheotcal and Phystcal Forms of Roleases}

Airborne releases from the basin stabilization project will be primarily particulate forms. The dominant chemical spectes are likely to be oxides and hydroxides of the radionuclides. Salts (e.g., chlorides, nitrates) might also occur. The only significant volatilized radionuclide will be tritium.

\subsubsection{Cood Engineering Judgement Entssions Estimate}

This section provides the engineering evaluations and assumptions used in determining the GEJ emissions estimate.

Stabilization of the basin will consist of several activities. Activities performed under water include the following:

- Cleaning the surface of hardware and debris using manual scrubbing, high-pressure water, or a mechanical cleaning station

- Crushing fuel storage cantsters at a hydraulic-powered crushing station

- Placing smaller items inside larger items to reduce waste volumes

- Cutting large ttens (e.g., process tubes, a sorting table, fuel baskets) into smaller sections for packaging. Potential cutting mothods include plasma torch, hydraulic shears or nibblers, and tube cutters

- Using ROSEE to vacuum sediment and small debris from the basin, separate out water, and transfer the sediment and debris to the North Cask Pit. 


$$
\text { DOE/RL-94-15, ReV. } 0
$$

Abovewater activities include the following:

- Lifting hardware and large debris from the basin and packaging into approprtate shipping containers

- Washing basin walls with high-pressure water.

Based on these activities, the following mechanisms for transporting radionuclides to the basin air space are evaluated as follows:

- Evaporation

- Debris washing, crushing, packaging, and removal

- Cutting

- Hydrowashing basin walls.

Evaporation. For planning purposes, it has been assumed that approximately 302,800 11ters ( 80,000 gallons) of water $w 111$ evaporate annually from the basin during the stablitization project (Appendix $A-1$ ). The current rate of evaporation is approximately 227,100 ilters/year $(60,000$ gallons/year). The assumed quantity of 302,800 liters addresses the potential for enhanced evaporation due to increased surface area as stabilization is conducted.

With the exception of tritfum, the amount of radloactivity transported to the air via this mechanism is assumed to be negitgible. Both the vapor pressure and the mole fraction for each of the radionuclides in the water are very small, so the partial pressure (the product of vapor pressure and mole fraction) would be extremely small.

Tritlum occurs in the water as tritlated water, and is assumed for this evaluation to have the same vapor pressure as nontritiated water. Assuming a net evaporation rate of 302,800 itters/year and a tritium activity of 39 microcurles/liter, the source term from evaporation will be 11.8 curies/year of tritium.

Dobris scrubbing, Packaging, and Removal. Radiological control procedures will be in place to minimize dispersion of contaminants during debris handing and removal activities. However, it is assumed that underwater activities will resuspend at least some of the settled sediment into the overlying water, increasing the activity of the water. Splashing might occur during these activities that could generate airborne droplets or contaninate surfaces outside of the storage pools. As the water film adhering to the hardware and debris is removed, it could al so generate airborne droplets and/or contaminate surfaces outside of the pools.

While large water droplets are expected to fall back into the pools, small water droplets could evaporate quickly in the air (because of the iarger surface area-to-volume ratio) resulting in both soluble and insoluble radionuclides becoming airborne. Very small droplets (less than 10 micrometers) could be carried away by the air flow. Water that splashes outside the storage pools could dry on exposed surfaces of the basin; radionuclides from the water residue could then be resuspended as particulate. 


$$
\text { DOE/RL-94-15, ReV. } 0
$$

To determine the potential emissions, the following was assumed:

- The quantfty of water droplets formed above the storage pools and the amount of splashing to outside surfaces is related to the amount of hardware being handled and removed from the pool

- A 1-millimeter film of water adheres to each piece of hardware removed from the basin

- 10 percent of the volume of this film is dispersed to the basin atr space through evaporation, carryover of small droplets, or splashing and resuspension outside the storage pools. The 10 percent value was determined using GEJ and is conservative.

The total surface area of hardware was determined to be approximately 3,300 square meters $(36,300$ square feet) (Table $2-2)$. Using the above assumptions, the volume of water dispersed to the air space is:

$$
3300 m^{2} \times 1 \mathrm{~mm} \times \frac{1 \mathrm{~m}}{1000 \mathrm{~mm}} \times \frac{10001}{1 m^{3}} \times 10 \%=33011 \text { ters }
$$

The net result is that 330 liters of water with suspended solids is added to the air space. The activity of the water assumes the following:

- 100 percent of the sediment in the vicinity of a plece of hardware being handled is resuspended into the columen of water overlying sedimant. (The resulting water-solids mixture contains about 500 parts per willion by weight solids.)

- The activity per unit mass in the sediment is relatively uniform throughout the basin. This was supported by statistical evaluations of the 19 sediment samples collected from different locations of the basin in 1987 (Subrahmanyam 1988).

- The mass of sediment is uniformly distributed throughout the basin.

- All of the activity assoclated with the hardware is assumed to be removed during cleaning and also disperses into the water throughout all of the basin.

The activity of the water, including the suspended solids, is provided in Table 3-1. The emissions total from debris handling and removal is the activity multiplied by 330 liters of water.

Cutting Activities. Hardware that might have to be cut prior to packaging consists of process tubes, a sorting table, and fuel baskets, all of which are constructed of steel. Cutting w111 be performed under water at depths of approximately 20 feet or greater. Potential cutting methods include plasma torch, hydraulic shears or nibblers, and tube cutters. 
Table 3-1. Emisstons from Debris Handling and Removal.

\begin{tabular}{|c|c|c|}
\hline Nucl ide & $\begin{array}{l}\text { Activity in } \\
\text { water film } \\
(\mu \mathrm{C} / \mathrm{L})^{\star}\end{array}$ & $\begin{array}{c}\text { Total emissions } \\
(\mathrm{Cl})^{\star \star}\end{array}$ \\
\hline$A m-241$ & $1.60 E+00$ & $5.29 E-04$ \\
\hline $\mathrm{Ce}-144$ & $5.29 E+01$ & $1.75 E-02$ \\
\hline Co-60 & $5.47 E+00$ & $1.81 E-03$ \\
\hline$C_{s-134}$ & $2.48 E-01$ & $8.17 E-05$ \\
\hline Cs-137 & $3.91 E+01$ & $1.29 \mathrm{E}-02$ \\
\hline $\mathrm{H}-3$ & $3.90 \mathrm{E}+01$ & $1.29 \mathrm{E}-02$ \\
\hline$K-40$ & 2.04 E-03 & 6.73 E-07 \\
\hline$M n-54$ & $1.51 \mathrm{E}-02$ & 4.97 E-06 \\
\hline$P u-238$ & $3.57 E+00$ & $1.18 E-03$ \\
\hline$P u-239 / 240$ & $2.24 E+01$ & $7.39 E-03$ \\
\hline$P u-241$ & $4.75 E+02$ & $1.57 \mathrm{E}-01$ \\
\hline$R u-106$ & $1.53 E+01$ & $5.04 E-03$ \\
\hline$S b-125$ & $2.70 E+00$ & 8.92 E-04 \\
\hline $5 r-90$ & $3.59 E+02$ & $1.19 \mathrm{E}-01$ \\
\hline$U-234$ & $6.66 \mathrm{E}-02$ & $2.20 E-05$ \\
\hline$U-235$ & $1.21 E-02$ & 3.99 E-06 \\
\hline$U-238$ & $5.42 E-02$ & $1.79 E-05$ \\
\hline
\end{tabular}

*Assumes resuspension of all sediment and disperston into water of all deposits on hardware. 330 liters.

**Assumes a total volume dispersed to air of 
Mechanical cutting methods (e.g., shears, nibblers, and cutters) are expected to produce particles. The particles will include particles of the contaminated surfaces of the hardware. However, there is little motive force (e.g., bubbling) during mechanical cutting to carry these particles to the pool surface, so no significant dispersion of the particles directly to the air space is anticipated. The particles will contribute to the sediment radionuclide inventory, but the contribution is assumed to be small.

Plasma torch cutting is more likely to provide a direct contribution to the air source term via both enhanced evaporation and the dispersion of fume-11ke particles. Plasma torches produce a high-temperature (greater than 11,000 degrees celstus) lonized gas that severs virtually any conductive material (McGough and Knetl 1990). At these temperatures, water both vaporizes and dissociates into hydrogen and oxygen gas, generating bubbles that can carry particulate. Experience with underwater plasma cutting at Three Mile IsIand and Yankee Rowe Nuclear indicates that a very fine particulate is generated, and that some of the particulate is carried to the air-water interface (Appendix $A-3$ ).

The vendor was not aware of any concerns or evaluations related to gaseous radionuclide emisstons. However, the temperatures reported at the cutting surface exceed the boiling point of the radionuclides in the basin, so vaporization of the radionuclides was evaluated (Appendix B). Even with a worst-case evaluation of the heat energy generated by plasma torch cutting and the heat capacity of the surrounding water, the temperature of the water would decrease rapidly with distance from the torch. Assuming that all of the energy supplied to the torch is transferred into heating the water and that the torch is used continuousiy for 8 hours, the maximum temperature observed 5 feet from the cutting surface would be less than 100 degrees celsius. Cutting will be performed at depths of 20 feet or greater. Therefore, any radionuclides volatilized at the cutting surface will recondense before contacting the air.

Additional results of the thermal evaluation in Appendix $B$ include the following.

- The maximum amount of water that could be heated to 100 degrees celsius during cutting would be approximately 14,000 liters.

- The maximum amount of additional water that could be evaporated would be approximately 1,700 1iters. Additional evaporation due to plasma torch cutting is included in the assumed evaporation rate as discussed earlier.

The quantity of particulate generated by plasma torch cutting assumes the following.

- The kerf (the groove made by cutting) is 0.5 inch wide.

- The hardware that might be cut consists of process tubes, all structural steel (including the sorting table), and the fuel baskets. 
- Equipment is cut into 3-foot lengths. Assuming that mass is proportional to length, the mass of the kerf is then about 1.4 percent of the total mass of the hardware.

- All of the mass associated with the kerf converts to particulate.

In determining the emissions to the air space based on GEJ, it was additionally assumed that 10 percent of the resulting particulate reaches the surface of the pool and is dispersed into the air space by bubbles. The activity of the particulate is assumed to be the activity of the hardware per unit mass presented in Table 2-1. Table 3-2 presents the resulting source term.

Hydroscrubbing. A ring consisting primarily of mineral deposits and algae is present on the walls of the storage pools at the air-water interface. During stabilization, a stream of high-pressure water discharged at about 20 gallons per minute will be directed at the ring to wash the material down into the basin water. The water source is likely to be filtered basin water. Aerosol generated from hydroscrubbing could contribute to the source term.

Hydroscrubbing procedures are designed to minimize splashback and mist generation. In the case of the basin, the water stream will be aimed at a point on the wall approximately 0.5 feet above the air-water interface. The spray nozzle will be located about 6 to 8 inches from the wall and angled downwards about 33 degrees. In the past, using similar techniques at 100 Area facilities, the aerosol produced was so slight and localized that operators positioned 10 to 20 feet away from the impact point did not require respiratory protection, and visibility was only slightly impaired (Appendix A-4). used.

To determine the emissions, the following parameters and assumptions were

- The perimeter of the storage pools in the basin measures 280 meters (914 feet).

- The air space for a distance of 1 meter ( 3 feet) above the water surface and 2 meters ( 6 feet) out from the wall is assumed to become laden with aerosol, and all of the aerosol from this volume contributes to the air space source term.

- The aerosol loading in the affected air volume is assumed to be 1,000 milligrams per cubic meter (the equivalent of a heavy fog). Based on the past experience cited above, the assumption of aerosol loading approximating a heavy fog is conservative. However, it provides a bounding case for this analysis.

- The solid deposits on the basin walls are assumed to be similar to the basin sediment in terms of isotope type and activity. The aerosol droplets are assumed to contain 500 parts per million by weight of these solids, a loading similar to that assumed for the film on hardware removed from the basin. The activity of the water in the aerosol is assumed to be that of basin water. 
Table 3-2. Emissions from Plasma Torch Cutting.

\begin{tabular}{|c|c|c|}
\hline Nucl ide & $\begin{array}{c}\text { Total activity } \\
\text { in cut hardware } \\
(\mathrm{Ci})^{\star}\end{array}$ & $\begin{array}{c}\text { Total emissions } \\
(\mathrm{Ci})^{\star \star}\end{array}$ \\
\hline$A m-241$ & $2.69 E+00$ & 3.77 E-03 \\
\hline Ce-144 & $9.57 E+01$ & $1.34 E-01$ \\
\hline Co-60 & $4.77 E+00$ & $6.67 E-03$ \\
\hline Cs-134 & 4.40 E-01 & 6.16 E-04 \\
\hline Cs-137 & $6.77 \mathrm{E}+01$ & 9.48 E-02 \\
\hline$H-3 * * \star$ & & 6.62 E-02 \\
\hline \multicolumn{3}{|l|}{$K-40$} \\
\hline$M n-54$ & $1.30 \mathrm{E}-02$ & 1.82 E-05 \\
\hline$P u-238$ & $5.98 E+00$ & $8.38 E-03$ \\
\hline $\mathrm{Pu}-239 / 240$ & $3.76 E+01$ & $5.27 \quad E-02$ \\
\hline $\mathrm{Pu}-241$ & $7.98 E+02$ & $1.12 E+00$ \\
\hline$R u-106$ & $2.76 E+01$ & 3.87 E-02 \\
\hline Sb-125 & $4.27 E+00$ & $5.97 E-03$ \\
\hline$S r-90$ & $6.56 \mathrm{E}+01$ & 9.19 E-02 \\
\hline$U-234$ & 1.12 E-01 & $1.57 \mathrm{E}-04$ \\
\hline U-235 & 2.03 E-02 & $2.84 E-05$ \\
\hline$U-238$ & $9.11 \quad E-02$ & 1.28 E-04. \\
\hline
\end{tabular}

*Cut hardware assumed to include fuel baskets, dump cart assemblies, sorting tray, dump basket, and process tubes. Total mass approximately 45,000 kilograms. Activity per unit mass Table 2-2. **Assumes 1.4 percent of mass becomes particulate, and 10 percent of particulate released to air at air-water interface. twotritium from additional 1,700 liters evaporation during cutting. 
If all of the aerosol were to be condensed it would be equivalent to 0.6 liter of water containing 500 parts per million by weight of suspended solids. The emissions are presented in Table 3-3.

Projected annual abated emissions based on the engineering evaluations identified in the above information are presented in Table 3-4. In addition to the above information, the following assumptions were made.

- The debris washing, packaging, and removal activities are assumed to occur over a 2-year period. The source term to the basin air space from these activities was therefore divided by two for the annual release.

- The source terms from plasma torch cutting and hydroscrubbing were assumed to occur during a 1-year period.

- The HEPA filter is assumed to have an installed removal efficiency for particulate of 99.95 percent.

3.2.2.1 Operating Mode. For purposes of the release evaluations, the debris handling and removal activities are assumed to occur over a period of 2 years. It is assumed that hardware cutting and hydroscrubbing will also occur during one of those 2 years, so that all activities contribute concurrently to the worst-case annual emission. The actual time spent cutting and hydroscrubbing is expected to be on the order of hours.

\subsubsection{CFR 61, Appendix D, Methodology}

This section provides the release rates calculated using 40 CFR 61 , Appendix $D$ Methodology. It is presented as information only.

Table 3-5 presents the projected annual emissions from the basin stabilization project using 40 CFR 61, Appendix D Methodology.

The radionuclides used in this projection are those identified previously as representing the activity associated with the water, sediment, hardware, and fuel element fragments (Table 2-4). The following assumptions were used.

- A physical adjustment factor of 1 was applied to all tritium.

- A physical adjustment factor of 1 was applied to the activity in 25 percent (by weight) of the hardware that will be cut (approximately 45,000 kilograms of hardware). This is based on the assumption that the plasma torch will heat the metal for approximately 4 inches on either side of the cutting point to 100 degrees celsius or greater.

- A physical adjustment factor of 1 was applied to the activity in 14,000 liters of water. This is the maximum amount of water that could be heated to 100 degrees celsius or greater if a plasma torch is used (Appendix A). 
Table 3-3. Emissions from Hydroscrubbing.

\begin{tabular}{|l|c|c|}
\hline \multicolumn{1}{|c|}{ Nuclide } & $\begin{array}{c}\text { Aerosol with } \\
\text { solids } \\
(\mu \mathrm{C} \mathrm{i} / \mathrm{L})^{*}\end{array}$ & $\begin{array}{c}\text { Total emissions } \\
(\mathrm{C} \mathrm{i})^{\star *}\end{array}$ \\
\hline $\mathrm{Am}-241$ & $1.60 \mathrm{E}+00$ & $9.62 \mathrm{E}-07$ \\
\hline $\mathrm{Ce}-144$ & $5.29 \mathrm{E}+01$ & $3.17 \mathrm{E}-05$ \\
\hline $\mathrm{Co}-60$ & $5.47 \mathrm{E}+00$ & $3.28 \mathrm{E}-06$ \\
\hline $\mathrm{Cs}-134$ & $2.48 \mathrm{E}-01$ & $1.49 \mathrm{E}-07$ \\
\hline $\mathrm{Cs}-137$ & $3.91 \mathrm{E}+01$ & $2.35 \mathrm{E}-05$ \\
\hline $\mathrm{H}-3$ & $3.90 \mathrm{E}+01$ & $2.34 \mathrm{E}-05$ \\
\hline $\mathrm{K}-40$ & $2.04 \mathrm{E}-03$ & $1.22 \mathrm{E}-09$ \\
\hline $\mathrm{Mn}-54$ & $1.54 \mathrm{E}-02$ & $9.04 \mathrm{E}-09$ \\
\hline $\mathrm{Pu}-2.38$ & $3.57 \mathrm{E}+00$ & $2.14 \mathrm{E}-06$ \\
\hline $\mathrm{Pu}-239 / 240$ & $2.24 \mathrm{E}+01$ & $1.34 \mathrm{E}-05$ \\
\hline $\mathrm{Pu}-241$ & $4.75 \mathrm{E}+02$ & $2.85 \mathrm{E}-04$ \\
\hline $\mathrm{Ru}-106$ & $1.53 \mathrm{E}+01$ & $9.17 \mathrm{E}-06$ \\
\hline $\mathrm{Sb}-125$ & $2.70 \mathrm{E}+00$ & $1.62 \mathrm{E}-06$ \\
\hline $\mathrm{Sr}-90$ & $3.59 \mathrm{E}+02$ & $2.16 \mathrm{E}-04$ \\
\hline $\mathrm{U}-234$ & $6.66 \mathrm{E}-02$ & $4.00 \mathrm{E}-08$ \\
\hline $\mathrm{U}-235$ & $1.21 \mathrm{E}-02$ & $7.25 \mathrm{E}-09$ \\
\hline $\mathrm{U}-238$ & $5.42 \mathrm{E}-02$ & $3.25 \mathrm{E}-08$ \\
\hline
\end{tabular}

*Activity in condensed aerosol, assuming condensed aerosol is equivalent to basin water with approximately 500 parts per million by weight suspended sediment.

**Assumes a total condensed aerosol volume of 0.6 liter. 


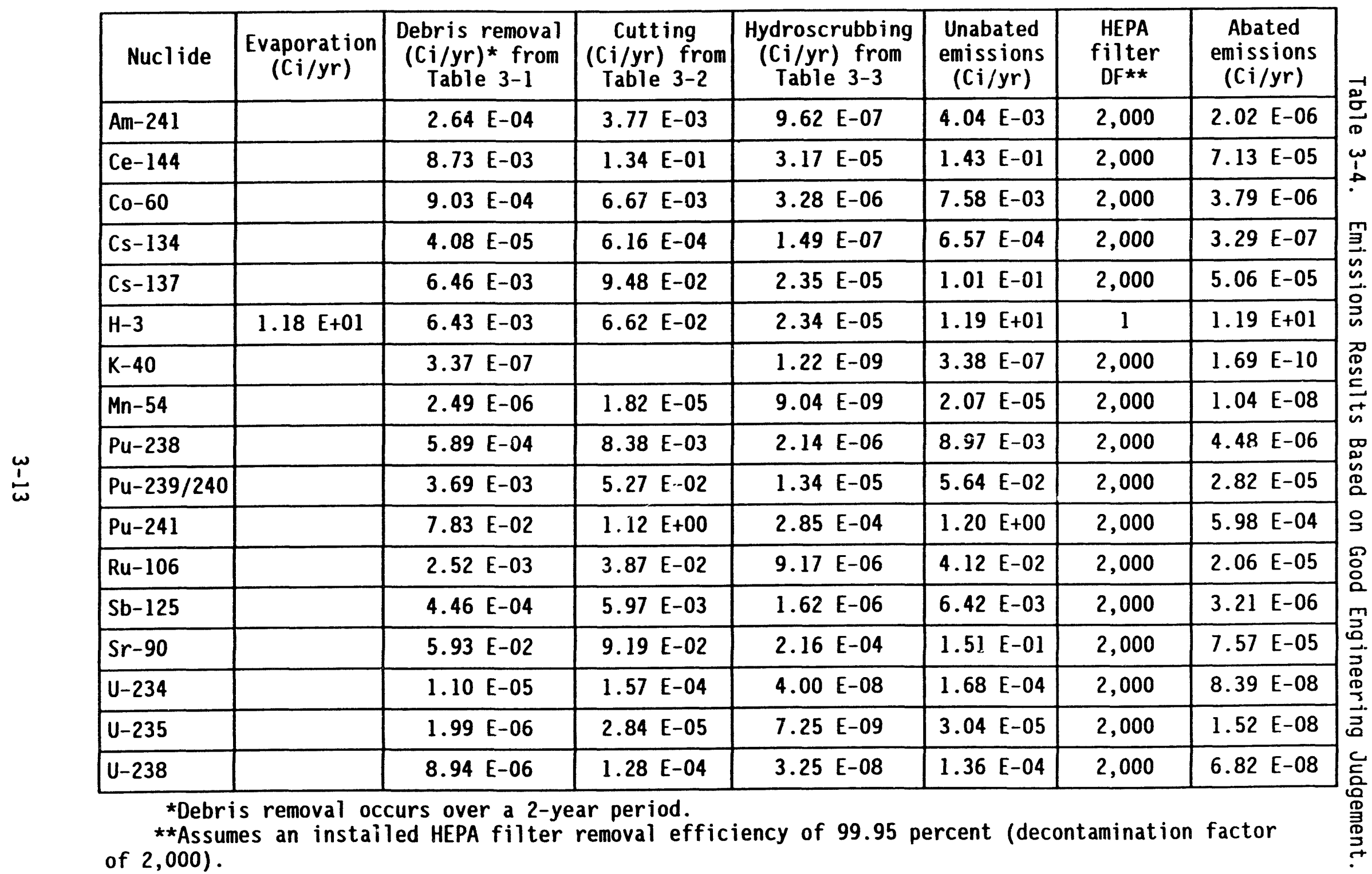




\begin{tabular}{|c|c|c|c|c|c|c|c|c|c|}
\hline Nuclide & $\begin{array}{c}\text { Activity*t} \\
\text { (Ci) above } \\
100^{\circ} \mathrm{C}\end{array}$ & $\begin{array}{l}\text { Release } \\
\text { rate } \\
\text { multiplier }\end{array}$ & 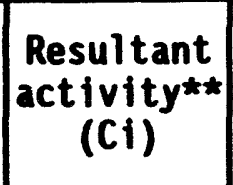 & $\begin{array}{c}\text { Remaining } \\
\text { act ivity } \\
\text { (Ci) }\end{array}$ & $\begin{array}{c}\text { Release } \\
\text { rate } \\
\text { multiplier }\end{array}$ & $\mid \begin{array}{c}\text { Resultant } \\
\text { activity* } \\
\text { (Ci) }\end{array}$ & $\begin{array}{c}\text { Total } \\
\text { emission } \\
\text { rate } \\
(\mathrm{Ci} / \mathrm{yr})^{\star \star \star}\end{array}$ & $\begin{array}{c}\text { HEPA } \\
\text { adjustment } \\
\text { factor }\end{array}$ & $\begin{array}{c}\text { Total } \\
\text { emissions } \\
(C 1 / y r)\end{array}$ \\
\hline$A m-241$ & $6.73 \mathrm{E}-01$ & 1 & $6.73 \mathrm{E}-01$ & $9.34 E+00$ & 0.001 & $9.34 \mathrm{E}-03$ & $6.82 \mathrm{E}-01$ & 0.01 & $6.82 \mathrm{E}-03$ \\
\hline $\mathrm{Ce}-144$ & $2.39 E+01$ & 1 & $2.39 E+01$ & $3.15 E+02$ & 0.001 & $3.15 \mathrm{E}-01$ & $2.42 \mathrm{E}+01$ & 0.01 & $2.42 \mathrm{E}-01$ \\
\hline $\mathrm{CO}_{0}-60$ & $1.19 E+00$ & 1 & $1.19 E+00$ & $2.13 \mathrm{E}+01$ & 0.001 & $2.13 \mathrm{E}-02$ & $1.21 E+00$ & 0.01 & $1.21 \mathrm{E}-02$ \\
\hline Cs-134 & $1.10 \mathrm{E}-01$ & 1 & $1.10 \mathrm{E}-01$ & $5.64 E+00$ & 0.001 & $5.64 \mathrm{E}-03$ & $1.16 \mathrm{E}-01$ & 0.01 & $1.16 \mathrm{E}-03$ \\
\hline Cs-137 & $1.69 E+01$ & 1 & $1.69 E+01$ & $8.71 E+02$ & 0.001 & $8.71 \mathrm{E}-01$ & $1.78 \mathrm{E}+01$ & 0.01 & $1.78 E-01$ \\
\hline $\mathrm{H}-3$ & $5.45 \mathrm{E}-01$ & 1 & $5.45 \mathrm{E}-01$ & $2.99 E+02$ & 1 & $2.99 \mathrm{E}-01$ & $3.00 E+02$ & 1 & $3.00 \mathrm{E}+02$ \\
\hline$K-40$ & $2.86 E-05$ & 1 & $2.86 \mathrm{E}-05$ & $8.34 \mathrm{E}-03$ & 0.001 & $8.34 E-06$ & $3.69 E-05$ & 0.01 & $3.69 \mathrm{E}-07$ \\
\hline$M n-54$ & $3.26 E-03$ & 1 & $3.26 \mathrm{E}-03$ & $5.85 E-02$ & 0.001 & $5.85 \mathrm{E}-05$ & $3.32 \mathrm{E}-03$ & 0.01 & $3.32 E-05$ \\
\hline$P u-238$ & $1.50 E+00$ & 1 & $1.50 \mathrm{E}+00$ & $2.10 E+01$ & 0.001 & $2.10 \mathrm{E}-02$ & $1.52 \mathrm{E}+00$ & 0.01 & $1.52 \mathrm{E}-02$ \\
\hline $\mathrm{Pu}-239 / 240$ & $9.40 E+00$ & 1 & $9.40 \mathrm{E}+00$ & $1.30 \mathrm{E}+02$ & 0.001 & $1.30 \mathrm{E}-01$ & $9.53 \mathrm{E}+00$ & 0.01 & $9.53 \mathrm{E}-02$ \\
\hline $\mathrm{Pu}-241$ & $1.99 E+02$ & 1 & $1.99 E+02$ & $2.76 E+03$ & 0.001 & $2.76 \mathrm{E}+00$ & $2.02 E+02$ & 0.01 & $2.02 E+00$ \\
\hline$R u-106$ & $6.90 E+00$ & 1 & $6.90 \mathrm{E}+00$ & $9.09 \mathrm{E}+01$ & 0.001 & $9.09 \mathrm{E}-02$ & $6.99 E+00$ & 0.01 & $6.99 \mathrm{E}-02$ \\
\hline Sb-125 & $1.07 E+00$ & 1 & $1.07 E+00$ & $1.00 \mathrm{E}+01$ & 0.001 & $1.00 \mathrm{E}-02$ & $1.08 E+00$ & 0.01 & $1.08 \mathrm{E}-02$ \\
\hline $5 r-90$ & $1.65 E+01$ & 1 & $1.65 E+01$ & $2.16 E+03$ & 0.001 & $2.16 E+00$ & $1.86 \mathrm{E}+01$ & 0.01 & $1.86 \mathrm{E}-01$ \\
\hline$U-234$ & $2.80 \mathrm{E}-02$ & 1 & $2.80 \mathrm{E}-02$ & $3.88 \mathrm{E}-01$ & 0.001 & $3.88 \mathrm{E}-04$ & $2.84 \mathrm{E}-02$ & 0.01 & $2.84 \mathrm{E}-04$ \\
\hline$U-235$ & $5.08 \mathrm{E}-03$ & 1 & $5.08 \mathrm{E}-03$ & $7.03 \mathrm{E}-02$ & 0.001 & $7.03 \mathrm{E}-05$ & $5.15 \mathrm{E}-03$ & 0.01 & $5.15 \mathrm{E}-05$ \\
\hline$U-238$ & $2.28 \quad E-02$ & 1 & $2.28 \mathrm{E}-02$ & $3.15 \mathrm{E}-01$ & 0.001 & $3.15 \mathrm{E}-04$ & $2.31 \mathrm{E}-02$ & 0.01 & $2.31 \mathrm{E}-04$ \\
\hline \multicolumn{10}{|c|}{$\begin{array}{l}\star \text { Less than } 100^{\circ} \mathrm{C} \text {. Includes all of the activity in the sediment, fuel elements, and hardware } \\
\text { that will not be cut; activity in all water minus } 1,400 \text { liters; and } 75 \text { percent of the activity in } \\
\text { hardware that will be cut. } \\
\star \star H e a t e d \text { to } 100^{\circ} \mathrm{C} \text { or greater. Includes activity in } 14,000 \text { liters of water and } 25 \text { percent of } \\
\text { hardware above } 100^{\circ} \mathrm{C} \text { and the remaining activity. } \\
\star \star \star \text { Sum of the activity. } \\
\text { HEPA = high-efficiency particulate air (filter). }\end{array}$} \\
\hline
\end{tabular}


- A physical adjustment factor of 0.001 was applied to all sediment, because the sediment exists as solid particulate.

- A physical adjustment factor of 0.001 was applied to all activity associated with the hardware that will not be heated to greater than 100 degrees celsfus, including hardware that will not be cut (approximately 57,000 kilograms of the total) 75 percent (by weight) of the hardware that will be cut.

- A physical adjustment factor of 0.001 was applied to the radionuclide inventory associated with the fuel element and target fragments. Although this inventory is in a solid form, the fragments are subject to corrosion and dispersion as solid particulate.

- An emissions control adjustment factor of 0.01 was applied to all radionuclides except tritium to account for the use of HEPA filters.

\subsection{OFFSITE DOSES}

The Clean Air Assessment Package 1988 (CAP-88) computer code was used to calculate the effective dose equivalent (EDE) from the proposed basin stabilization project to the offsite maximaliy exposed individual (MEI), according to requirements of 40 CFR 61 .

\subsubsection{Input Data Used}

CAP-88, an U.S. Environmental Protection Agency (EPA)-approved code package, has the capability to model both ground-level and elevated airborne releases from locations in the 100, 200 East, 200 West, and 300 Areas. The model calculates EDE to an individual member of the public using Hanford Site meteorological data. Doses from radioactive daughter products of primary radionuclides are included.

A CAP-88 evaluation was run specifically for the projected releases of basin emissions from the $116 \mathrm{~N}$ stack. Input parameters and detailed analyses are provided in Appendix $C$. The resulting dose factors for a l-curie release are provided in Table 3-6.

\subsubsection{Results}

Table 3-6 provides the total projected EDE from abated airborne emissions (based on GEJ) resulting from basin stabilization activities. The total projected EDE to the offsite MEI from abated emissions is $0.0002 \mathrm{milli}$ rem/year. The dose attributable to radiological emissions from the basin stabilization project will contribute 0.002 percent of the 40 CFR 61 EDE regulatory 1 imit of $10 \mathrm{mill}$ irem/year to the offsite MEI. 
Table 3-6. Effective Dose Equivalent to Individual Receiving Maximum Exposure to Radiological Emissions Based on Good Engineering Judgement.

\begin{tabular}{|c|c|c|c|c|}
\hline Nuclide & $\begin{array}{l}\text { Abated } \\
\text { emission } \\
(C 1 / y r)\end{array}$ & $\begin{array}{l}\text { Modeled dose } \\
\text { factor } \\
\text { (mrem/Ci)* }\end{array}$ & $\begin{array}{l}\text { Abated } \\
\text { MEI dose } \\
\text { (mrem/yr) }\end{array}$ & $\begin{array}{c}\text { \% of abated } \\
\text { MEI dose }\end{array}$ \\
\hline$A_{n}-241$ & 2.02 E-06 & $4.25 E+00$ & $8.57 E-06$ & 3.96 \\
\hline $\mathrm{Ce}-144$ & $7.13 \mathrm{E}-05$ & $4.27 E-03$ & 3.05 E-07 & 0.14 \\
\hline Co-60 & $3.79 \mathrm{E}-06$ & $5.71 \quad E-01$ & $2.16 E-06$ & 1.00 \\
\hline Cs-134 & $3.29 \quad E-07$ & 3.14 E-02 & $1.03 \mathrm{E}-08$ & 0.00 \\
\hline Cs-137 & $5.06 E-05$ & $5.96 E-02$ & $3.02 E-06$ & 1.40 \\
\hline $\mathrm{H}-3$ & $1.19 E+01$ & $6.98 E-06$ & $8.29 E-05$ & 38.30 \\
\hline$k-40$ & $1.69 E-10$ & $4.53 E-02$ & 7.65 E-12 & 0.00 \\
\hline$M n-54$ & 1.04 E-08 & $3.65 E-03$ & $3.78 \mathrm{E}-11$ & 0.00 \\
\hline$P u-238$ & $4.48 E-06$ & $2.58 E+00$ & $1.16 E-05$ & 5.35 \\
\hline$P u-239 / 240$ & $2.82 E-05$ & $2.78 E+00$ & 7.83 E-05 & 36.22 \\
\hline$P u-241$ & $5.98 \quad E-04$ & $4.39 \mathrm{E}-02$ & $2.62 E-05$ & 12.13 \\
\hline$R u-106$ & $2.06 \mathrm{E}-05$ & 5.57 E-03 & $1.15 \mathrm{E}-07$ & 0.05 \\
\hline$S b-125$ & $3.21 E-06$ & $5.87 E-03$ & $1.88 E-08$ & 0.01 \\
\hline$S r-90$ & $7.57 E-05$ & $3.86 \mathrm{E}-02$ & 2.92 E-06 & 1.35 \\
\hline$U-234$ & $8.39 E-08$ & $1.04 E+00$ & $8.72 \quad E-08$ & 0.04 \\
\hline U-235 & $1.52 E-08$ & $9.93 \mathrm{E}-01$ & $1.51 E-08$ & 0.01 \\
\hline$U-238$ & $6.82 E-08$ & $1.14 E+00$ & $7.81 \quad E-08$ & 0.04 \\
\hline & & TOTAL & 2.16 E-04 & 100.00 \\
\hline
\end{tabular}

*Clean Air Assessment Package 1988 dose estimates for releases from a 200-foot stack for an individual located $14.7 \mathrm{kilometers} \mathrm{east} \mathrm{of}$

$100 \mathrm{~N}$ (equivalent to actual offsite location $11.5 \mathrm{kilometers}$ west). MEI - maximally exposed individual. 
For comparison, the total projected EDE to the offsite MEI using 40 CFR 61. Appendix D, Methodology is $0.477 \mathrm{~m} 111$ irem/year and is presented in Table 3-7. The radionuclides listed include those that could contribute 10 percent or more of thio EDE to the MEI.

The dose resulting from all Hanford Site operations in 1992, was determined to be $0.004 \mathrm{milli}$ rem/year (PNL 1993). The emissions (based on GEJ) as a result of a full year's stabllization activities at the basin, in conjunction with previous operations at the Hanford Site, will not result in a violation of the National emiss:is Standard of $10 \mathrm{mill}$ irem/year ( 40 CFR 61). 
Table 3-7. Effective Dose Equivalent to Individual Receiving Maximum Exposure to Radiological Emissions (based on 40 CFR 61, Appendix D Methodology).

\begin{tabular}{|c|c|c|c|}
\hline Nuclide & $\begin{array}{c}\text { Total } \\
\text { emisstons } \\
\text { (CI/yr) }\end{array}$ & $\begin{array}{c}\text { Modeled dose } \\
\text { factor } \\
(\text { mrem } / C 1)^{\star}\end{array}$ & $\begin{array}{c}\text { Appendix D } \\
\text { dose } \\
\text { (mrem/yr) }\end{array}$ \\
\hline$A m-241$ & 6.82 E-03 & $4.25 E+00$ & 2.90 E-02 \\
\hline$C e-144$ & $2.42 E-01$ & $4.27 E-03$ & $1.03 E-03$ \\
\hline Co-60 & $1.21 \mathrm{E}-02$ & $5.71 E-01$ & $6.85 E-03$ \\
\hline Cs-134 & $1.16 \mathrm{E}-03$ & $3.14 \mathrm{E}-02$ & 3.64 E-05 \\
\hline Cs-137 & $1.78 \quad E-01$ & $5.96 \quad E-02$ & 1.06 E-02 \\
\hline $\mathrm{H}-3$ & $3.00 E+02$ & $6.98 E-06$ & $2.09 E-03$ \\
\hline$k-40$ & 3.69 E-07 & 4.53 E-02 & $1.67 E-08$ \\
\hline$M n-54$ & 3.32 E-05 & $3.65 E-03$ & $1.21 E-07$ \\
\hline$P u-238$ & $1.52 E-02$ & $2.58 E+00$ & $3.92 E-02$ \\
\hline$P u-239 / 240$ & 9.53 E-02 & $2.78 E+00$ & $2.65 E-01$ \\
\hline$P u-241$ & $2.02 E+00$ & $4.39 E-02$ & 8.87 E-02 \\
\hline$R u-106$ & 6.99 E-02 & $5.57 E-03$ & $3.89 E-04$ \\
\hline$S b-125$ & $1.08 E-02$ & $5.87 E-03$ & $6.34 E-05$ \\
\hline$S r-90$ & $1.86 E-01$ & $3.86 E-02$ & $3.32 E-02$ \\
\hline U-234 & $2.84 E-0.4$ & $1.04 E+00$ & $2.95 E-04$ \\
\hline U-235 & $5.15 E-05$ & $9.93 \mathrm{E}-01$ & $5.11 E-05$ \\
\hline$U-238$ & $2.31 E-04$ & $1.14 E+00$ & $2.63 E-04$ \\
\hline & & Tota? & $4.77 E-01$ \\
\hline
\end{tabular}

- Clean Air Assessment Package 1988 dose estimates for releases from a 200-foot stack for an individual located $14.7 \mathrm{k} f$ lometers east of $100 \mathrm{~N}$ (equivalent to actual offsite location $11.5 \mathrm{k}$ (lometers west). 


\subsection{REFERENCES}

40 CFR 61, "National Emission Standards for Hazardous A1r Pollutants," Title 40, Code of Federal Regulations, Part 61, U.S. Environmental Protection Agency, Washington, D.C.

McGough, M. S., and G. J. Knetl/PCI Energy Services, 1990, "Underwater Plasma Cutting of the Lower Core Assembly and Metallurgical Sample of the Bottom Head at Three Mile Island Unit 2," Excellent and economic Nuclear Plant Performance, NE-Vol. 4, Book No. 100305.

Myott, E. M., 1993, 105N Basin Airflow Test Report, WHC-SD-NR-TRP-018.

PNL, 1993, Hanford Site Environmental Report for Calendar Year 1992, June 1993, PNL-8682, UC-602, Pacific Northwest Laboratory, Richland, Washington.

Subrahmanyam, V. B., 1988, Hanford Production Reactor Fuel Storage Basin Sediment-Characterization and Processing for Disposal, WHC-SD-TI-135, Rev. 1.

WHC, 1993a, Environmental Division, Environmental Conpliance Manual, WHC-CM-7-5, Rev. 0, Westinghouse Hanford Company, Richland, Washington.

WHC, 1993b, N Reactor Deactivation Progran Plan, December 1993, WHC-SP-0615, Rev. 4, West Inghouse Hanford Company, Richi and, Washington.

WHC, 1993c, Radiation Control Manual, WHC-CM-1-6, Westinghouse Hanford Company, Richland, Washington.

WAC 246-247, 1992, "Radiation Protection-Air Emissions," Washington Adninistrative Code, as amended. 
DOE/RL-94-15, Rev. 0

This page intentionally left blank. 
DOE/RL-94-15, Rev. 0

APPENOIX $A-1$

CORRESPONDENCE - N REACTOR EFFLUENT PROJECTION

APP A-1-1 
DOE/RL-94-15, Rev. 0

This page intentionally left blank.

APP A-1-11 
From: $\quad$ N Reactor Deactivation

Phone: $\quad 373-4164$

Date: November 19, 1993

SUbject: N REACTOR EFFLUENT PROJECTION

To:

Gary Wells
cc: Warren Cohen
Ella Coenberg
Jerry Hunacok
J. L. Laureni
Chris Lucas
F. M. McDonal

$H 6-26$

$H 6-26$

$H 6-25$

$10-4 !$

$\mathrm{R} 2-7 \mathrm{7}$

$.10-35$

F. M. McDonale

$83-45$
M. R. Morton
B. D Scnliperoort
Jerr. Tumbaman
Jonn a d: ="
Dave vil: :." -

$22 \cdot ?$

$18-20$

10.29

16.

$\therefore \vdots$

$\therefore: \vdots$

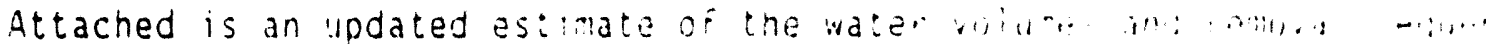

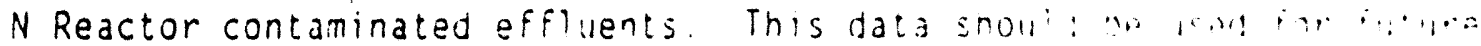

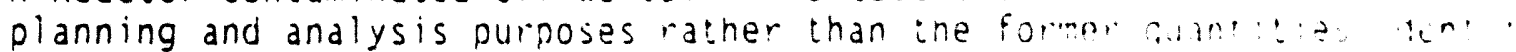
in the BAT documents.

Should you have any questions please contact John Walsh (3?3-1408) of $m$; staff.

(a) Jfector

for R. J. Gimera

$N$ Reactor Manager

$a k$

at tachment 
N REACTOR DEACTIVATION

WATER VOLUME/REMOVAL QUANTITIES

PROGRAM SUMMARY

Thousands of Gallons

\begin{tabular}{|c|c|c|c|c|c|}
\hline & $F Y-94$ & $F Y-95$ & $F Y-96$ & $F Y-97$ & SUMMARY \\
\hline \multicolumn{6}{|l|}{ •PROGRAM SUMMARY } \\
\hline Fiscal Year Starting Volume & 1603 & 1558 & 1498 & 498 & 1603 \\
\hline $\begin{array}{l}\text { Misc. (leaks to sumps, } \\
\text { etc.) }\end{array}$ & 10 & 10 & 10 & 0 & 30 \\
\hline Evaporation & $(292)$ & $(292)$ & (292) & $(61)$ & $1937)$ \\
\hline Water Additions - Makeup & 232 & 202 & 200 & 10 & 644 \\
\hline Water Additions - Decon & 5 & 20 & 15 & 10 & $5 \dot{0}$ \\
\hline Volume Subtotal & 1558 & 1498 & 1431 & 457 & $\because \therefore$ \\
\hline Removal volume & 0 & 0 & $(933)$ & $(457)$ & (1:390: \\
\hline Fiscal Year End Volume & 1553 & 1498 & $4 \leqq 8$ & 0 & \\
\hline
\end{tabular}

* Does not include clearivell, potable water, or fire system water. Since these are not contaminated, they will discharge to the NPDES permitted outfall $\left(009^{\circ}\right)$. 
N REACTOR DEACTIVATION

WATER VOLUME/REMOVAL QUANTITIES

Thousands of Gallons

\begin{tabular}{|c|c|c|c|c|c|}
\hline & $F Y-94$ & FY-95 & $F Y-96$ & FY-97 & SUMMARY \\
\hline \multicolumn{6}{|l|}{ PROGRAM SCHEDULE DATES } \\
\hline \multicolumn{6}{|l|}{ Drain Fuel Basins } \\
\hline \multicolumn{6}{|l|}{$\begin{array}{l}\text { Transfer other pits/sumps/ } \\
\text { piping to Lift Station }\end{array}$} \\
\hline \multicolumn{6}{|l|}{ Drain Lift Station } \\
\hline \multicolumn{6}{|l|}{$\begin{array}{l}\text { Drain/Remove Emergency Dump } \\
\text { Basin }\end{array}$} \\
\hline \multicolumn{6}{|l|}{ * WATER VOLUME \& REMOVAL } \\
\hline \multicolumn{6}{|l|}{ FUEL BASIN COMPLEX } \\
\hline Fiscal vear Startina vol. & 1000 & 955 & 895 & 0 & $\therefore:$ \\
\hline Evaporation & $(80)$ & $(80)$ & $180 !$ & i. & $\therefore$ \\
\hline Water Addition - Make-uc & 30 & 0 & 0 & 0 & 30 \\
\hline Water Addition - Decon & 5 & 20 & 15 & 0 & 40 \\
\hline Volume Subtotal & 955 & 895 & 830 & 0 & $N, \hat{\sim}$ \\
\hline Removal Volume & $\underline{0}$ & 0 & $(830)$ & 0 & $(830)$ \\
\hline Fiscal Year End Volume & 955 & 895 & 0 & 0 & 0 \\
\hline \multicolumn{6}{|l|}{ LIFT STATION } \\
\hline Fiscal Year Starting Vol. & 15 & 15 & 15 & 23 & 15 \\
\hline Evaporation & (2) & $(2)$ & (2) & $(1)$ & $! ?$ \\
\hline Water Addition - Make-up & 2 & 2 & 0 & 0 & 1 \\
\hline Volume Subtotal & 15 & 15 & 13 & $? ?$ & ii $\therefore$ \\
\hline $\begin{array}{l}\text { Transfer from -Misc. } \\
\text { leaks etc. }(10) \text {; Sumps }(35) \text { closu } \\
\text { Evao. of } 3 \text { ) }\end{array}$ & 0 & 0 & 42 & $?$ & $:$ \\
\hline $\begin{array}{l}\text { Transfer from - ' } \mathrm{C} \text { ' } \mathrm{Pit} \\
(63 \text { less evao. of } 5)\end{array}$ & 0 & 0 & 38 & 0 & 38 \\
\hline Transfer from - Piping & 0 & $\underline{0}$ & 25 & 35 & 60 \\
\hline $\begin{array}{l}\text { Water Addition - Rod Room } \\
\text { Pit (10 less evap. of } 2 \text { ) }\end{array}$ & 0 & 0 & 8 & 0 & 8 \\
\hline Available for Removal & 15 & 15 & 126 & 57 & $N / A$ \\
\hline Removal volume & 0 & 0 & 103 & $(57)$ & $(160)$ \\
\hline Fiscal Year End Volume & 15 & 15 & 23 & 0 & 0 \\
\hline
\end{tabular}


N REACTOR DEACTIVATION

WATER VOLUME/REMOVAL QUANTITIES

Thousands of Gallons

\begin{tabular}{|c|c|c|c|c|c|}
\hline & $F Y-94$ & $F Y-95$ & $F Y-96$ & FY- 97 & SUMMAF: \\
\hline \multicolumn{6}{|l|}{ EMERGENCY DUMP BASIN } \\
\hline Fiscal Year Starting Volume & 440 & 440 & 440 & 440 & 440 \\
\hline Evaporation & $(200)$ & $(200)$ & $(200)$ & $(60)$ & $(650)$ \\
\hline Water Addition - Makeup & 200 & 200 & 200 & 10 & 610 \\
\hline Water Addition - Decon & 0 & 0 & 0 & 10 & 10 \\
\hline VOLUME SUBTOTAL & 440 & 440 & 440 & 400 & $N / A$ \\
\hline Removal volume & 0 & 0 & 0 & $(400)$ & $(400)$ \\
\hline Fiscal Year End Volume & 440 & 440 & 440 & 0 & 0 \\
\hline \multicolumn{6}{|l|}{ OTHER PITS/SUMPS/PIPING } \\
\hline $\begin{array}{l}\text { Fiscal Year Starting Vol. } \\
\text { 'C' Pit (43). Piping (60), } \\
\text { Rod Room Pit (10). Sumps (35) } \\
\end{array}$ & 148 & 148 & 148 & 35 & $: \because$ \\
\hline $\begin{array}{l}\text { Misc. (leaks to sumps, } \\
\text { etc.) }\end{array}$ & 10 & 10 & 10 & 0 & 30 \\
\hline Evaporation & $(10)$ & $(10)$ & $(10)$ & $(0)$ & $(30)$ \\
\hline Water Addition - Makeup & 0 & 0 & 0 & 0 & 0 \\
\hline Volume Subtotal & 148 & 148 & 148 & 35 & $N / A$ \\
\hline **Transfer To Lift Station & 0 & 0 & $(113)$ & $(35)$ & $(148)$ \\
\hline Fiscal Year End Volume & 148 & 148 & 35 & 0 & 0 \\
\hline
\end{tabular}

* Does not include non-contaminated clearwell, potable water. or fire system water. These will be discharged to NPDES permilled maifai'

** See Lift Station analysis for removal volume. 
DOE/RL-94-15, Rev. 0

APPENDIX A-2

CORRESPONDENCE - UNDERWATER PLASMA CUTTING

APP $A-2-i$ 
7
7
7
1
1
1

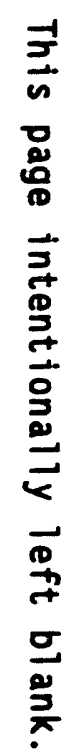

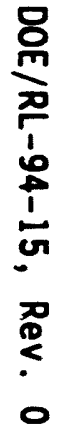


December 21, 1993

\section{Linda Mihalik}

$\mathrm{CH} 2 \mathrm{M}$ Hill

1933 Jadwin

Suite 225

Richland, WA 99352

Subject: Underwater Plasma Cutting

\section{Dear Linda:}

It was a pleasure speaking with you the other day about underwater plasma cutting. $\mathrm{PCl}$ has been involved with this process for the past 14 years. We have worked at nuclear plants such as North Anna, Three Mile Island, Connecticut Yankee, Shoreham, Yankee Rowe, and Fort St. Vrain. In my opinion, we are the leader of underwater plasma cutting in the nuclear industry.

During our conversation you asked me about the particulates which escape into the atmosphere during the underwater plasma cutting process. I spoke with our technicians, who are at Yankee Rowe and are working with the decommissioning of their reactor vessel internals. The following is some information which may be helpful to you.

When plasma cutting under water, $\mathrm{PCl}$ uses a specially designed floating vent hood to trap any particulates which escape into the air. This vent hood has a suction hose which is attached to a Hepa filtration unit. The information for this unit is as follows:

NFS/RPS

Model PFB - 2500 (SP)

Bag in / Bag out

Portable Hepa Filtration. Module

Nominal flow rate 2,000 CFM

The capture velocity range under the hood is $163-230$ feet per minute. Our floating hood size is approximately an 8 foot hexagon. 


\section{FCF}

While at the Yankee Rowe Nuclear Plant, we have experienced the following conditions during the underwater plasma cutting operations.

Components - Reactor vessel internals

Depth of water - 12 feet to 20 feet

Time Range - For 11 weeks the dose rate for the material cut ranged from 1 REM to 15,000 REM. The HEPA filter started a 0 $\mathrm{mRlhr}$ and went to $4 \mathrm{mR} / \mathrm{hr}$ during this time.

Time Range -

In 4 days the dose rate of the material cut ranged from 15,000 REM to 25,000 REM. The HEPA filter dose rate went up to $50 \mathrm{mR} / \mathrm{hr}$. The majority of this increase in the dose rate was caused by the initial cut into the core plate. A significant amount of "crud" was trapped in this plate and was loosened during the initial cutting. A.fine powderlike substance migrated to the surface causing an initial blast of airborne which was all collected by the hood. Other than this burst from the core plate cutting, the HEPA off gas collection was not necessary.

At this time I am not aware of any analysis which has been performed to the HEPA filters.

You also asked me about temperature ranges at the plasma torch. For more technical information I recommend you call Hypertherm, the company from which we purchase the plasma equipment from. Their phone number is $603-643-1441$.

If there is any more information you might require please call me alaneger Proces; coroup

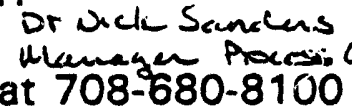
and I will be happy to help you.

Sincerely,

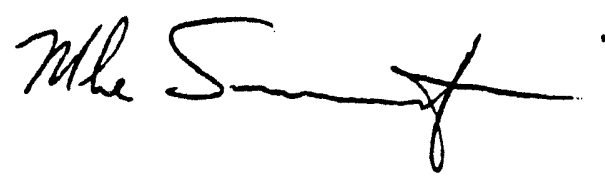

Mike Simundza

Regional Account Manager 
DOE/RL-94-15, Rev. 0

APPENDIX $A-3$

CORRESPONDENCE - IOON FUEL CANISTER ASSAYS

APP $A-3-i$ 
DOE/RL-94-15, Rev. 0

This page intentionally left blank.

APP A-3-11 


\section{Battelle}

Pacllle Norhwert Labopatories
Provided by Dange
Schildenoof.

1213143

Dace July 24, 1990

To J. U. Jernberg

From

Subject

R. L. Brodzinski

$100 \mathrm{~N}$ Fuel Canister Assays

PPDE- $R G_{\text {Axi }}$

Projece Number

Internal Distribution

PR Boolen

Jo Forsythe

$L$ Garret

DL Haggard

RA Larson

RJ Pyzel

File/LB

A total of 11 canisters were neutron counted for residual TRU contamination before and after cleaning. In addition, canisters $\#$ amd $\# 10$ were gamma counted both before and after cleaning which shocild give a reasonably good measure of the decontaminaticn factor afforded by the cleaning process. Assuming the TRU is weapons grade fuel, the first table below gives the TRU concentration before and after cleaning in units of nCi/c net weight of canister for the nine canisters which were nestron counted only. The second table gives both the TRU and the gamma emitters, before ard after, for canisters $\$ 7$ and $\$ 10$. I am enclosing the hardcopies of the data for you to archive. We will archive the data on floppy disc here.

\begin{tabular}{c} 
Canister \\
\hline 2 \\
3 \\
4 \\
5 \\
6 \\
8 \\
9 \\
11 \\
12
\end{tabular}

\begin{tabular}{c} 
TRU before \\
\hline 725 \\
942 \\
493 \\
1020 \\
827 \\
849 \\
1110 \\
453 \\
2680
\end{tabular}

\section{Isotope}

TRU

$54 \mathrm{Mn}$

$\mathrm{rO} \mathrm{Co}$

$125 \mathrm{Sb}$

$137 \mathrm{Cs}$

${ }^{154} \mathrm{Eu}$

155 EU

\section{$\$ 7$ before \\ 989}

4.27

148

198

1330

56.3

$<13$

\section{$\$ 7$ after}

89.8

1.91

67.7

84.8

222

28.4

$<4.2$

$\frac{\text { TzU after }}{32}$
26.9
$<30$
$<30$
9.02
37.3
46.0
$<31$
18.9

\begin{tabular}{ccc}
$\frac{10 \text { before }}{10}$ & & $\frac{10 \text { after }}{46.3}$ \\
\hline 853 & & 0.865 \\
0.994 & $\cdots$ & 31.9 \\
80.3 & & 61.3 \\
89.8 & & 154 \\
387 & & 25.0 \\
46.5 & & $<3.8$ \\
27.6 & &
\end{tabular}


TEST "REPORT OF FEASABILITY STUDY FOR HIGH RRESSURE CLEANTNG OF TUEL CANISTERS

\subsection{INTRODUCTION}

This test was concucted to denonstzate the feasability of using an Aquadyne hydro-blaster to renove the TRU which has accumulated on the $k$ Basin fuel storage canisters during the years of storage. The TRU remalning on the decontaminated canister must be less than the $100 \mathrm{nci} / \mathrm{g}$ limit in order for the canistez to be corsidered non-TRU. The basis for a successful test is that the TRU remaining on tho canisters after decontamination is belc' TRU limits (measured at $90 \%$ confidence).

Environmental and Engineering Demonstracion Laboratory prepared a test pian titlec "Feasabllity study for High Pressure cleaning of Fuel Canisters", WHC-SD-NR-AP-OOI and directed the jesting. Fuel and $K / 0$ operations funded the test and provided operazors and other support. The TRU measurements were made by Battelle Pacific Northwest Laboratories.

The testing started on June 25,1990 and was completed July 24,1990 .

\subsection{DESCRIPTION OF TEST}

Twelve Mark 0 aluminum canistars ware placed in 55 gallon drums. One of the twelve canisters had not been used. Irradiated $N$-Reactor fuel had been stored in the other eleven canisters for several years until it was prccessed by PUREX. The empty canisters were returned and stored in the basins. The canisters which weze used in this zest had been stored at $N$ Basin for a number of years.

The canisters were packaged in plastic, surveyed, and each one was placed in a plastic-lined drum and the lid fastened on. Each drum was labeled with an identification number from one to twelve.

All of the 12 canisters were neutron counted for TRO contamination prior to cleaning. In addition, canisters 7 and $\$ 10$ were gamma counted. Canister $\$ 1$ was the unused canister and counted for the background measurement.

Canisters 77 and $\$ 10$ were each hydro-blasted for 15 minutes. Then the TRU and gamma measurements were taken. Abcut onethird of the visable corrosion products were removed. There was no reduction of the TRU.

Canisters $\frac{\pi}{7}$ and $\frac{10}{* 10}$ were cleaned again. Canister $\$ 7$ was cleaned for about one hour more. The cleaning was 


\section{DRAT}

concontrazed on the inside and inside bottom of the canister. When these canisters were sejneasured, 17 haci a marked reduction of TRC.

After reviewing these results, the cleaning methed was revised. A wize chimney brust. with the same diameter as the canister was obtained to scrub the insides and bottoms of the canisters. It was attached to a power $=i l l$ with an extention about 7 seet in length so scrubioing could take place under water. The canistezs were first scrubbed with the brush on the inside and bottom for several minutes, then hydro-blasted on all the surfaces with the Aquadyne power washer. Total cleaning =ine. for eaci canister was 15 minutes.

Ten of the canisters were cleaned using this procedure. (All of the canisters except $\$ 7$. ) When the cleaning was ccmpleted TRU measurements were taken again.

\subsection{TEST RESULTS}

The residual transuranics on all of the canisters was reduced to less than the TRU limit of $100 \mathrm{nCi} / \mathrm{g}:$ Canister $\$ 7$ had a TRU level of $89.9 \mathrm{nCi} / \mathrm{g}$ after decontamination. It was the only canister wrich had a TRU level close to the limit and was the only one which was not cleaned with the brush prior to the hydro-blasting. The TRU levels remaining on the canisters which were cleaned with the brush prior to hydro-blasting ranged from 9 to $46 \mathrm{nci} / \mathrm{g}$. Table 1 shows the TRU results.

Table 2 Canister TRU Concentration (nCi/g)

\begin{tabular}{c} 
canister \\
\hline 2 \\
3 \\
4 \\
5 \\
6 \\
7 \\
8 \\
9 \\
10 \\
11 \\
12
\end{tabular}

\begin{tabular}{c} 
Before Decon \\
\hline 725 \\
942 \\
493 \\
1020 \\
327 \\
989 \\
849 \\
1110 \\
853 \\
453 \\
2680
\end{tabular}

\begin{tabular}{c} 
Acter. Decon \\
\hline$<32$ \\
26.9 \\
$<30$ \\
$<30$ \\
9.02 \\
89.8 \\
37.3 \\
46.0 \\
46.3 \\
$<31$ \\
18.9
\end{tabular}

Canisters $\$ 7$ and $\# 10$ were also gamma counted. Table 2 shows the gamma emittess before and after decontamination. 


\begin{abstract}
DRAFT
Approximately $75 \%$ of these isotopes were removed from canister 77 and $56 \%$ were removed from canister 10 .
\end{abstract}

Table 2 Gamna Emaitters Bafore and After Decontamination

\section{Isotope}

$\operatorname{Mn}-54$

Co-60

$\mathrm{Sb}-125$

Cs -137

Eu-154

Eu-155

\section{7 before}

4.27
148
198
1330
56.3
$<13$

羔 after

1.91
67.7
84.8
22
28.4
$<4.2$

I10 be fore

0.994

80.3

89.8

387

46.5

27.6
10 after

0.865
31.9
61.3
154
25.0
$<3.8$

4.0 CONCLUSIONS AND RECOMMENJATIONS

This feasability test has shown that the TRU on the canisters can be reduced to less than the TRU limitg of 100 $\mathrm{nC} i / 9$ by the cleaning method described in this test. It is recommended tiat a procedire and criteria be developed to apply this method for use on the remaining canisters. 
DOE/RL-94-15, Rev. 0

\section{APPENDIX A-4}

EFFECTS OF HYDROSCRUBBING 
7
7
1
1
1

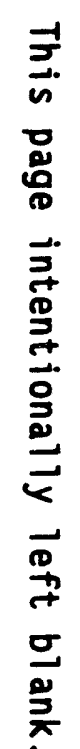

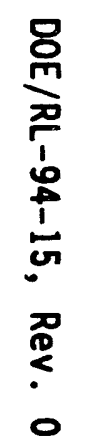


DOE/RL-94-15, Rev. 0

\section{APPENDIX A-4}

\section{EFFECTS OF HYDROSCRUBBING}

\section{CONVERSATION RECORD}

Speaker: John Karns, Westinghouse Hanford Company

Documented by: Linda Mihalik, CH2M HILL

Date of Conversation: December 12, 1993

Mr. Karns addressed the issue of aerosol generated during high-pressure washing activities. He stated that hydroscrubbing of contaminated surfaces had been performed frequently in the past in the 100 Areas. Operators were located 10 to 20 feet from the spray surface, and the air in the vicinity of the operators was monitored routinely by Health Physics Technicians.

According to $\mathrm{Mr}$. Karns, the only facial protection worn by the operators was a spiash shield. Airborne contaminant levels at that distance were below levels at which respiratory protection was required. 
DOE/RL-94-15, Rev. 0

This page intentionally left blank. 
DOE/RL-94-15, Rev. 0

\section{APPENDIX B}

THERMAL EVALUATION OF PLASMA TORCH CUTTING 
DOE/RL-94-15, Rev. 0

This page intentionally left blank. 


\section{APPENDIX B}

THERMAL EVALUATION OF PLASMA TORCH CUTTING

A plasma torch generates temperatures of 11,093 to 27,760 degrees celsius in the ionized gas that is used for cutting (McGough and Knetl 1990). This temperature range is well above the boiling point of the radionuclides in the basin. For example, the boiling point of pure cesium is 678 degrees celsius; the oxide decomposes to the pure substance at 650 degrees celsius (CRC Press 1980). The bolling points for the pure substances and compounds of americium, cobalt, manganese, and plutonium, and strontium are higher, but still below the cutting temperatures.

The high cutting temperatures raise the following three questions:

- Can radionuclide gases be dispersed to the basin air space?

- To what extent could cutting increase evaporation of the basin water?

- What quantity of water could be heated to 100 degrees celsius or greater (required for 40 CFR 61 Appendix D calculations)?

The following information was obtained during actual operation of a torch on the Lower Core Support Assembly at Three Mile Island (McGough and Knet1 1990):

The materiais being cut were 1 to 2.5 inches thick, and cutting was performed under 35 feet of water. Material that was 2 inches thick or more required 180 volts and resulted in a torch travel speed of 7 to 8 inches per minute. Material less than 2 inches thick required a voltage of 140 volts and resulted in a torch travel speed of 12 inches per minute. The cutting current ranged from 450 to 860 amperes.

Combining the upper-bound voltage and amperage, the total power consumed by the torch is:

$180 V \times 860$ amps $=154,800$ watts

As indicated by the travel speeds, plasma torch cutting proceeds rapidly. Assuming that the torch is operated in the basin continuousiy for 8 hours, the total energy consumption during that time would be:

$$
\begin{aligned}
154,800 \text { watts } & \times 1 \mathrm{Joule} / \mathrm{sec} / \mathrm{watt} \times 8 \mathrm{~h} \times 60 \mathrm{~min} / \mathrm{hr} \\
& \times 60 \mathrm{sec} / \mathrm{min}=4.5 \times 10^{9} \mathrm{Joule}
\end{aligned}
$$

This energy dissipates by several mechanisms: the temperature of the metal and surrounding water increase, water, and other constituents (including radionuclides) vaporize, and water dissociates into hydrogen and oxygen gases. 
If all of this energy could be isolated and directed into uniformly heating the surrounding water to 100 degrees celsius, the maximum quantity of water heated would be:

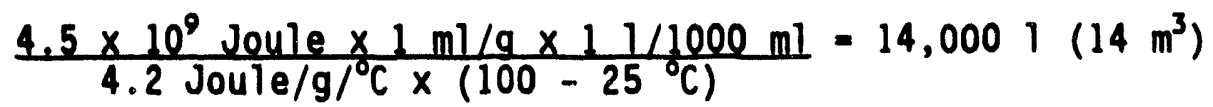

Initial temperature: $25^{\circ} \mathrm{C}\left(77^{\circ} \mathrm{F}\right)$

Heat capacity of water: $4.2 \mathrm{Joule} / \mathrm{g} /{ }^{\circ} \mathrm{C}$ (CRC Press 1980)

A volume of 14 cubic meters would be the equivalent of a sphere having a radius of approximately 1.5 meters ( 5 feet). Thus, in this worst-case scenario temperatures of 100 degrees celsius would be achieved in 14,000 liters of water and at a distance of up to 5 feet from the cutting point. This assumes an ideal system where the heat energy is uniformly distributed in the water and no energy dissipates by other mechanisms. In reality, the heat energy could not be "confined" in a volume around the torch, a temperature gradient would be established (temperatures near the cutting point would be higher than 100 degrees celsius and temperatures at a distance of 5 feet would be lower), and some of the energy would dissipate by other mechanisms.

If all of the energy were used to vaporize water, the maximum quantity of water evaporated would be:

$\frac{4.5 \times 10^{\circ} \text { Joule } \times 18 \mathrm{~g} / \mathrm{mol} \times 1 \mathrm{ml} / \mathrm{g} \times 1 / 1000 \mathrm{ml}}{4.1 \mathrm{E}+04 \mathrm{Jou} 1 \mathrm{e} / \mathrm{mol}+76 \mathrm{Joule} / \mathrm{mol} /{ }^{\circ} \mathrm{C} *\left(100^{\circ} \mathrm{C}-25^{\circ} \mathrm{C}\right)}=1,7001$
Initial temperature: $25{ }^{\circ} \mathrm{C}$
Heat capacity of water: $4.2 \mathrm{Joule} / \mathrm{g} /{ }^{\circ} \mathrm{C}\left(76 \mathrm{Joule} / \mathrm{mol} /{ }^{\circ} \mathrm{C}\right)$
Heat of vaporization (at $\left.100^{\circ} \mathrm{C}\right): 4.1 \mathrm{E}+04 \mathrm{Joule} / \mathrm{mol}$
(CRC Press 1980)

Again, this is a worst-case scenario. In reality, some of the heat energy would dissipate by other mechanisms.

Finally, although cutting temperatures suggest that gaseous radionuclides can be generated at the point of cutting, the evaluation of water temperatures indicates that the gaseous species cannot be sustained as the gases transfer away from the torch. The radionuclides only exist as the gaseous species so long as they remain at the elevated temperatures. However, as soon as the gases move away from the torch, they contact much cooler water. A temperature differential of several hundred degrees exists between small gas bubbles and the cooler surrounding water for no more than a few seconds. As demonstrated previously, temperatures in the surrounding water will be less than 100 degrees celstus at distances of only 5 feet from the torch. Thus, radionuclides vaporized at the cutting surface will recondense before they can contribute as gases to the source term above the water. However, the condensed particulate from the radionuclides continues to be a potential source term contributor. 
DOE/RL-94-15, Rev. 0

\section{REFERENCES}

CRC Press, 1980-81, Handbook of Chemistry and Physics, 61st Edition.

McGough, M. S., and G. J. Knet1/PCI Energy Services, 1990, "Underwater Plasma Cutting of the Lower Core Assembly and Metallurgical Sample of the Bottom head at Three Mile Island Unit 2," Excellent and Economic Nuclear Plan Performance, NE-Vol. 4, Book No. 100305. 
DOE/RL-94-15, Rev. 0

This page intentionally left blank. 
DOE/RL-94-15, Rev. 0

APPENDIX C

CAP-88 RESULTS 105N BASIN STABILIZATION

APP C-1 
DOE/RL-94-15, Rev. 0

This page intentionally left blank.

APP C-11 
January 19,1994

\section{To: Linda Mihalik}

\section{From: Paul D. Rittmann}

Westinghouse Hanford Company HO-36

376-8715 FAX: $376-1293$

Number of pages attached to this cover: 9

The attached CAP88PC run uses wind data from 1983 to 1991 (9 years) at an elevation of 89 meters. This is appropriate for a 200 foot stack release.

The receptor location from the CAP88PC output is $14.7 \mathrm{~km}$ east of $100 \mathrm{~N}$ Area. This is still onsite. The location is fictitious. It had to be entered this way because CAP88PC always picks the wrong wind transport direction. The actual worst case location is $11.5 \mathrm{~km}$ west of $100 \mathrm{~N}$ Area.

The dose factors you need are listed on page 2 of the SUMMARY. I marked the nuclide chains on that page. The doses in a chain need to be added together. For example, the dose factor for $5 r-90$ is really the sum of $3.85 \mathrm{E}-02$ and $7.17 \mathrm{E}-05 \mathrm{mrem}$, or $3.86 \mathrm{E}-02 \mathrm{mrem}$ per curie released over one year.

I will send all of the CAP88PC output attached to a cCMail message. 


$$
\begin{gathered}
\text { CA P 8 } 8-P C \\
\text { Version } 1.00 \\
\text { Clean Air Act Assessment Package - } 1988
\end{gathered}
$$

\title{
DOSE AND RISK EQUIVALENT SUMMA-RIES Non-Radon Individual Assessment Jan 19, 1994 10:27 am
}
Facility: 100 Area - $200 \mathrm{ft}$ Stack - Individual Nuclides Address: Westinghouse Hanford Company P.0. Box 1970
City: Richland
State: WA Zip: 99352-1970

\section{Source Category: \\ Source Type: Stack Emission Year: 1994}

\section{Comments: $14.7 \mathrm{~km} \mathrm{E}$ is equivalent to $11.5 \mathrm{~km} \mathrm{~W}$} Wind data generated at $100 \mathrm{~N}$ from 1983 to 1991

\author{
Dataset Name: $100 \mathrm{~N}$ for Linda \\ Dataset Date: Jan 19, 1994 10:27 am \\ Wind File: WNDFILES \JF10089.WND
}


ORGAN DOSE EQUIVALENT SUMMARY

(RN-222 Working Level Calculations Excluded)

\begin{tabular}{lc} 
Organ & $\begin{array}{c}\text { Selected } \\
\text { Individual } \\
\text { (mrem/y) }\end{array}$ \\
\hline GONADS & $2.55 E+00$ \\
BREAST & $9.82 E-01$ \\
R MAR & $1.44 E+01$ \\
LUNGS & $4.97 E+01$ \\
THYROID & $9.87 E-01$ \\
ENDOST & $1.71 E+02$ \\
RMNDR & $8.00 E+00$ \\
EFFEC & $1.60 E+01$
\end{tabular}

Radon Decay Product Concentration (working level)

$0.00 E+00$

PATHWAY EFFECTIVE DOSE EQUIVALENT SUMMARY (RN-222 Working Level Calculations Excluded)

\begin{tabular}{lc} 
Pathway & $\begin{array}{c}\text { Selected } \\
\text { Individual } \\
\text { (mrem/y) }\end{array}$ \\
\hline INGESTION & $1.94 E+00$ \\
INHALATION & $1.35 E+01$ \\
AIR IMMERSION & $2.64 E-05$ \\
GROUND SURFACE & $5.77 E-01$ \\
INTERNAL & $1.55 E+01$ \\
EXTERNAL & $5.77 E-01$ \\
TOTAL & $1.60 E+01$
\end{tabular}

Radon Decay Product Concentration (working level)

$0.00 E+00$ 
NUCLIDE EFFECTIVE DOSE EQUIVALENT SUMMARY (RN-222 Working Level Calculations Excluded)

Nuclide

Selected

Individual

$(\mathrm{mrem} / \mathrm{y})$

AM-241

CE -144

$[P R-144$

CO-60

CS -134

CS -137

BA-137M

$\mathrm{H}-3$

$K-40$

MN -54

PU -238

PU-239

PU-241

RU-106

RH-106

SB-125

TE-125M

SR-90

$Y-90$

U-235

TH-23]

$U-238$

TH-234

PA-234

U-234

TH-230

RA-226

$\mathrm{RN}-2 ? ?$

PO-218

PB-214

BI -214

PO-214

PB-210

BI -210

PO-210

4.25E+00

4.27E-03

1. $53 \mathrm{E}-07$

5.71E-02

$3.14 E-02$

1. $37 \mathrm{E}-02$

4. 59E-02

6. $98 E-06$

4. 53E-02

3. $65 \mathrm{E}-03$

2. $58 \mathrm{E}+00$

2. $78 \mathrm{E}+00$

4.39E-02

5.57E-03

5.65E-29

5.78E-03

9. $12 \mathrm{E}-05$

3. 85E-02

7.17E-05

9. $93 \mathrm{E}-01$

7.21E-06

9.29E-01

7.27E-04

2.14E-01

$1.04 E+00$

1. $86 \mathrm{E}+00$

$1.68 \mathrm{E}-01$

$0.00 E+00$

$0.00 E+00$

$3.08 \mathrm{E}-02$

$1.63 \mathrm{E}-01$

$0.00 E+00$

5.30E-01

$1.44 \mathrm{E}-03$

1. $84 \mathrm{E}-01$

TOTAL

$1.60 E+01$

Radon Decay Product Concentration (working level)

$0.00 E+00$ 
Jan 19, 1994 10:27 am

SUMMARY

Page 3

CANCER RISK SUMMARY

\begin{tabular}{lc} 
Cancer & $\begin{array}{c}\text { Selected Individual } \\
\text { Total Lifetime } \\
\text { Fatal Cancer Risk }\end{array}$ \\
\hline LEUKEMIA & $1.40 E-05$ \\
BONE & $7.67 E-06$ \\
THYROID & $3.58 E-07$ \\
BREAST & $3.02 E-06$ \\
LUNG & $8.46 E-05$ \\
STOMACH & $1.92 E-06$ \\
BOWEL & $1.06 E-06$ \\
LIVER & $2.41 E-05$ \\
PANCREAS & $1.32 E-06$ \\
URINARY & $2.19 E-06$ \\
OTHER & $1.62 E-06$ \\
TOTAL & $1.42 E-04$ \\
& \\
& Selected Individual \\
Cancer Risk
\end{tabular}




\section{PATHWAY RISK SUMMARY}

\begin{tabular}{lc} 
Pathway & $\begin{array}{c}\text { Selected Individual } \\
\text { Total Lifetime } \\
\text { Fatal Cancer Risk }\end{array}$ \\
\cline { 2 - 3 } $\begin{array}{lc}\text { INGESTION } & 1.22 E-05 \\
\text { INHALATION } & 1.16 E-04 \\
\text { AIR IMMERSION } & 6.34 E-10 \\
\text { GROUND SURFACE } & 1.38 E-05 \\
\text { INTERNAL } & 1.28 E-04 \\
\text { EXTERNAL } & 1.38 E-05 \\
\text { TOTAL } & 1.42 E-04 \\
& \\
& \text { Selected Individual } \\
\text { Cancer Risk }\end{array}$ \\
\cline { 2 - 2 } Radon Decay Product \\
Lung Exposure & $0.00 E+00$ \\
Total Fatal Risk & \\
A11 Exposures & $1.42 E-04$
\end{tabular}


NUCLIDE RISK SUMMARY

Nucl ide

AM-241

CE-144

PR-144

CO-60

CS- 134

CS -137

$B A-137 M$

$\mathrm{H}-3$

$\mathrm{K}-40$

$\mathrm{MN}-54$

PU-238

PU-239

PU-241

RU-106

RH-106

SB-125

$T E-125 \mathrm{M}$

SR-90

$Y-90$

$U-235$

$\mathrm{TH}-231$

$\mathrm{U}-238$

TH-234

PA-234

$U-234$

TH-230

RA-226

$\mathrm{RN}-222$

PO- 218

PB-214

BI -214

$\mathrm{PO}-214$

PB-210

BI -210

$\mathrm{P} 0-210$

TOTAL
Selected Individual Total Lifetime Fatal Cancer Risk

2.17E-05

$1.84 E-07$

4. $30 E-12$

1. $43 \mathrm{E}-06$

$7.96 \mathrm{E}-07$

$3.58 \mathrm{E}-07$

$1.10 E-06$

$1.89 \mathrm{E}-10$

$1.14 \mathrm{E}-06$

$8.76 E-08$

$2.17 E-05$

2. $15 \mathrm{E}-05$

$1.67 \mathrm{E}-07$

2. $40 \mathrm{E}-07$

1. $36 \mathrm{E}-33$

1. $38 \mathrm{E}-07$

1. $57 \mathrm{E}-09$

6. $47 \mathrm{E}-07$

2. $43 \mathrm{E}-09$

1. $29 \mathrm{E}-05$

2. $10 \mathrm{E}-10$

1. $19 E-05$

2. $04 E-08$

5. $12 \mathrm{E}-06$

1.32E-05

1. $52 \mathrm{E}-05$

1. $98 \mathrm{E}-06$

$0.00 E+00$

$0.00 E+00$

7.28E-07

3. $94 \mathrm{E}-06$

$0.00 E+00$

3. $78 \mathrm{E}-06$

$3.84 E-08$

$1.86 \mathrm{E}-06$

$1.42 E-04$ 
Selected Individual

Cancer Risk

Radon Decay Product

Lung Exposure

$0.00 E+00$

Total Fatal Risk

All Exposures

1. $42 E-04$

Jan 19, $1994 \quad 10: 27$ am

SUMMARY

Page 6

INDIVIDUAL EFFECTIVE DOSE EQUIVALENT RATE (mrem/y)

(A11 Radionuclides and Pathways)

Distance (m)

\section{Direction 14700}

$\begin{array}{rl}N & 6.9 E+00 \\ \text { NNW } & 5.6 E+00 \\ \text { NW } & 7.5 E+00 \\ \text { WNW } & 8.8 E+00 \\ W & 1.2 E+01 \\ \text { WSW } & 6.0 E+00 \\ \text { SW } & 5.3 E+00 \\ \text { SSW } & 5.5 E+00 \\ S & 8.3 E+00 \\ \text { SSE } & 6.6 E+00 \\ \text { SE } & 7.8 E+00 \\ \text { ESE } & 1.0 E+01 \\ E & 1.6 E+01 \\ \text { ENE } & 1.0 E+01 \\ \text { NE } & 7.4 E+00 \\ \text { NNE } & 5.3 E+00\end{array}$




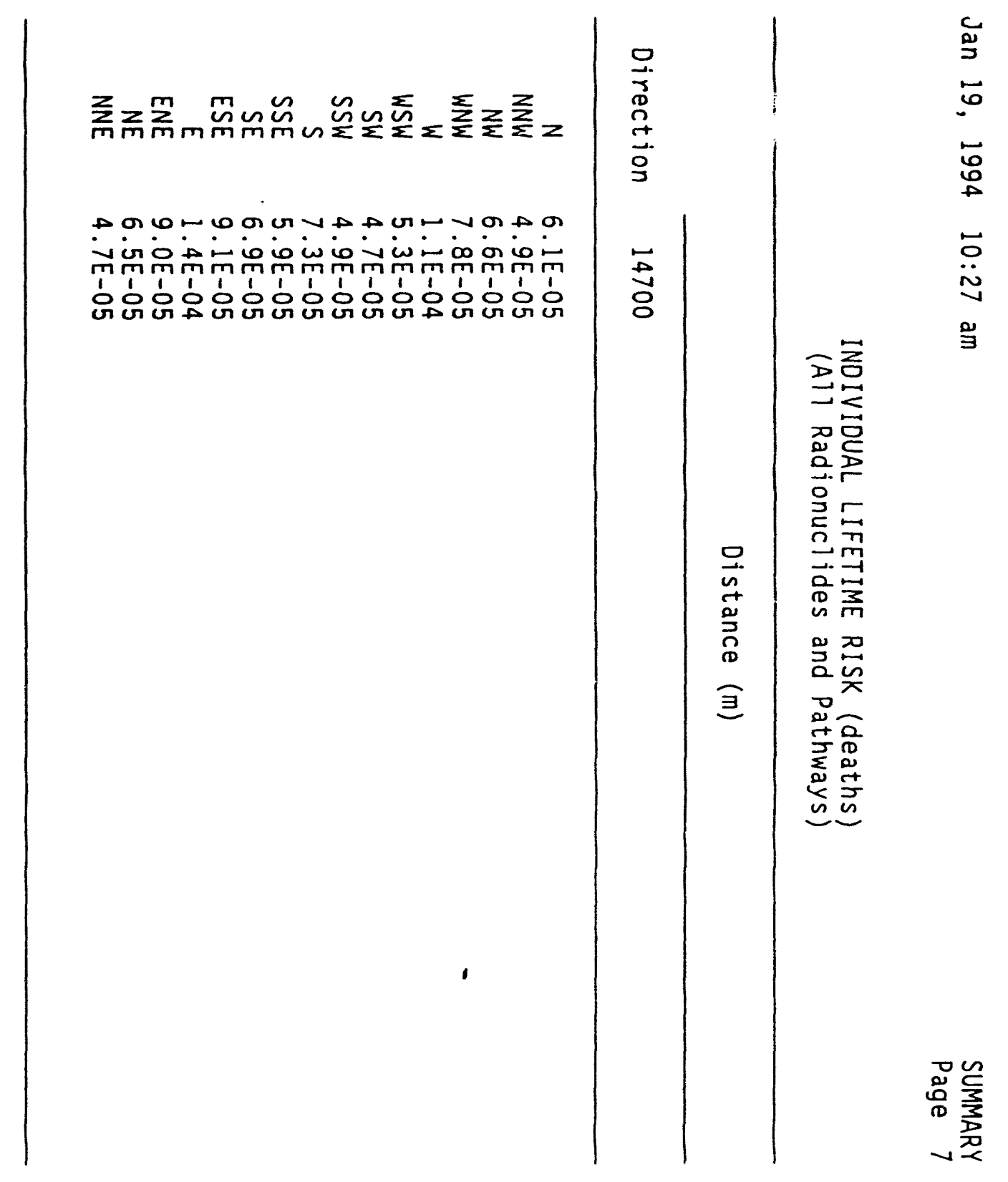




$$
\begin{gathered}
C A \cap 88-P C \\
\text { Version } 1.00 \\
\text { Clean Air Act Assessment Package - } 1988
\end{gathered}
$$

\section{SYNOPSIS REPORT}

Non-Radon Individual Assessment Jan 19, 1994 10:27 am

\footnotetext{
Facility: 100 Area - $200 \mathrm{ft}$ Stack - Individual Nuclides Address: Westinghouse Hanford Company P.0. Box 1970

City: Richland

State: WA Zip: 99352-1970
}

$$
\frac{\begin{array}{c}
\text { Effective Dose Equivalent } \\
\text { (mrem/year) }
\end{array}}{1.60 E+01}
$$

At This Location: 14700 Meters East

Source Category:

Source Type: Stack

Emission Year: 1994

Comments: $14.7 \mathrm{~km} \cdot \mathrm{E}$ is equivalent to $11.5 \mathrm{~km} \mathrm{~W}$ Wind data generated at $100 \mathrm{~N}$ from 1983 to 1991

Dataset Name: $100 \mathrm{~N}$ for Linda

Dataset Date: Jan 19, 1994 10:27 am

Wind File: WNDFILES\JF10089. WND 
MAXIMALLY EXPOSED INDIVIDUAL

(RN-222 Working Level Calculations Excluded)

Location of The Individual: 14700 Meters East

Lifetime Fatal Cancer Risk: 1.42E-04

ORGAN DOSE EQUIVALENT SUMMARY

(RN-222 Working Level Calculations Excluded)

\begin{tabular}{ll} 
Organ & $\begin{array}{c}\text { Equivalent } \\
\text { (mrem/y) }\end{array}$ \\
\cline { 2 - 2 } GONADS & $2.55 E+00$ \\
BREAST & $9.82 E-01$ \\
R MAR & $1.44 E+01$ \\
LUNGS & $4.97 E+01$ \\
THYROID & $9.87 E-01$ \\
ENDOST & $1.71 E+02$ \\
RMNDR & $8.00 E+00$ \\
EFFEC & $1.60 E+01$
\end{tabular}


RADIONUCLIDE EMISSIONS DURING THE YEAR 1994

\begin{tabular}{|c|c|c|c|c|}
\hline Nucl ide & Class & Size & $\begin{array}{c}\text { Source } \\
\# 1 \\
C i / y\end{array}$ & $\begin{array}{l}\text { TOTAL } \\
\mathrm{Ci} / \mathrm{y}\end{array}$ \\
\hline $\begin{array}{l}A M-241 \\
C E-144 \\
P R-144 \\
C O-60 \\
C S-134 \\
C S-137 \\
B A-137 M \\
H-3 \\
K-40 \\
M N-54 \\
P U-238 \\
P U-239 \\
P U-241 \\
R U-106 \\
R H-106 \\
S B-125 \\
T E-125 M \\
S R-90 \\
Y-90 \\
U-235 \\
T H-231 \\
U-238 \\
T H-234 \\
P A-234 \\
U-234 \\
T H-230 \\
R A-226 \\
R N-222 \\
P O-218 \\
P B-214 \\
B I-214 \\
P O-214 \\
P B-210 \\
B I-210 \\
P O-210\end{array}$ & $\begin{array}{l}W \\
Y \\
Y \\
Y \\
D \\
D \\
D \\
* \\
D \\
W \\
Y \\
Y \\
Y \\
Y \\
Y \\
W \\
W \\
D \\
Y \\
Y \\
Y \\
Y \\
Y \\
Y \\
Y \\
Y \\
W \\
* \\
W \\
D \\
W \\
W \\
D \\
W \\
W\end{array}$ & $\begin{array}{l}1.00 \\
1.00 \\
1.00 \\
1.00 \\
1.00 \\
1.00 \\
1.00 \\
0.00 \\
1.00 \\
1.00 \\
1.00 \\
1.00 \\
1.00 \\
1.00 \\
1.00 \\
1.00 \\
1.00 \\
1.00 \\
1.00 \\
1.00 \\
1.00 \\
1.00 \\
1.00 \\
1.00 \\
1.00 \\
1.00 \\
1.00 \\
0.00 \\
1.00 \\
1.00 \\
1.00 \\
1.00 \\
1.00 \\
1.00 \\
1.00\end{array}$ & $\begin{array}{l}1.0 E+00 \\
1.0 E+00 \\
1.0 E+00 \\
1.0 E+00 \\
1.0 E+00 \\
1.0 E+00 \\
9.5 E-01 \\
1.0 E+00 \\
1.0 E+00 \\
1.0 E+00 \\
1.0 E+00 \\
1.0 E+00 \\
1.0 E+00 \\
1.0 E+00 \\
1.0 E+00 \\
1.0 E+00 \\
2.5 E-01 \\
1.0 E+00 \\
1.0 E+00 \\
1.0 E+00 \\
1.0 E+00 \\
1.0 E+00 \\
1.0 E+00 \\
1.6 E-03 \\
1.0 E+00 \\
1.0 E+00 \\
1.0 E+00 \\
0.0 E+00 \\
0.0 E+00 \\
0.0 E+00 \\
0.0 E+00 \\
0.0 E+00 \\
1.0 E+00 \\
1.0 E+00 \\
1.0 E+00\end{array}$ & $\begin{array}{l}1.0 E+00 \\
1.0 E+00 \\
1.0 E+00 \\
1.0 E+00 \\
1.0 E+00 \\
1.0 E+00 \\
9.5 E-01 \\
1.0 E+00 \\
1.0 E+00 \\
1.0 E+00 \\
1.0 E+00 \\
1.0 E+00 \\
1.0 E+00 \\
1.0 E+00 \\
1.0 E+00 \\
1.0 E+00 \\
2.5 E-01 \\
1.0 E+00 \\
1.0 E+00 \\
1.0 E+00 \\
1.0 E+00 \\
1.0 E+00 \\
1.0 E+00 \\
1.6 E-03 \\
1.0 E+00 \\
1.0 E+00 \\
1.0 E+00 \\
0.0 E+00 \\
0.0 E+00 \\
0.0 E+00 \\
0.0 E+00 \\
0.0 E+00 \\
1.0 E+00 \\
1.0 E+00 \\
1.0 E+00\end{array}$ \\
\hline
\end{tabular}

\section{SITE INFORMATION}

Temperature: 12 degrees $C$ Precipitation: $\quad 16 \mathrm{~cm} / \mathrm{y}$

Mixing Height: $1000 \mathrm{~m}$ 
SOURCE INFORMATION

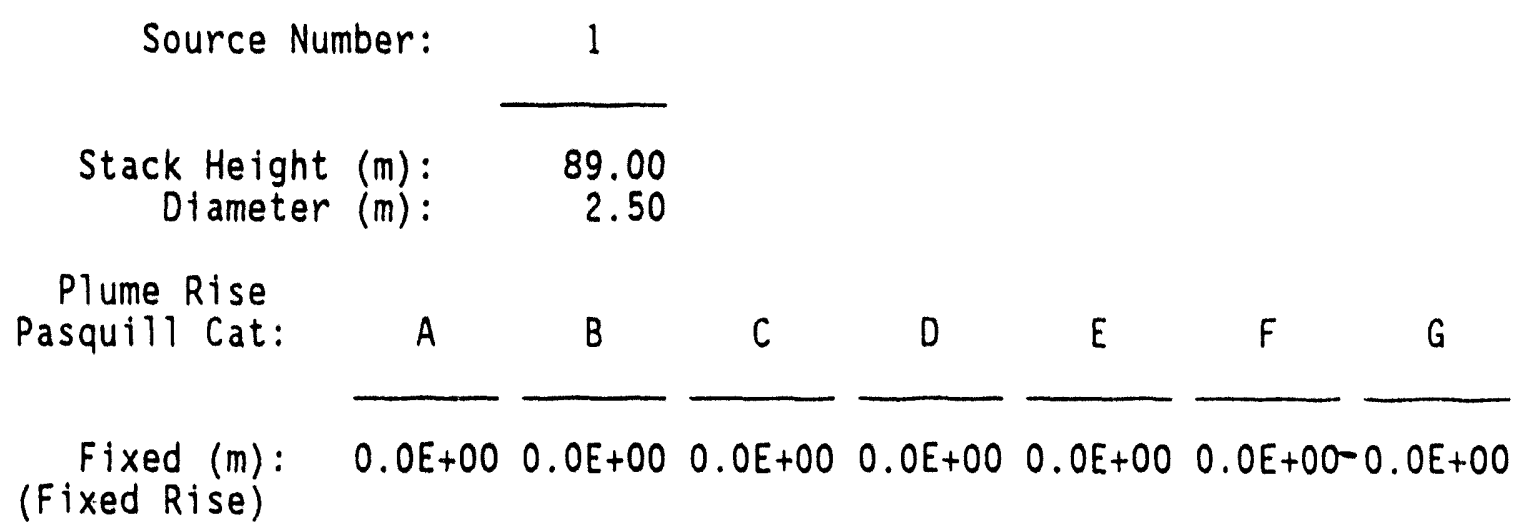

AGRICULTURAL DATA

\begin{tabular}{|c|c|c|c|}
\hline & Vegetable & Milk & Meat \\
\hline $\begin{array}{l}\text { Fraction Home Produced: } \\
\text { Fraction From Assessment Area: } \\
\text { Fraction Imported: }\end{array}$ & $\begin{array}{l}1.000 \\
0.000 \\
0.000\end{array}$ & $\begin{array}{l}1.000 \\
0.000 \\
0.000\end{array}$ & $\begin{array}{l}1.000 \\
0.000 \\
0.000\end{array}$ \\
\hline
\end{tabular}

Food Arrays were not gerierated for this run. Default Values used.

DISTANCES USED FOR MAXIMUM INDIVIDUAL ASSESSMENT 


$$
\begin{gathered}
\text { CA P 8 } 8-P C \\
\text { Version } 1.00 \\
\text { Clean Air Act Assessment Package - } 1988
\end{gathered}
$$

\author{
WEATHER DATA \\ Non-Radon Individual Assessment \\ Jan 19, 1994 10:27 am
}

\author{
Facility: 100 Area - $200 \mathrm{ft}$ Stack - Individual Nuclides \\ Address: Westinghouse Hanford Company \\ P.0. Box 1970 \\ City: Richland \\ State: WA Zip: $99352-1970$
Source Category:
Source Type: Stack
Emission Year: 1994 \\ Comments: $14.7 \mathrm{~km} \mathrm{E}$ is equivalent to $11.5 \mathrm{~km} \mathrm{~W}$ \\ Wind data generated at $100 \mathrm{~N}$ from 1983 to 1991 \\ Dataset Name: 100N for Linda \\ Dataset Date: Jan 19, 1994 10:27 am \\ Wind File: WNDFILES IJF10089.WND
}


Jan 19, 1994 10:27 am

WEATHER

Page 1

HARMONIC AVERAGE WIND SPEEDS (WIND TOWARDS)

\begin{tabular}{|c|c|c|c|c|c|c|c|c|}
\hline \multirow[b]{2}{*}{ Dir } & \multicolumn{7}{|c|}{ Pasquill Stability Class } & \multirow{2}{*}{$\begin{array}{l}\text { Wind } \\
\text { Frequency }\end{array}$} \\
\hline & A & B & C & $D$ & $E$ & $F$ & $G$ & \\
\hline $\begin{array}{r}N \\
N N W \\
N W \\
W N W \\
W \\
W S W \\
S W \\
S S W \\
S \\
S S E \\
S E \\
E S E \\
E \\
E N E \\
N E \\
N N E\end{array}$ & $\begin{array}{l}1.681 \\
1.968 \\
2.199 \\
1.743 \\
1.653 \\
1.628 \\
2.397 \\
2.757 \\
1.956 \\
1.752 \\
2.159 \\
2.703 \\
2.605 \\
2.612 \\
2.947 \\
2.204\end{array}$ & $\begin{array}{l}1.778 \\
1.531 \\
1.558 \\
1.586 \\
1.561 \\
1.611 \\
2.113 \\
2.744 \\
1.904 \\
1.576 \\
1.960 \\
2.430 \\
2.417 \\
2.309 \\
2.303 \\
1.720\end{array}$ & $\begin{array}{l}1.424 \\
1.795 \\
1.683 \\
1.520 \\
1.581 \\
1.430 \\
1.931 \\
2.372 \\
1.642 \\
1.448 \\
1.827 \\
2.307 \\
2.292 \\
1.957 \\
2.360 \\
1.625\end{array}$ & $\begin{array}{l}1.547 \\
1.713 \\
1.770 \\
1.605 \\
1.474 \\
1.637 \\
2.033 \\
2.301 \\
1.873 \\
1.698 \\
2.129 \\
3.002 \\
2.912 \\
2.644 \\
2.348 \\
2.087\end{array}$ & $\begin{array}{l}1.767 \\
1.845 \\
2.091 \\
1.941 \\
1.730 \\
1.865 \\
2.088 \\
2.378 \\
2.104 \\
1.772 \\
2.310 \\
3.525 \\
3.890 \\
3.097 \\
2.426 \\
2.003\end{array}$ & $\begin{array}{l}1.458 \\
1.645 \\
1.660 \\
1.756 \\
1.785 \\
1.683 \\
1.621 \\
1.917 \\
1.670 \\
1.548 \\
1.586 \\
1.811 \\
2.171 \\
2.128 \\
1.669 \\
1.475\end{array}$ & $\begin{array}{l}1.262 \\
1.353 \\
1.389 \\
1.504 \\
1.574 \\
1.539 \\
1.320 \\
1.326 \\
1.364 \\
1.162 \\
1.244 \\
1.351 \\
1.615 \\
1.705 \\
1.476 \\
1.433\end{array}$ & $\begin{array}{l}0.038 \\
0.033 \\
0.048 \\
0.054 \\
0.073 \\
0.039 \\
0.040 \\
0.049 \\
0.060 \\
0.045 \\
0.062 \\
0.104 \\
0.166 \\
0.094 \\
0.060 \\
0.035\end{array}$ \\
\hline
\end{tabular}

ARITHMETIC AVERAGE WIND SPEEDS (WIND TOWARDS)

Pasquill Stability Class

\begin{tabular}{rccccccc}
\cline { 2 - 7 } Dir & $A$ & $B$ & $C$ & $D$ & $E$ & $F$ & $G$ \\
\hline N & 3.055 & 4.038 & 2.806 & 3.127 & 3.657 & 2.710 & 2.001 \\
NNW & 3.197 & 2.857 & 3.302 & 3.315 & 3.810 & 2.914 & 2.224 \\
NW & 3.496 & 2.507 & 2.786 & 3.216 & 3.940 & 3.263 & 2.214 \\
WNW & 2.701 & 2.634 & 2.360 & 2.631 & 3.295 & 3.092 & 2.887 \\
W & 2.501 & 2.438 & 2.485 & 2.329 & 3.051 & 3.349 & 2.745 \\
WSW & 2.826 & 2.635 & 2.184 & 2.886 & 3.556 & 3.407 & 2.812 \\
SW & 4.081 & 4.060 & 3.535 & 3.917 & 4.984 & 3.311 & 2.033 \\
SSW & 4.798 & 5.882 & 5.439 & 5.408 & 6.371 & 5.504 & 2.492 \\
S & 3.393 & 4.088 & 3.766 & 4.096 & 5.307 & 3.608 & 2.699 \\
SSE & 2.734 & 2.531 & 2.241 & 3.279 & 3.882 & 3.090 & 1.773 \\
SE & 4.842 & 4.313 & 4.417 & 5.177 & 5.585 & 3.079 & 1.929 \\
ESE & 5.637 & 5.804 & 5.862 & 6.890 & 7.308 & 3.667 & 2.278 \\
E & 4.670 & 4.738 & 4.425 & 5.814 & 6.756 & 4.291 & 2.844 \\
ENE & 4.737 & 4.655 & 4.270 & 5.069 & 5.679 & 4.300 & 3.064 \\
NE & 5.452 & 5.401 & 5.543 & 5.575 & 5.305 & 3.159 & 2.555 \\
NNE & 4.244 & 3.531 & 4.136 & 5.411 & 4.776 & 2.743 & 2.319
\end{tabular}


FREQUENCIES OF STABILITY CLASSES (WIND TOWARDS)

\begin{tabular}{|c|c|c|c|c|c|c|c|}
\hline \multirow[b]{2}{*}{ Dir } & \multicolumn{6}{|c|}{ Pasquill Stability Class } & \multirow[b]{2}{*}{$G$} \\
\hline & $A$ & $B$ & $C$ & $D$ & $E$ & $F$ & \\
\hline $\begin{array}{r}N \\
N N W \\
N W \\
W N W \\
W \\
W S W \\
S W \\
S S W \\
S \\
S S E \\
S E \\
E S E \\
E \\
E N E \\
N E \\
N N E\end{array}$ & $\begin{array}{l}0.1082 \\
0.1064 \\
0.1151 \\
0.1065 \\
0.0941 \\
0.0876 \\
0.1796 \\
0.2037 \\
0.2020 \\
0.1955 \\
0.2006 \\
0.1675 \\
0.1210 \\
0.1223 \\
0.1581 \\
0.1203\end{array}$ & $\begin{array}{l}0.0449 \\
0.0547 \\
0.0460 \\
0.0467 \\
0.0409 \\
0.0335 \\
0.0574 \\
0.0679 \\
0.0546 \\
0.0517 \\
0.0546 \\
0.0443 \\
0.0361 \\
0.0383 \\
0.0516 \\
0.0372\end{array}$ & $\begin{array}{l}0.0475 \\
0.0547 \\
0.0523 \\
0.0449 \\
0.0382 \\
0.0438 \\
0.0599 \\
0.0576 \\
0.0579 \\
0.0494 \\
0.0498 \\
0.0404 \\
0.0301 \\
0.0319 \\
0.0499 \\
0.0458\end{array}$ & $\begin{array}{l}0.3245 \\
0.3283 \\
0.3326 \\
0.3159 \\
0.2428 \\
0.2294 \\
0.2519 \\
0.2840 \\
0.2781 \\
0.2584 \\
0.2648 \\
0.2772 \\
0.2541 \\
0.2660 \\
0.3111 \\
0.3410\end{array}$ & $\begin{array}{l}0.2797 \\
0.2705 \\
0.2552 \\
0.2505 \\
0.2510 \\
0.2500 \\
0.2319 \\
0.2016 \\
0.2086 \\
0.1978 \\
0.2103 \\
0.2810 \\
0.3311 \\
0.2915 \\
0.2429 \\
0.2550\end{array}$ & $\begin{array}{l}0.1372 \\
0.1337 \\
0.1485 \\
0.1701 \\
0.2360 \\
0.2429 \\
0.1546 \\
0.1337 \\
0.1457 \\
0.1708 \\
0.1509 \\
0.1299 \\
0.1481 \\
0.1734 \\
0.1248 \\
0.1404\end{array}$ & $\begin{array}{l}0.0580 \\
0.0517 \\
0.0502 \\
0.0654 \\
0.0969 \\
0.1134 \\
0.0648 \\
0.0514 \\
0.0530 \\
0.0764 \\
0.0690 \\
0.0597 \\
0.0795 \\
0.0766 \\
0.0616 \\
0.0602\end{array}$ \\
\hline TOT & 0.1424 & 0.0457 & 0.0438 & 0.2781 & 0.2621 & 0.1579 & 0.0698 \\
\hline
\end{tabular}

ADOITIONAL WEATHER INFORMATION

Average Air Temperature: 12.0 degrees $C$ $285.2 \mathrm{~K}$

Precipitation: $\quad 16.0 \mathrm{~cm} / \mathrm{y}$ Lid Height: 1000 meters Surface Roughness Length: 0.010 meters Height of Wind Measurements: 10.0 meters Average Wind Speed: $4.401 \mathrm{~m} / \mathrm{s}$

Vertical Temperature Gradients:
STABILITY E
STABILITY F
$0.073 \mathrm{k} / \mathrm{m}$
STABILITY G
$0.109 \mathrm{k} / \mathrm{m}$
$0.146 \mathrm{k} / \mathrm{m}$ 


\author{
C A P $88-P C$ \\ Version 1.00 \\ Clean Air Act Assessment Package - 1988
}

\author{
GENERAL DATA \\ Non-Radon Individual Assessment \\ Jan 19, 1994 10:27 am
}

Facility: 100 Area - $200 \mathrm{ft}$ Stack - Individual Nuclides Address: Westinghouse Hanford Company

City: Richland

State: $N A$

Zip: $99352-1970$

\title{
Source Category: \\ Source Type: Stack \\ Emission Year: 1994
}

Comments: $14.7 \mathrm{kmE}$ is equivalent to $11.5 \mathrm{~km} \mathrm{~W}$

Wind data generated at $100 \mathrm{~N}$ from 1983 to 1991

Dataset Name: 100N for Linda

Dataset Date: Jan 19, 1994 10:27 am

Wind File: WNDFILESIJF10089. WND 
VALUES FOR RADIONUCLIDE-DEPENDENT PARAMETERS

\begin{tabular}{|c|c|c|c|c|}
\hline Nuclide & $\begin{array}{c}\text { Clearance } \\
\text { Class }\end{array}$ & $\begin{array}{c}\text { Particle } \\
\text { Size } \\
\text { (microns) }\end{array}$ & $\begin{array}{l}\text { Scavenging } \\
\text { Coefficient } \\
\text { (per second) }\end{array}$ & $\begin{array}{l}\text { Dry } \\
\text { Deposition } \\
\text { Velocity } \\
(\mathrm{m} / \mathrm{s})\end{array}$ \\
\hline $\begin{array}{l}A M-241 \\
C E-144 \\
P R-144 \\
C O-60 \\
C S-134 \\
C S-137 \\
B A-137 M \\
H-3 \\
K-40 \\
M N-54 \\
P U-238 \\
P U-239 \\
P U-241 \\
R U-106 \\
R H-106 \\
S B-125 \\
T E-125 M \\
S R-90 \\
Y-90 \\
U-235 \\
T H-231 \\
U-238 \\
T H-234 \\
P A-234 \\
U-234 \\
T H-230 \\
R A-226 \\
R N-222 \\
P O-218 \\
P B-214 \\
B I-214 \\
P O-214 \\
P B-210 \\
B I-210 \\
P O-210\end{array}$ & $\begin{array}{l}W \\
Y \\
Y \\
Y \\
D \\
D \\
D \\
* \\
D \\
W \\
Y \\
Y \\
Y \\
Y \\
Y \\
W \\
W \\
D \\
Y \\
Y \\
Y \\
Y \\
Y \\
Y \\
Y \\
Y \\
W \\
* \\
W \\
D \\
W \\
W \\
D \\
W \\
W\end{array}$ & $\begin{array}{l}1.0 \\
1.0 \\
1.0 \\
1.0 \\
1.0 \\
1.0 \\
1.0 \\
0.0 \\
1.0 \\
1.0 \\
1.0 \\
1.0 \\
1.0 \\
1.0 \\
1.0 \\
1.0 \\
1.0 \\
1.0 \\
1.0 \\
1.0 \\
1.0 \\
1.0 \\
1.0 \\
1.0 \\
1.0 \\
1.0 \\
1.0 \\
0.0 \\
1.0 \\
1.0 \\
1.0 \\
1.0 \\
1.0 \\
1.0 \\
1.0\end{array}$ & $\begin{array}{l}1.60 E-06 \\
1.60 E-06 \\
1.60 E-06 \\
1.60 E-06 \\
1.60 E-06 \\
1.60 E-06 \\
1.60 E-06 \\
0.00 E+00 \\
1.60 E-06 \\
1.60 E-06 \\
1.60 E-06 \\
1.60 E-06 \\
1.60 E-06 \\
1.60 E-06 \\
1.60 E-06 \\
1.60 E-06 \\
1.60 E-06 \\
1.60 E-06 \\
1.60 E-06 \\
1.60 E-05 \\
1.60 E-06 \\
1.60 E-06 \\
1.60 E-06 \\
1.60 E-06 \\
1.60 E-06 \\
1.60 E-06 \\
1.60 E-06 \\
0.00 E+00 \\
1.60 E-06 \\
1.60 E-06 \\
1.60 E-06 \\
1.60 E-06 \\
1.60 E-06 \\
1.60 E-06 \\
1.60 E-06\end{array}$ & $\begin{array}{r}1.80 E-03 \\
1.80 E-03 \\
1.80 E-03 \\
1.80 E-03 \\
1.80 E-03 \\
-1.80 E-03 \\
1.80 E-03 \\
0.00 E+00 \\
1.80 E-03 \\
1.80 E-03 \\
1.80 E-03 \\
1.80 E-03 \\
1.80 E-03 \\
1.80 E-03 \\
1.80 E-03 \\
1.80 E-03 \\
1.80 E-03 \\
1.80 E-03 \\
1.80 E-03 \\
1.80 E-03 \\
1.80 E-03 \\
1.80 E-03 \\
1.80 E-03 \\
1.80 E-03 \\
1.80 E-03 \\
1.80 E-03 \\
1.80 E-03 \\
0.00 E+00 \\
1.80 E-03 \\
1.80 E-03 \\
1.80 E-03 \\
1.80 E-03 \\
1.80 E-03 \\
1.80 E-03 \\
1.80 E-03\end{array}$ \\
\hline
\end{tabular}




\begin{tabular}{|c|c|c|c|c|c|}
\hline \multirow[b]{2}{*}{ Nuclide } & \multicolumn{3}{|c|}{ DECAY CONSTANT (PER DAY) } & \multicolumn{2}{|c|}{ TRANSFER COEFFICIENT } \\
\hline & active (1) & Surface & Water & $\operatorname{Milk}(2)$ & Meat (3) \\
\hline $\begin{array}{l}A M-241 \\
C E-144 \\
P R-144 \\
C O-60 \\
C S-134 \\
C S-137 \\
B A-137 M \\
H-3 \\
K-40 \\
M N-54 \\
P U-238 \\
P U-239 \\
P U-241 \\
R U-106 \\
R H-106 \\
S B-125 \\
T E-125 M \\
\text { SR-90 } \\
Y-90 \\
U-235 \\
T H-231 \\
U-238 \\
T H-234 \\
P A-234 \\
U-234 \\
T H-230 \\
R A-226 \\
R N-222 \\
P O-218 \\
P B-214 \\
B I-214 \\
P O-214 \\
P B-210 \\
B I-210 \\
P O-210\end{array}$ & $\begin{array}{l}0.00 E+00 \\
0.00 E+00 \\
5.78 E+01 \\
0.00 E+00 \\
0.00 E+00 \\
0.00 E+00 \\
3.91 E+02 \\
0.00 E+00 \\
0.00 E+00 \\
0.00 E+00 \\
0.00 E+00 \\
0.00 E+00 \\
0.00 E+00 \\
0.00 E+00 \\
2.00 E+03 \\
0.00 E+00 \\
1.20 E-02 \\
0.00 E+00 \\
2.60 E-01 \\
0.00 E+00 \\
6.52 E-01 \\
0.00 E+00 \\
2.88 E-02 \\
2.48 E+00 \\
0.00 E+00 \\
0.00 E+00 \\
0.00 E+00 \\
1.81 E-01 \\
3.27 E+02 \\
3.72 E+01 \\
5.02 E+01 \\
3.66 E+08 \\
0.00 E+00 \\
1.38 E-01 \\
0.00 E+00\end{array}$ & $\begin{array}{l}5.48 E-05 \\
5.48 E-05 \\
5.48 E-05 \\
5.48 E-05 \\
5.48 E-05 \\
5.48 E-05 \\
5.48 E-05 \\
5.48 E-05 \\
5.48 E-05 \\
5.48 E-05 \\
5.48 E-05 \\
5.48 E-05 \\
5.48 E-05 \\
5.48 E-05 \\
5.48 E-05 \\
5.48 E-05 \\
5.48 E-05 \\
5.48 E-05 \\
5.48 E-05 \\
5.48 E-05 \\
5.48 E-05 \\
5.48 E-05 \\
5.48 E-05 \\
5.48 E-05 \\
5.48 E-05 \\
5.48 E-05 \\
5.48 E-05 \\
5.48 E-05 \\
5.48 E-05 \\
5.48 E-05 \\
5.48 E-05 \\
5.48 E-05 \\
5.48 E-05 \\
5.48 E-05 \\
5.48 E-05\end{array}$ & $\begin{array}{l}0.00 E+00 \\
0.00 E+00 \\
0.00 E+00 \\
0.00 E+00 \\
0.00 E+00 \\
0.00 E+00 \\
0.00 E+00 \\
0.00 E+00 \\
0.00 E+00 \\
0.00 E+00 \\
0.00 E+00 \\
0.00 E+00 \\
0.00 E+00 \\
0.00 E+00 \\
0.00 E+00 \\
0.00 E+00 \\
0.00 E+00 \\
0.00 E+00 \\
0.00 E+00 \\
0.00 E+00 \\
0.00 E+00 \\
0.00 E+00 \\
0.00 E+00 \\
0.00 E+00 \\
0.00 E+00 \\
0.00 E+00 \\
0.00 E+00 \\
0.00 E+00 \\
0.00 E+00 \\
0.00 E+00 \\
0.00 E+00 \\
0.00 E+00 \\
0.00 E+00 \\
0.00 E+00 \\
0.00 E+00\end{array}$ & $\begin{array}{l}4.00 E-07 \\
2.00 E-05 \\
2.00 E-05 \\
2.00 E-03 \\
7.00 E-03 \\
7.00 E-03 \\
3.50 E-04- \\
0.00 E+00 \\
7.00 E-03 \\
3.50 E-04 \\
1.00 E-07 \\
1.00 E-07 \\
1.00 E-07 \\
6.00 E-07 \\
1.00 E-02 \\
1.00 E-04 \\
2.00 E-04 \\
1.50 E-03 \\
2.00 E-05 \\
6.00 E-04 \\
5.00 E-06 \\
6.00 E-04 \\
5.00 E-06 \\
5.00 E-06 \\
6.00 E-04 \\
5.00 E-06 \\
4.50 E-04 \\
0.00 E+00 \\
3.50 E-04 \\
2.50 E-04 \\
5.00 E-04 \\
3.50 E-04 \\
2.50 E-04 \\
5.00 E-04 \\
3.50 E-04\end{array}$ & $\begin{array}{l}3.50 E-06 \\
7.50 E-04 \\
3.00 E-04 \\
2.00 E-02 \\
2.00 E-02 \\
2.00 E-02 \\
1.50 E-04 \\
0.00 E+00 \\
2.00 E-02 \\
4.00 E-04 \\
5.00 E-07 \\
5.00 E-07 \\
5.00 E-07 \\
2.00 E-03 \\
2.00 E-03 \\
1.00 E-03 \\
1.50 E-02 \\
3.00 E-04 \\
3.00 E-04 \\
2.00 E-04 \\
6.00 E-06 \\
2.00 E-04 \\
6.00 E-06 \\
1.00 E-05 \\
2.00 E-04 \\
6.00 E-06 \\
2.50 E-04 \\
0.00 E+00 \\
9.50 E-05 \\
3.00 E-04 \\
4.00 E-04 \\
9.50 E-05 \\
3.00 E-04 \\
4.00 E-04 \\
9.50 E-05\end{array}$ \\
\hline
\end{tabular}

FOOTNOTES: (1) Effective radioactive decay constant in plume; set to zero if less than $1.0 \mathrm{E}-2$

(2) Fraction of animal's daily intake of nuclide which appears in each $L$ of milk (days $/ L$ )

(3) Fraction of animal's daily intake of nuclide which appears in each $\mathrm{kg}$ of meat (days $/ \mathrm{kg}$ ) 
Jan 19, $1994 \quad 10: 27$ am

GENERAL

Page 3

VALUES FOR RADIONUCLIDE-DEPENDENT PARAMETERS

\begin{tabular}{|c|c|c|c|c|c|}
\hline \multirow[b]{2}{*}{ Nuclide } & & \multicolumn{2}{|c|}{$\begin{array}{l}\text { CONCENTRATION } \\
\text { UPTAKE FACTOR }\end{array}$} & \multicolumn{2}{|c|}{ GI UPTAKE FRACTION } \\
\hline & & Forage (1) & Edible (2) & Inhalation & Ingestion \\
\hline $\begin{array}{l}A M-241 \\
C E-144 \\
P R-144 \\
C O-60 \\
C S-134 \\
C S-137 \\
B A-137 M \\
H-3 \\
K-40 \\
M N-54 \\
P U-238 \\
P U-239 \\
P U-241 \\
R U-106 \\
R H-106 \\
S B-125 \\
T E-125 M \\
S R-90 \\
Y-90 \\
U-235 \\
T H-231 \\
U-238 \\
T H-234 \\
P A-234 \\
U-234 \\
T H-230 \\
R A-226 \\
R N-222 \\
P 0-218 \\
P B-214 \\
B I-214 \\
P O-214 \\
P B-210 \\
B I-210 \\
P O-210\end{array}$ & & $\begin{array}{l}5.50 E-03 \\
1.00 E-02 \\
1.00 E-02 \\
2.00 E-02 \\
8.00 E-02 \\
8.00 E-02 \\
1.50 E-01 \\
0.00 E+00 \\
1.00 E+00 \\
2.50 E-01 \\
4.50 E-04 \\
4.50 E-04 \\
4.50 E-04 \\
7.50 E-02 \\
1.50 E-01 \\
2.00 E-01 \\
2.50 E-02 \\
2.50 E+00 \\
1.50 E-02 \\
8.50 E-03 \\
8.50 E-04 \\
8.50 E-03 \\
8.50 E-04 \\
2.50 E-03 \\
8.50 E-03 \\
8.50 E-04 \\
1.50 E-02 \\
0.00 E+00 \\
2.50 E-03 \\
4.50 E-02 \\
3.50 E-02 \\
2.50 E-03 \\
4.50 E-02 \\
3.50 E-02 \\
2.50 E-03\end{array}$ & $\begin{array}{l}1.07 E-04 \\
1.71 E-03 \\
1.71 E-03 \\
3.00 E-03 \\
1.28 E-02 \\
1.28 E-02 \\
6.42 E-03 \\
0.00 E+00 \\
2.35 E-01 \\
2.14 E-02 \\
1.93 E-05 \\
1.93 E-05 \\
1.93 E-05 \\
8.56 E-03 \\
1.71 E-02 \\
1.28 E-02 \\
1.71 E-03 \\
1.07 E-01 \\
2.57 E-03 \\
1.71 E-03 \\
3.64 E-05 \\
1.71 E-03 \\
3.64 E-05 \\
1.07 E-04 \\
1.71 E-03 \\
3.64 E-05 \\
6.42 E-04 \\
0.00 E+00 \\
1.71 E-04 \\
3.85 E-03 \\
2.14 E-03 \\
1.71 E-04 \\
3.85 E-03 \\
2.14 E-03 \\
1.71 E-04\end{array}$ & $\begin{array}{l}1.00 E-03 \\
3.00 E-04 \\
3.00 E-04 \\
5.00 E-02 \\
9.50 E-01 \\
9.50 E-01 \\
1.00 E-01 \\
9.50 E-01 \\
9.50 E-01 \\
1.00 E-01 \\
1.00 E-03 \\
1.00 E-04 \\
1.00 E-03 \\
5.00 E-02 \\
5.00 E-02 \\
1.00 E-02 \\
2.00 E-01 \\
3.00 E-01 \\
1.00 E-04 \\
2.00 E-03 \\
2.00 E-04 \\
2.00 E-03 \\
2.00 E-04 \\
1.00 E-03 \\
2.00 E-03 \\
2.00 E-04 \\
2.00 E-01 \\
0.00 E+00 \\
1.00 E-01 \\
2.00 E-01 \\
5.00 E-02 \\
1.00 E-01 \\
2.00 E-01 \\
5.00 E-02 \\
1.00 E-01\end{array}$ & $\begin{array}{r}1.00 E-03 \\
3.00 E-04 \\
3.00 E-04 \\
3.00 E-01 \\
9.50 E-01 \\
-9.50 E-01 \\
1.00 E-01 \\
9.50 E-01 \\
9.50 E-01 \\
1.00 E-01 \\
1.00 E-03 \\
1.00 E-03 \\
1.00 E-03 \\
5.00 E-02 \\
5.00 E-02 \\
1.00 E-01 \\
2.00 E-01 \\
3.00 E-01 \\
1.00 E-04 \\
2.00 E-01 \\
2.00 E-04 \\
2.00 E-01 \\
2.00 E-04 \\
1.00 E-03 \\
2.00 E-01 \\
2.00 E-04 \\
2.00 E-01 \\
0.00 E+00 \\
1.00 E-01 \\
2.00 E-01 \\
5.00 E-02 \\
1.00 E-01 \\
2.00 E-01 \\
5.00 E-02 \\
1.00 E-01\end{array}$ \\
\hline OOTNOTES: & (1) & \multicolumn{4}{|c|}{$\begin{array}{l}\text { Concentration factor for uptake of nuclide from soil for } \\
\text { pasture and forage (in } \mathrm{pCi} / \mathrm{kg} \text { dry weight per } \mathrm{pCi} / \mathrm{kg} \text { dry soil) } \\
\text { Concentration factor for uptake of nuclide from soil by edible } \\
\text { parts of crops (in } \mathrm{pC} i / \mathrm{kg} \text { wet weight per } \mathrm{pC} i / \mathrm{kg} \text { dry soil) }\end{array}$} \\
\hline
\end{tabular}

H-3 DOSE CONVERSION FACTOR FOR WATER INGESTION $(\mathrm{rem}-\mathrm{cc} / \mathrm{pC} \mathrm{i}-\mathrm{y}): \quad 5.70 \mathrm{E}-02$ 
Jan 19, $1994 \quad 10: 27$ am

GENERAL

Page 4

DECAY CHAIN INGROWTH FACTORS

\begin{tabular}{|c|c|c|}
\hline Nuclide & Parent (s) & Ingrowth Factor $(s)$ \\
\hline $\begin{array}{l}\text { BA-137M } \\
\text { PA-234 } \\
\text { RA-226 } \\
\text { PB-214 } \\
\text { BI-214 } \\
\text { PO-210 }\end{array}$ & $\begin{array}{l}\text { CS-1.37 } \\
T H-234 \\
T H-230 \\
T H-230 \\
\text { RA-226 } \\
\text { PO-218 } \\
T H-230 \\
\text { RA-226 } \\
\text { PO-218 } \\
\text { PB-214 } \\
\text { PB-210 } \\
\text { BI-210 }\end{array}$ & $\begin{array}{l}3.209 \mathrm{E}+06 \\
2.961 \mathrm{E}+04 \\
1.490 \mathrm{E}-02 \\
6.915 \mathrm{E}+03 \\
4.635 \mathrm{E}+05 \\
1.138 \mathrm{E}-01 \\
9.313 \mathrm{E}+03 \\
6.240 \mathrm{E}+05 \\
1.532 \mathrm{E}-01 \\
1.347 \mathrm{E}+00 \\
3.560 \mathrm{E}+01 \\
3.621 \mathrm{E}-02\end{array}$ \\
\hline
\end{tabular}


HUMAN INHALATION RATE

Cubic centimeters/hr

$9.17 E+05$

SOIL PARAMETERS

Effective surface density ( $\mathrm{kg} / \mathrm{sq} \mathrm{m}$, dry weight)

(Assumes $15 \mathrm{~cm}$ plow layer)

2. $15 E+02$

BUILDUP TIMES

For activity in soil (years)

For radionuclides deposited on ground/water (days)

$-1.00 E+02$

$3.65 \mathrm{E}+04$

DELAY TIMES

Ingestion of pasture grass by animals ( $h r$ )

Ingestion of stored feed by animals (hr)

Ingestion of leafy vegetables by man ( $h r$ )

Ingestion of produce by man (hr)

Transport time from animal feed-milk-man (day)

Time from slaughter to consumption (day)

$0.00 E+00$

2. $16 \mathrm{E}+03$

3. $36 \mathrm{E}+02$

$3.36 E+02$

$2.00 E+00$

2. $00 E+01$

WEATHERING

Removal rate constant for physical loss (per hr)

$2.90 E-03$

CROP EXPOSURE DURATION

Pasture grass (hr)

Crops/leafy vegetables (hr)

$7.20 E+02$

$1.44 E+03$

AGRICULTURAL PRODUCTIVITY

Grass-cow-milk-man pathway ( $\mathrm{kg} / \mathrm{sq} \mathrm{m}$ )

Produce/leafy veg for human consumption $(\mathrm{kg} / \mathrm{sq} \mathrm{m})$

2.80E-01

$7.16 E-01$

FALLOUT INTERCEPTION FRACTIONS

Vegetables

2.00E-01

Pasture

$5.70 E-01$

GRAZING PARAMETERS

Fraction of year animals graze on pasture

Fraction of daily feed that is pasture grass

when animal grazes on pasture

4.00E-01

4.30E-01 
ANIMAL FEED CONSUMPTION FACTORS

Contaminated feed/forage ( $\mathrm{kg} /$ day, dry weight)

$1.56 E+01$

DAIRY PRODUCTIVITY

Milk production of cow (L/day)

1. $10 E+01$

MEAT ANIMAL SIAUGHTER PARAMETERS

Muscle mass of animal at slaughter $(\mathrm{kg})$

Fraction of herd slaughtered (per day)

$2.00 E+02$

$3.81 E-03$

DECONTAMINATION

Fraction of radioactivity retained after washing

for leafy vegetables and produce

$5.00 E-01$

FRACTIONS GROWN IN GARDEN OF INTEREST

Produce ingested

Leafy vegetables ingested

$1.00 E+00$

$1.00 E+00$

INGESTION RATIOS:

IMMEDIATE SURROUNDING AREA/TOTAL WITHIN AREA

Vegetables

Meat

$1.00 E+00$

Milk

$1.00 E+00$

$1.00 E+00$

MINIMUM INGESTION FRACTIONS FROM OUTSIDE AREA

(Minimum fractions of food types from outside

area listed below are actual fixed values.)

Vegetables

$0.00 E+00$

Meat

$0.00 E+00$

Milk

$0.00 E+00$

HUMAN FOOD UTILIZATION FACTORS

Produce ingestion $(\mathrm{kg} / \mathrm{y})$

$1.76 E+02$

Milk ingestion $(L / y)$

Meat ingestion $(\mathrm{kg} / \mathrm{y})$

$1.12 E+02$

Leafy vegetable ingestion $(\mathrm{kg} / \mathrm{y})$

$8.50 E+01$

$1.80 E+01$

SWIMMING PARAMETERS

Fraction of time spent swimming $\quad 0.00 E+00$

Dilution factor for water $(\mathrm{cm})$

$1.00 E+00$ 
DOE/RL-94-15, Rev. 0

\section{DISTRIBUTION}

Number of copies

ONSITE

U.S. Department of Energy-

Richland Operations office

5

J. P. Collins

S. D. Stites

H. R. Trumble

Public Reading Room (2)

A5-19

A5-15

A5-19

A1-65

1

Pacific Northwest Laboratory

20

Westinghouse Hanford Company

J. A. Bates

D. J. Carrel1

E. T. Coenenberg

B. L. Curn

L. P. Diediker

J. H. Dunkirk

R. J. Gimera

M. C. Hughes

J. J. Luke

M. R. Morton

V. J. Rice

D. L. Schilperoort

J. L. Walsh

Central files

EPIC (3)

H6-22

H6-22

H6-25

T1-30

T1-30

B3-06

$\times 0-57$

$\times 5-55$

H6-25

R2-77

$\times 8-25$

$X 0-19$

$\times 0-57$

L8-04

Information Release Administration (3) $\begin{array}{r}\mathrm{H6}-08 \\ \mathrm{H} 4-17\end{array}$ 


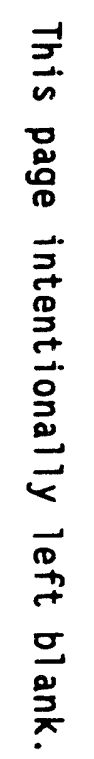

芠 

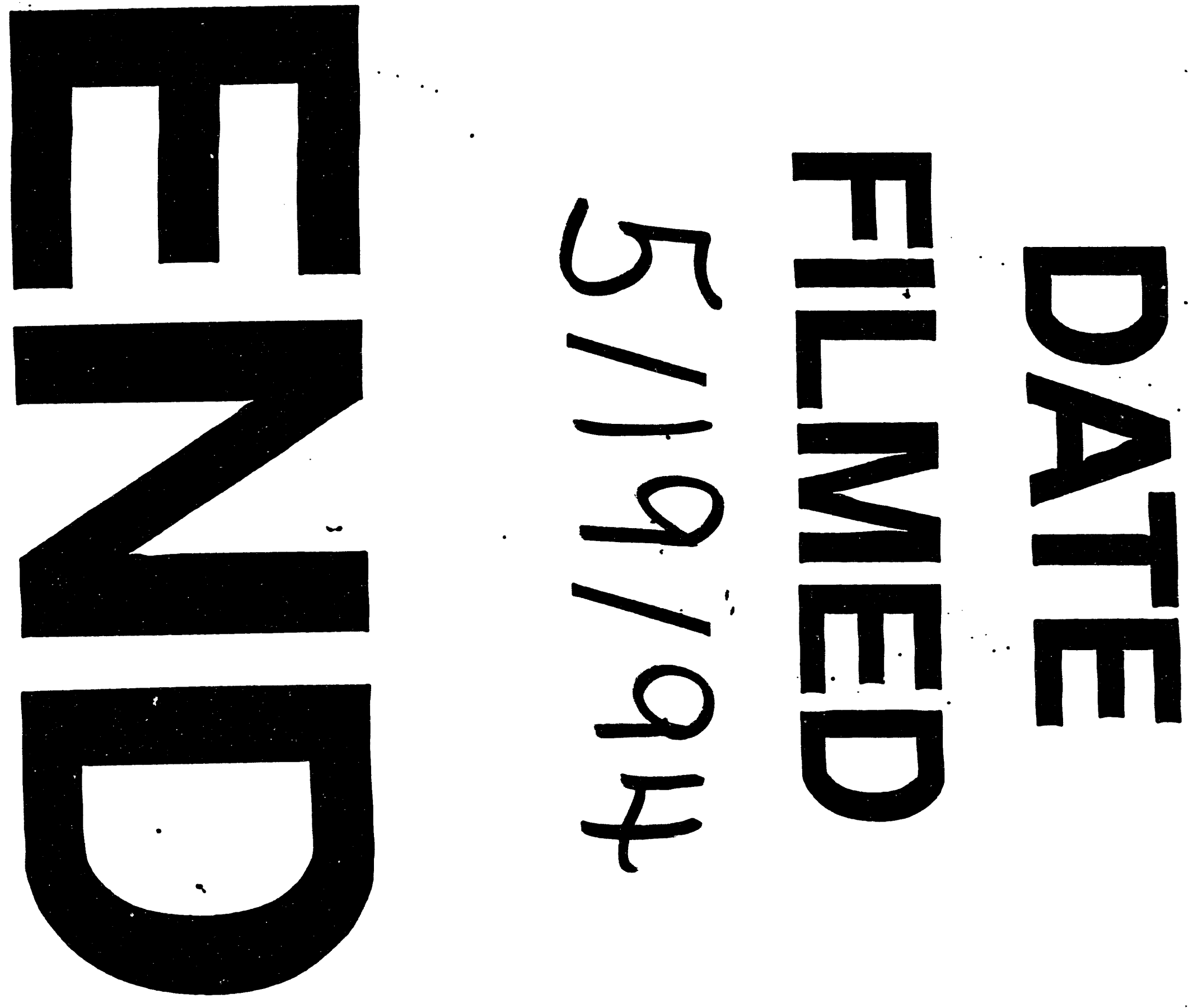
